\title{
CAML ACBM
}

\section{CAML REVIEW / REVUE DE L'ACBM}

VoL. 47 , NO. 2-3

AuGUST-NOVEMBER / AOÛT-NOVEMBRE 2019

\section{Reports, News, Essays / Rapports, nouvelles, essais}

Message from the President / Message du président

Houman Behzadi

Call for applications: CAML Review editorial positions / Appel de mise en candidature : Revue de l'ACBM, postes au sein de l'équipe de rédaction

CAML Conference 2019: Program and Abstracts /

Congrès de l'ACBM 2019 : Programme du congrès et résumés de communications

Cataloguing Committee: Annual Report at CAML 2019

Daniel Paradis

Minutes of the 2018 CAML/ACBM Annual General Meeting

Stu Davis: Canada's Cowboy Troubadour

Brock Silversides

\section{Reviews / Comptes rendus}

Analytical Essays on Music by Women Composers: Secular and Sacred Music to 1900 - edited by Laurel Parsons and Brenda Ravenscroft (Book) / Roxane Prevost

Buffy Sainte-Marie: The Authorized Biography - by Andrea Warner (Book) / Monique Giroux

Classical Music: Expect the Unexpected - by Kent Nagano with Inge Kloepfer (Book) / Elaine Keillor

Debussy's Resonance - edited by François de Médicis and Steven Huebner (Book) / Edward Jurkowski

From Scratch: Writings in Music Theory - by James Tenney (Book) / Lelland Reed

Lire, écouter, écrire : Initiation à la recherche en musique à partir des méthodes des sciences humaines - de

The Pop Palimpsest: Intertextuality in Recorded Popular Music - edited by Lori Burns and Serge Lacasse (Book) / Stephanie Bonjack 
CAML Review, published three times a year, is the official publication of the Canadian Association of Music Libraries, Archives and Documentation Centres. CAML Review welcomes submissions of research articles (peer-reviewed section), reports, news, essays, and reviews on topics relevant to the purposes of the Association, particularly those pertaining to music in Canada, music librarianship and archival management, and bibliography. Author guidelines can be consulted on the journal site.

La Revue de l'ACBM, publiée trois fois l'an, est l'organe officiel de l'Association canadienne des bibliothèques, archives et centres de documentation musicaux. La Revue de l'ACBM vous invite à lui soumettre des articles de recherche (pour la section d'articles évalués par des pairs), des rapports, des nouvelles, des essais et des comptes rendus portant sur des sujets pertinents aux objectifs de I'Association, en particulier ceux qui traitent de la musique au Canada, de la bibliothéconomie et la gestion d'archives de la musique, ainsi que la bibliographie. On peut lire les directives aux auteurs sur le site de la Revue.

Editor / Rédactrice en chef :

Cathy Martin, Marvin Duchow Music Library, McGill University, Montreal, Quebec, H3A 1 E3.

Tel: 514-398-5874; cathy.martin@mcgill.ca

Associate Editors / Rédactrices adjointes :

Megan Chellew, Collection Services, McGill University Library, Montreal, Quebec, H3A OC9.

Tel: 514-398-4174; megan.chellew@mcgill.ca

Deborah Wills, Librarian Emeritus, Wilfrid Laurier University, Waterloo, Ontario; dwills@wlu.ca

Review Editor / Responsable des comptes-rendus :

Brian C. Thompson, Department of Music, The Chinese University of Hong Kong, Shatin, NT, Hong Kong SAR, China. Tel: 852-3943-4220; thompson@cuhk.edu.hk

CAML Membership Secretary / Secrétaire aux adhesions de l'ACBM :

Becky Smith, Music Resource Centre, Memorial University of Newfoundland, St John's, Newfoundland, A1C 5S7. Tel: 709-864-7829; becky.smith@mun.ca

Advertising / Publicité : Please contact the Editors. / Veuillez communiquer avec les rédacteurs.

CAML Review / Revue de l'ACBM : $\underline{\text { http://caml.journals.yorku.ca }}$

CAML / ACBM : https://www.caml-acbm.org

Section québécoise de I'ACBM / Quebec Chapter of CAML : http://www.sqacbm.org

(C) 2019 Canadian Association of Music Libraries, Archives and Documentation Centres / Association canadienne des bibliothèques, archives et centres de documentation musicaux 


\title{
Message from the President
}

\author{
Houman Behzadi
}

\section{Message du président (lien vers la version française)}

\begin{abstract}
My Journey
What an honour to serve the Canadian Association of Music Libraries, Archives and Documentation Centres! And what a privilege to write to you as its President! It was nearly eighteen years ago when I first walked into a music library, on my first day as an international student in Canada. I remember the crescendo of excitement with each step I took from the library gates to the service desk, behind which - I was told enthusiastically by a library staff member-lived 18,000 CDs, available to borrow! Tears of joy ran down my face as I looked at the collection in utter disbelief; I could not believe that I was granted access to a carefully curated collection of sound recordings! In hindsight, I know I was experiencing democracy firsthand, and in that particular way for the first time: Music available to all! Music information in many formats collected, preserved, and made accessible to people, to me. On that September morning in 2001, the work of music information professionals, manifested by their curated ecosystem, changed my life. Today, I still feel the same thrill as I walk to work every day; work I shall never take for granted, and joy that I am fortunate to share with you, my fellow CAML members. It is therefore with great hope and optimism that I begin this mandate. Thank you for your support as we navigate forward together!
\end{abstract}

\section{CAML Board Changes}

This year, the CAML Board welcomed two new members: Marc Stoeckle (University of Calgary) is our new Communications Officer, taking over from James Mason (University of Toronto); and Lucinda Johnston (University of Alberta), our new Secretary, succeeds Katherine Penner (University of Manitoba). We are grateful to James and Katherine for their contributions to CAML. I also wish to acknowledge our Past President Carolyn Doi who led the Association with enthusiasm and accomplished a great deal over the last two years. Under her leadership, the CAML Board updated the Association's Procedures Manual, a document that is instrumental to our governance. Carolyn's advocacy for diversity, and her efforts to raise awareness about important topics such as decolonization of libraries and the Truth and Reconciliation Commission of Canada's Final Report are indeed commendable. I have been benefitting from her knowledge and guidance and look forward to our continued collaboration on the CAML Board, and beyond. In the upcoming months, our new Nominations Officer, Kyla Jemison (University of Toronto), will begin her work towards the election of CAML's President-Elect.

\section{IAML News}

In July, I attended IAML Congress 2019 in Krakow, Poland. The Congress program was varied with an emphasis on the music, music libraries, and archives of Poland. Our hosts exhibited memorable generosity and the Jagiellonian University provided an ideal venue. I invite you to review the Congress materials and diaries as there is much to consult and appreciate. On Tuesday, July 16, I attended the Forum of National Representatives where we discussed issues concerning IAML's twenty-six national branches. Two important items are worthy of your attention: 1) The increase, in 
2021, of membership fees from 43 to 44 euros for individual members and from 72 to 74 euros for institutions (see the General Assembly minutes); and 2) Going forward, all individual Fontes subscriptions will be electronic-only by default. CAML/IAML members who wish to continue receiving print copies are welcome to do so by requesting print via their personal IAML account.

\section{CAML Annual Conference: London, June 4-5, 2020}

Preparations for our next annual conference are well underway. We will come together on Thursday and Friday, June 4-5, 2020, at the Don Wright Faculty of Music, Western University and will be meeting in conjunction with the Canadian University Music Society (MusCan) under the umbrella of the Congress of the Humanities and Social Sciences 2020. I look forward to returning to my alma mater, and how fortunate we are to visit the Western University Music Library and its treasures! The Music Library at Western is internationally recognized for its rare and special collections, including the Gustav Mahler-Alfred Rosé, Cherubini, and Drs. James and Margaret Whitby collections. Brian McMillan, Director of Western Music Library and former CAML President, is our Local Organizer and Alastair Boyd (Librarian Emeritus, University of Toronto), our Program Committee Chair. I am certain that the London meeting will be a very special occasion for our Association and I encourage you all to participate and take full advantage of the CAML, MusCan, and Congress offerings.

\section{CAML Awards}

This year is also special in that we are offering four awards, three of which support attendance and participation at our 2020 conference. We are also offering a Research and Professional Development Scholarship that can be used to attend conferences or to support a research project. You can certainly help us spread the word about these great opportunities by promoting them to eligible candidates at your institutions, or by informing music and/or information studies graduate students in your cities and provinces.

\section{CAML Renewal Task Force}

Since joining CAML in 2014, I have listened carefully to the membership's concerns with regards to the decreasing number of members and reduced participation at our annual meetings. This, of course, is not unique to CAML; the Music Library Association (MLA) has expressed similar concerns. We are a much smaller group, so the trend is more visible. As mentioned during the 2019 AGM in Vancouver, and via a recent communication to the listserv, I believe the time has come, once again, to engage in a strategic planning exercise for the Association. In fact, I have made this my top priority as I believe we need to come together to review, and-as necessary-renew our directions. To this end, shortly after the Vancouver meeting, I put forward a proposal to the Board to form the CAML Renewal Task Force, a group of three appointed and two elected members-and myself as ex officio-who will lead a 2-year charge to perform an environmental scan followed by a strategic planning exercise. The ultimate goal of the Task Force is to present the membership with several options for our future directions. The membership will then vote to choose the future direction(s), be it the status quo or a fundamental change to our governance. I wish to thank Jan Guise (University of Toronto), Rachel Gagnon (Library and Archives Canada), Scott Cowan (University of Windsor), Sean Luyk (University of Alberta), and Brian McMillan for joining me to carry out this 
important work. We will have our first Task Force meeting in the upcoming days and will provide a progress report during the 2020 meeting in London.

\section{New CAML Website}

In this period of renewal, I am very happy to see CAML's new website up and running! The new platform, exhibiting our new logo, has a fresh look and shows great potential for communicating the important information of our Association. The Board will continue to work on enhancing the site's content, with the goal of having everything in place by the 2020 annual conference. A fine feature of the site is the incorporation of the CAML Review platform, allowing users to access the journal site directly from the website. This is an innovative measure bringing together these two important communication vehicles of the Association. Marc Stoeckle has spearheaded the website initiative and will manage it during his term on the Board. I am grateful to Marc, and to James Mason for his work on the former site.

\section{CAML Review Editorial Openings}

We are indebted to Cathy Martin (McGill University) for her ten years of service as CAML Review Editor. Anyone who has ever worked with Cathy, or published in the Association's journal, knows of her dedication to this work. Her contributions have significantly raised the impact of our Association; under her leadership, CAML Review added a peer-review section, a substantial achievement for music librarianship in Canada! For me, what distinguishes Cathy is her ongoing commitment to mentorship for authors at all stages of their careers. On behalf of the entire Association, I wish to express my gratitude to Cathy for her remarkable accomplishments! Cathy will step down from her position at the end of this calendar year. Brian Thompson (The Chinese University of Hong Kong), our Review Editor, will step down at the same time, after 3 years of service in this position. I am thankful to Brian, and to our Associate Editors, Deborah Wills (Librarian Emerita, Wilfrid Laurier University) and Megan Chellew (McGill University), for their work on the journal. Unfortunately, the Board's efforts to replace Cathy and Brian have been unsuccessful so far. As we continue our search for their replacements, I wish to ask all of you to help us, either by stepping forward or by identifying individuals who might be interested in carrying the torch. Please contact Cathy Martin if you wish to know more about the associated charges.

\section{CAML Cataloguing Committee}

Last but not least, I wish to thank Daniel Paradis (Bibliothèque et Archives nationales du Québec) for chairing the CAML Cataloguing Committee since 2003. Over the past sixteen years, Daniel has shared his expert knowledge with the CAML community, and has represented the Association on many national and international forums concerned with cataloguing, metadata, and evolving descriptive practices. Going forward, Megan Chellew and Andrew Senior (McGill University) have graciously agreed to co-chair the CAML Cataloguing Committee. At a recent meeting with both of them, I was very pleased to learn about their plans to build a virtual community of practice for CAML, taking advantage of the new website to share cataloguing resources pertinent to the work of music information professionals in Canada. 


\section{Québec Chapter of CAML}

I was fortunate to attend the annual meeting of the Québec Chapter of CAML (SQACBM), held on Friday, November 22 at the Webster Library of Concordia University. The Chapter continues to thrive, bringing together many professionals and students at its annual daylong meeting.

\section{Conclusion}

Once again, I thank you all for your continued interest in CAML and its activities. I look forward to seeing many of you at various national or international meetings, and, most importantly, on June 45, 2020, in London, Ontario!

I wish you continued success in your work and endeavours!

Houman Behzadi

CAML President

houman.behzadi@mcgill.ca

\section{Message du président}

\section{Houman Behzadi}

\section{Message from the President (link to English version)}

\section{Mon cheminement}

Je suis honoré de servir l'Association canadienne des bibliothèques, archives et centres de documentation musicaux! Quel privilège aussi de vous écrire en qualité de président de cette association! II y a presque dix-huit ans, je suis entré pour la première fois dans une bibliothèque de musique lors de ma première journée de cours en tant qu'étudiant international au Canada. Je me rappelle le crescendo de ravissement que j'ai ressenti à mesure que je me déplaçais de la porte jusqu'au comptoir de service. Un employé de la bibliothèque m'a annoncé avec enthousiasme que ce lieu recelait $18000 \mathrm{CD}$, et que je pouvais les emprunter! Des larmes de joie ont inondé mes joues tandis que je contemplais cette collection avec incrédulité. Je n'arrivais pas à croire que l'on m'accordait l'accès à une collection soigneusement choisie d'enregistrements sonores! En rétrospective, je comprends maintenant que je faisais pour la première fois l'expérience de la démocratie, de cette manière. La musique accessible à tous! Une information musicale sur de nombreux supports, collectionnée, préservée et rendue accessible à tous, à moi! Ce matin de septembre 2001, le travail des professionnels de l'information musicale ainsi que leur écosystème bien organisé ont changé ma vie. Je ressens toujours le même enthousiasme quand je me rends chaque jour au travail. Je ne tiendrai jamais mon travail pour acquis et je suis heureux de partager le bonheur que j'éprouve à l'accomplir avec vous, les membres de l'ACBM. J'entame donc mon mandat de président avec beaucoup d'espoir et d'optimisme. Merci de me soutenir au cours de notre cheminement collectif! 
Changements au CA de l'ACBM

Cette année, le CA de l'ACBM a accueilli deux nouveaux membres : Marc Stoeckle (Université de Calgary) devient notre nouveau directeur des communications et remplace James Mason (Université de Toronto); Lucinda Johnston (Université de l'Alberta) prend la place de la secrétaire Katherine Penner (Université du Manitoba). Nous remercions James et Katherine pour les services qu'ils ont rendus à l'ACBM. Je remercie également l'ancienne présidente Carolyn Doi pour sa direction enthousiaste et tout le travail qu'elle a accompli durant son mandat de deux ans. Sous son leadership, le CA de l'ACBM a actualisé son manuel de procédures, un document essentiel à sa gouvernance. Carolyn mérite des éloges pour sa promotion de sujets importants comme la diversité ainsi que pour les efforts qu'elle a déployés dans le but de sensibiliser les membres à la décolonisation des bibliothèques et au rapport final de la Commission de vérité et réconciliation du Canada. J'ai tiré profit de ses connaissances et de ses conseils, et je me réjouis de continuer de collaborer avec elle au sein du CA et ailleurs. Au cours des mois prochains, notre nouvelle responsable des mises en candidature, Kyla Jemison (Université de Toronto), entamera le processus relatif à l'élection du nouveau président désigné de l'ACBM.

\section{Nouvelles de l'AIBM}

En juillet, je me suis rendu au congrès de l'AIBM à Cracovie, en Pologne. Le programme varié mettait l'accent sur la musique, les bibliothèques de musique et les archives de Pologne. Nos hôtes se sont montrés incroyablement généreux, et l'Université Jagiellonian constituait l'endroit idéal pour y tenir un tel événement. Je vous invite à lire la documentation afférente au congrès ainsi que le journal de bord du congrès, car vous y trouverez beaucoup de renseignements utiles. Le mardi 16 juillet, j'ai assisté au forum des représentants nationaux. Nous y avons discuté de questions relatives aux vingt-six sections de l'AIBM. Deux sujets sont particulièrement dignes d'attention. D'abord, en 2021, les droits d'adhésion passeront de 43 à 44 euros pour les membres individuels et de 72 à 74 euros pour les établissements membres (voir le procès-verbal de l'assemblée générale). Ensuite, tous les abonnements à Fontes deviendront électroniques par défaut. Les membres de I'ACBM ainsi que de l'AIBM souhaitant en recevoir des exemplaires papier peuvent en faire la demande au moyen de leur compte d'utilisateur de l'AIBM.

\section{Conférence annuelle de l'ACBM à London, Ontario, les 4 et 5 juin 2020}

Les préparatifs relatifs à notre conférence annuelle vont bon train. Nous nous réunirons les jeudi et vendredi 4 et 5 juin 2020 à la faculté de musique Don Wright de l'Université Western, avec la Société de musique des universités canadiennes (MusCan), lors du Congrès 2020 des sciences humaines. L'idée de retourner à mon alma mater m'enthousiasme! Quel privilège de visiter la bibliothèque de musique de l'Université Western pour y découvrir ses trésors! Celle-ci jouit d'une réputation internationale en raison de ses collections rares et spéciales, y compris les collections Gustav Mahler-Alfred Rosé, Cherubini et James et Margaret Whitby. Brian McMillan, directeur de la bibliothèque de musique de l'Université Western et ancien président de l'ACBM, est responsable des préparatifs sur place, tandis qu'Alastair Boyd (bibliothécaire émérite de l'Université de Toronto) préside le comité de programme. Je suis convaincu que le congrès de London revêtira une signification particulière pour notre association. Je vous encourage donc à y participer et à vous prévaloir de ce qui sera présenté aux congrès de l'ACBM, de MusCan et de la Fédération des sciences humaines. 


\section{Prix de l'ACBM}

Cette année est exceptionnelle en ce sens que nous remettrons quatre prix, dont trois visant à encourager la présence et la participation des membres à la conférence de 2020 . Nous offrons également une Bourse de recherche et de perfectionnement professionnel que le gagnant pourra utiliser pour se rendre à des congrès ou encore pour financer un projet de recherche. Aidez-nous à faire connaître ces prix en en parlant à des candidats admissibles de votre établissement ou en en faisant part aux étudiants des cycles supérieurs en musique ou en sciences de l'information de votre ville et de votre province.

\section{Groupe de travail visant le renouveau de l'ACBM}

Depuis que je me suis joint à l'ACBM en 2014, j'ai été attentif aux préoccupations exprimées par les membres quant à la diminution du nombre d'adhésions et à la faible participation aux rencontres annuelles. Cette réalité n'est pas unique à l'ACBM; la Music Library Association (MLA) déplore la même chose. Étant donné que nous sommes beaucoup moins nombreux que les membres de la MLA, cette tendance est plus évidente. Comme nous en avons discuté, à la fois durant l'AGA 2019 tenue à Vancouver et plus récemment au moyen de notre serveur de liste, je crois que le moment est venu, une fois de plus, d'entreprendre une planification stratégique. Du reste, j'en ai fait ma priorité, car je pense que nous devons nous réunir pour réviser nos directives et, si nécessaire, les rénover. À cette fin, peu de temps après I'AGA de Vancouver, j'ai proposé au CA d'organiser un groupe de travail visant le renouveau de l'ACBM, formé de deux membres élus et de trois personnes nommées (je suis désigné d'office). Ce groupe est chargé, sur une période de deux ans, de procéder à une analyse du contexte, puis de planifier une stratégie à adopter. II a pour but ultime de présenter aux membres plusieurs options quant à la direction à emprunter à l'avenir. Les membres voteront ensuite sur l'orientation à donner à l'association, qu'il s'agisse d'adhérer au statu quo ou d'opérer une transformation complète de la gouvernance. Je remercie Janneka Guise (Université de Toronto), Rachel Gagnon (Bibliothèque et Archives Canada), Scott Cowan (Université de Windsor), Sean Luyk (Université de l'Alberta) et Brian McMillan de se joindre à moi pour réaliser ce projet important. Nous nous réunirons au cours des prochains jours et fournirons un rapport d'étape aux membres lors de la conférence 2020 de London.

\section{Nouveau site Web de l'ACBM}

En parlant de renouveau, je suis heureux de constater que le nouveau site Web de l'ACBM est opérationnel. La plateforme de même que notre logo ont un nouveau look, et le site promet d'être un outil essentiel pour transmettre des renseignements relatifs à l'association. Le CA poursuivra le peaufinage du site; il se donne pour but d'avoir terminé cette tâche d'ici la conférence de 2020. L'onglet Publication permet aux utilisateurs d'avoir directement accès à la Revue de l'ACBM à partir du site Web, une belle fonctionnalité. Voilà une idée novatrice qui réunit deux outils importants de communication pour l'association. Marc Stoeckle a mené cette initiative et il continuera de la diriger durant son mandat au sein du CA. Je le remercie pour ses efforts, de même que James Mason, pour le travail qu'il a effectué sur l'ancien site.

\section{Postes vacants au sein de l'équipe de rédaction de la Revue de l'ACBM}

Nous sommes redevables à Cathy Martin (Université McGill) pour les dix années qu'elle a consacrées à la Revue de l'ACBM en tant que rédactrice en chef. Tous ceux qui ont travaillé avec 
Cathy ou qui ont fait paraître des écrits dans la Revue connaissent son engagement pour la cause. Par sa collaboration, elle a beaucoup étendu l'influence de notre association; sous sa direction, la Revue de l'ACBM a gagné une section d'articles révisés par des pairs, un jalon important pour la bibliothéconomie de la musique au Canada! Ce qui distingue Cathy des autres, selon moi, c'est son engagement à servir de mentor à des auteurs qui en sont à divers stages de leur carrière. Au nom de toute l'association, je tiens à exprimer ma reconnaissance à Cathy pour ses réalisations hors pair! Cathy quittera ses fonctions à la fin de l'année 2019. Brian Thompson (The Chinese University of Hong Kong), responsable des comptes rendus, laissera aussi son poste à cette date, après l'avoir occupé durant trois ans. Je remercie Brian, ainsi que nos rédactrices adjointes Deborah Wills (bibliothécaire émérite de l'Université Wilfrid Laurier) et Megan Chellew (Université McGill) pour le travail qu'elles ont accompli. Malheureusement, le CA n'a pas encore réussi à trouver de remplaçants pour Cathy et Brian. Tandis que nous poursuivons nos recherches, j'invite chacun à collaborer avec nous soit en acceptant l'un de ces postes, soit en suggérant le nom de personnes qui seraient prêtes à reprendre le flambeau. Veuillez communiquer avec Cathy Martin pour en savoir davantage sur les responsabilités que comportent ces postes.

\section{Comité de catalogage de l'ACBM}

Enfin, je remercie Daniel Paradis (Bibliothèque et Archives nationales du Québec) d'avoir présidé le comité de catalogage de l'ACBM depuis 2003. Au cours des seize dernières années, Daniel a transmis son expertise à la communauté de l'ACBM et a représenté l'association lors de nombreux forums nationaux et internationaux traitant de catalogage, de métadonnées et de pratiques descriptives en évolution. Megan Chellew et Andrew Senior (Université McGill) ont gracieusement accepté d'être coprésidents du comité de catalogage. Quand je les ai récemment rencontrés, j'ai été très heureux d'apprendre qu'ils entendent créer une communauté virtuelle de praticiens qui profiteraient du nouveau site Web pour s'échanger des ressources de catalogage appropriées au travail des professionnels de l'information musicale au Canada.

\section{Section québécoise de l'ACBM}

J'ai eu le privilège d'assister à la rencontre annuelle 2019 de la Section québécoise de l'ACBM (SQACBM) ayant eu lieu le vendredi 22 novembre à la bibliothèque Webster de l'Université Concordia. Cette section continue de s'épanouir et d'attirer de nombreux professionnels et étudiants à sa réunion d'un jour.

\section{Conclusion}

Une fois de plus, je vous remercie de votre intérêt soutenu pour l'ACBM et ses activités. J'ai hâte de vous rencontrer en grand nombre tant à des événements nationaux qu'internationaux. Surtout, j'espère vous voir à London, en Ontario, les 4 et 5 juin prochains!

Puissent votre travail et vos projets être couronnés de succès!

Houman Behzadi

Président de l'ACBM

houman.behzadi@mcgill.ca 


\section{Call for applications: CAML Review editorial positions}

\section{Appel de mise en candidature : Revue de l'ACBM, postes au sein de l'équipe de rédaction}

The Canadian Association of Music Libraries, Archives and Documentation Centres (CAML) seeks a new Lead Editor and a new Review Editor for its journal, CAML Review.

\section{About CAML Review}

The official publication of CAML/ACBM, $C A M L$ Review is published three times a year and includes research articles (peerreviewed section), reports (including official association business), news, essays, and reviews. Topics covered are relevant to the purposes of the Association, particularly those pertaining to music in Canada, music librarianship, archival management, and bibliography. Reviews of recordings, books, and reference publications focus primarily on Canadian content. The journal includes materials written in either English or French, the two official languages of the Association. CAML Review is an openaccess publication, licensed under a Creative Commons Attribution-Non Commercial 4.0 International License. The journal can be accessed at https://caml.journals.yorku.ca.

\section{Lead Editor}

The primary responsibilities of the Lead Editor, in collaboration with the Review Editor and the Associate Editor(s), are as follows: solicit and manage submissions; coordinate the peer-review process; edit, proofread, and format submissions; arrange for translations as necessary;
L'Association canadienne des bibliothèques, archives et centres de documentation musicaux (ACBM) est à la recherche d'un nouveau rédacteur en chef ou d'une nouvelle rédactrice en chef, ainsi que d'un nouveau ou d'une nouvelle responsable des comptes rendus, pour sa Revue de l'ACBM.

\section{À propos de la Revue de l'ACBM}

Publication officielle de l'ACBM/la CAML, la Revue de l'ACBM paraît trois fois l'an et comprend des articles de recherche (évalués par les pairs), des rapports (y compris des rapports administratifs), des nouvelles, des essais, ainsi que des comptes rendus traitant de sujets qui correspondent aux objectifs de l'Association, en particulier ce qui concerne la musique au Canada, la bibliothéconomie de la musique, le traitement des archives et la bibliographie. Les comptes rendus d'enregistrements, de livres et d'ouvrages de référence portent surtout sur du contenu canadien. La Revue de l'ACBM est rédigée en français et en anglais, les deux langues officielles de l'Association, et est une publication en libre accès, autorisée par la Creative Commons Attribution - Pas d'utilisation commerciale 4.0 International. On peut accéder à la Revue en se rendant à l'adresse : https://caml.journals.yorku.ca

\section{Rédacteur en chef ou rédactrice en chef}

Travaillant de concert avec le ou la responsable des comptes rendus ainsi que le(s) rédacteur(s) adjoint(s) et la ou le(s) rédactrice(s) adjointe(s), le rédacteur en chef ou la rédactrice en chef a pour fonctions 
post issues online (Open Journal Systems); disseminate information to members about each newly available issue; and maintain "About the Journal" documentation (e.g. Author Guidelines) on the journal's website. As the journal includes content in both English and French, knowledge of both languages would be an asset.

\section{Review Editor}

The responsibilities of the Review Editor include identifying publications for review (with priority given to Canadian content), liaising with review authors, and editing submissions. As the journal includes content in both English and French, knowledge of both languages is an asset.

Applications for the positions should be accompanied by a letter of intent and current curriculum vitae. Please send these via email, along with any questions, to CAML President Houman Behzadi (houman.behzadi@mcgill.ca). Applications will be accepted until the positions are filled. d'inviter et de gérer les soumissions; de coordonner le processus d'évaluation par les pairs; de réviser, de relire et de formater les soumissions; de demander qu'un texte soit traduit, au besoin; d'afficher les numéros en ligne (système Open Journal); d'informer les membres de la parution d'un nouveau numéro et de réunir la documentation paraissant à l'onglet « À propos de la Revue » (p. ex. : les directives aux auteurs et aux auteures) sur le site Web de la Revue. Comme il s'agit d'une revue bilingue, la connaissance des deux langues est un atout.

\section{Responsable des comptes rendus}

Les fonctions du ou de la responsable des comptes rendus incluent les suivantes : choisir les publications à commenter (en accordant la priorité au contenu canadien), travailler en liaison avec les auteurs et les auteures de comptes rendus et réviser les soumissions. Comme il s'agit d'une revue bilingue, la connaissance des deux langues est un atout.

\section{Les candidatures à ces deux postes doivent} s'accompagner d'une lettre de motivation et d'un curriculum vitae à jour. Veuillez les faire parvenir par courriel, ainsi que toute question, au président de l'ACBM, Houman Behzadi (houman.behzadi@mcgill.ca). Nous accepterons des demandes jusqu'à ce que ces postes soient pourvus. 


\title{
06-07 \\ June/juin 2019
}

\section{MUSIC CONNECTS/ LA MUSIQUE UNIT}

Building a Circle of Relationships Between Universities \& Communities/Rapprocher universités et collectivités

\author{
www.caml-acbm.org
}




\section{MUSIC CONNECTS/ LA MUSIQUE UNIT}

\section{CAML/ACBM 2019 CONFERENCE SCHEDULE / Horaire du Congrès 2019 de l'ACBM / de la CAML}

University of British Columbia, School of Music

Université de la Colombie-Britannique, École de musique

Wednesday, 5 June 2019

Mercredi, 5 juin 2019

3:00 pm - 5:00 pm

$15 \mathrm{~h}-17 \mathrm{~h}$

CAML/ACBM Board Meeting (Room 400B) / Réunion du CA de l'ACBM / de la CAML (Pièce 400B)

\section{Thursday, 6 June 2019}

Jeudi, 6 juin 2019

8:00 am - 9:00 am

$8 h-9 h$

9:00 am - 11:00 am

$9 \mathrm{~h}-11 \mathrm{~h}$

Breakfast \& Registration (Foyer or Room 116) / Petit déjeuner et inscription (Foyer ou pièce 116)

SESSION/SÉANCE I Chair/Prèsidence: Marc Stoeckle | Room/Pièce 116

Early Sound Recordings at Library and Archives Canada / Premiers enregistrements sonores à Bibliothèque et Archives Canada

Margaret Piper | Libraries \& Archives Canada (Bibliothèque et Archives Canada)

Introduction to the Music Collection housed within UBC's Music, Art and Architecture Library /

Présentation de la collection de musique abritée par la Bibliothèque de musique, d'art et

d'architecture de l'Université de la Colombie-Britannique

Kevin Madill | University of British Columbia (Université de la Colombie-Britannique)

11:00 am - 11:30 am

$11 \mathrm{~h}-11$ h 30

11:30 am - 12:30 pm

11 h $30-12$ h 30
Coffee Break / Pause-café

CAML/MUSCAN PLENARY SESSION/SÉANCE PLÉNIÈRE de I'ACBM et de MUSCAN | Chair/Présidence: Kevin Madill I Roy Barnett Recital Hall

Music Scholarship and Digital Technologies: Perspectives from Collaborative Corpus Building and 
$12: 30 \mathrm{pm}-2: 00 \mathrm{pm}$

$12 \mathrm{~h} 30-14 \mathrm{~h}$

2:00 pm - 5:00 pm $14 \mathrm{~h}-17 \mathrm{~h}$

5:00 pm - 7:00 pm $17 \mathrm{~h}-19 \mathrm{~h}$

Friday, 7 June 2019 Vendredi, 7 juin 2019

9:00 am - 11:00 am $9 \mathrm{~h}-11 \mathrm{~h}$

11:00 am - 11:30 am $11 \mathrm{~h}-11 \mathrm{~h} 30$

11:30 am - 12:30 pm 11 h $30-12$ h 30
Text Analysis / Érudition musicale et technologies numériques : constitution collaborative d’un corpus et réalisation d'une analyse de texte

Ève Poudrier \& Rémi Castonguay | University of British Columbia (Université de la Colombie-Britannique)

Lunch / Dîner

CAML/ACBM Collections Committee Meeting (Room 304) / Réunion du comité des collections de I'ACBM / de la CAML (Room 304)

SESSION/SÉANCE I| Chair/Présidence: Marc Stoeckle | Room/Pièce 116

Inetmoz - A Database for the Musical Heritage of Mozambique / Inetmoz : une banque de données consacrée à l'héritage musical du Mozambique

Carolina Sá, Maria Teresa Lacerda, Isaac Raimundo \& João Soeiro de Carvalho | Instituto de Etnomusicologia -

Centro de Estudos em Música e Dança

Graduate Student Contributions to Digital Research: A Tale of Two Projects / La contribution des étudiants des cycles supérieurs à la recherche numérique : le récit de deux projets Sean Luyk, Caitlin MacRae, Jamie Meyers-Riczu, Morteza Abedinifard, Kaitlyn Grant | University of Alberta (Université de l'Alberta)

Truth and Reconciliation in Canadian Music Libraries / Vérité et réconciliation dans les bibliothèques de musique canadiennes

Brian McMillan | University of Western Ontario (Université Western)

UBC President's reception/Réception du président de l'Université de la Colombie-Britannique | Robert H. Lee Alumni Centre

SESSION/SÉANCE III Chair/Présidence: Kevin Madill | Room/Piéce 116

The Organization and Representation of Musical Information in Portugal: a literature review / L'organisation et la représentation de l'information musicale au Portugal : une analyse documentaire

Carlos Guardado da Silva \& Antonio Baptista | University of Lisbon \& University of Coimbra (Université de Lisbonne et Université de Coimbra)

The Development and Impact of Electronic Resources on Library Music Collections and Services in Canada / Les ressources électroniques : leur incidence sur les collections de musique et les services offerts par les bibliothèques au Canada

Houman Behzadi, Kevin Madil \& Becky Smith I University of Toronto, University of British Columbia \& Memorial University of Newfoundland (Université de Toronto, Université de la Colombie-Britannique et Memorial Université de la Terre-Neuve)

Coffee Break / Pause-café

SESSION/SÉANCE IV Chair/Présidence: Kevin Madill | Room/Pièce 116

The Development of Unique Music Collections in Canada / La création de collections de musique uniques au Canada

Allison Richardson, Kevin Madill \& Marc Stoeckle | Kwantlen Polytechnic University, University of Calgary \& University of British Columbia (Université polytechnique de Kwantlen, Université de la Colombie-Britannique et Université de Calgary) 
$12: 30 \mathrm{pm}-2: 00 \mathrm{pm}$ 12 h $30-14$ h

2:00 pm $-4: 30 \mathrm{pm}$ $14 \mathrm{~h}-16 \mathrm{~h}$

$4: 30 p m-5: 30 p m$
CAML/ACBMAGM Lunch / Dîner et assemblée générale annuelle de l’ACMB / de la CAML

SESSION V Chair: Carolyn Doi | Room 116

Succession Planning in the Music Library: Putting Theory into Practice / La planification de la relève dans les bibliothèques de musique : mettre la théorie en pratique

Houman Behzadi \& Jan Guise | University of Toronto (Université de Toronto)

Future of CAML \& Future of National Music Edit-A-Thons / L'avenir de l'ACBM, y compris l'éditathon musique national

Monica S. Fazekas | University of Western Ontario (Université Western)

CAML/ACBM Board Meeting / Réunion du CA de l'ACBM/de la CAML 


\title{
PLENARY SESSION /SÉANCE PLÉNIÈRE
}

\author{
Music Scholarship and Digital Technologies: Perspectives from Collaborative Corpus Building and Text Analysis / \\ Érudition musicale et technologies numériques : constitution collaborative d'un corpus et réalisation d’une analyse de \\ texte \\ Ève Poudrier \& Rémi Castonguay | University of British Columbia (Université de la Colombie-Britannique)
}

Dr. Ève Poudrier, Assistant Professor of Music Theory, UBC School of Music, specialist in theories of rhythm and meter, twentiethcentury music, and music cognition, along with Rémi Castonguay, Librarian, speak to collaborations across professions in the field of music research with an emphasis on new technologies.

Ève Poudrier, Ph. D., chargée d'enseignement de la théorie de la musique à l'École de musique de l'Université de la Colombie-Britannique, se spécialise en théorie du rythme et de la mesure, en musique du vingtième siècle et en cognition musicale. Elle se joint à Rémi Castonguay, bibliothécaire, pour parler de collaborations possibles entre professionnels du domaine de la recherche musicale, en mettant l'accent sur les nouvelles technologies.

\section{SESSION 1 / SÉANCE 1}

Early Sound Recordings at Library and Archives Canada / Premiers enregistrements sonores à Bibliothèque et Archives Canada

Margaret Piper | Libraries \& Archives Canada (Bibliothèque et Archives Canada)

This paper will provide an overview of Library and Archives Canada's (LAC) collection of pre-1950 sound recordings. As the keeper of Canada's national cultural heritage, LAC is responsible for a diverse collection of materials. Within the institution, there is an array of specialists with different backgrounds such as art conservators, military history experts and musicians; I am fortunate enough to work as a Special Collections Librarian responsible for retrospective music and as an employee of Canada's national library, my role is unique in the music librarian community. I hope to offer some insight into how LAC's focus differs from that of Academic music libraries. Our retrospective music collection includes cylinders, 78-rpm discs, piano rolls, and other published materials with notable provenance, such as Oskar Morawetz's collection of autographed European scores and part of Sir Earnest Macmillan's library. In my presentation, I will provide an overview of the collection, highlighting some of the key publishers, formats, composers and performers. I will also discuss how we acquire this material and some of the challenges I encounter in my work.

Cette présentation fournit une vue d'ensemble de la collection d'enregistrements sonores pré-1950 de Bibliothèque et Archives Canada (BAC). Gardien de l'héritage culturel du Canada, BAC possède des collections variées et emploie des spécialistes de divers domaines : conservateurs, experts en histoire militaire et musiciens. J'ai le bonheur d'être bibliothécaire des collections spéciales et responsable de la musique rétro. En tant qu'employée de la bibliothèque nationale du Canada, je joue un rôle bien particulier au sein de la communauté des bibliothécaires de musique. Par ma présentation, je veux jeter une lumière sur la différence qui existe entre BAC et les bibliothèques de musique universitaires. Notre collection de musique rétrospective inclut des cylindres, des 78 tours, des partitions numériques en bandes ainsi que d'autres publications de noble provenance, comme la collection autographiée de partitions européennes d'Oskar Morawetz et une partie de la bibliothèque de sir Earnest Macmillan. Je fournis donc un aperçu de cette collection, en m'arrêtant à certains des éditeurs, des formats, des compositeurs et des artistes les plus importants. Je parle aussi de la méthode utilisée pour acquérir ce matériel ainsi que de certaines des difficultés inhérentes à mon travail.

Introduction to the Music Collection housed within UBC's Music, Art and Architecture Collection / Présentation de la collection de musique abritée par la Bibliothèque de musique, d'art et d'architecture de l'Université de la Colombie-Britannique

Kevin Madill | University of British Columbia (Université de la Colombie-Britannique)

A one-hour tour of the music collection and accompanying services embedded in UBC's Music, Art + Architecture Library. To be offered during a lunch or afternoon break. Tour will include an informative but critical walk-through of the branch with emphasis on music related services and extensive score collection, interesting items on display, hidden collections, a pit stop to the Automated Storage and Retrieval System under the branch, and music materials in UBC Library's Rare Books and Special Collections 
(e.g., the largest collection of early music facsimiles in the Pacific North West, the Canadian Women Composers Archive Collection, the Brahms First Edition Collection, the Colin Slim Stravinsky Collection, and more.

Une visite guidée d'une heure de la collection de musique ainsi que des services offerts par la Bibliothèque de musique, d'art et d'architecture de l'Université de la Colombie-Britannique. Cette visite, qui inclut une tournée informative et indispensable de l'établissement, se focalise sur les services relatifs à la musique, l'imposante collection de partitions, les articles exposés et les collections cachées. Elle comprend un bref arrêt au système d'entreposage automatisé de l'établissement ainsi qu'une visite du matériel musical intégré à la section des livres rares et des collections spéciales de l'université (p. ex. : la plus grande collection de fac-similés de musique ancienne sur la côte nord-ouest du Pacifique, la collection d'archives de compositrices canadiennes, la collection de l'édition originale de Brahms, la collection Colin Slim Stravinsky, et plus encore).

\title{
SESSION 2 / SÉANCE 2
}

\author{
Inetmoz - A Database for the Musical Heritage of Mozambique / Inetmoz : une banque de données consacrée à \\ I’héritage musical du Mozambique \\ Carolina Sá, Maria Teresa Lacerda, Isaac Raimundo \& João Soeiro de Carvalho| Instituto de Etnomusicologia - Centro de Estudos em Música e \\ Dança
}

The project Timbila, Makwayela and Marrabenta: one century of musical representation of Mozambique aims to preserve the cultural heritage of musical experience in Mozambique in the twentieth century, as well as its connections with Portugal. The evolution of the Mozambican musical experience throughout the twentieth century was recorded by the phonographic industry as well as radio stations. However, the advent of the Digital Age has rendered many of the technologies used obsolete, making contemporary access to these sources difficult. As such, InetMoz, the database of the project that we present here, is centered on the organization, preservation and study of phonograms, culminates in a creation of a database that is both academic and intuitive. This database It serves to return the music to the community, since it not only compiling and relating the data, but and also providing access to recordings in $\mathrm{mp} 3$ format. The preservation and digitization of magnetic tapes, discs and bibliography for the database follows international norms such as those outlined in I.A.S.A. TC-04. The transcription into the digital domain is complex due to the diversity of magnetic carriers of video and sound in the process of the digital domain. The scanned contents, in a ddition to being available in the InetMoz database (https://goo.gl/YAoL1x), are available in uncompressed formats - wave and tiff - for long term archive, in various locations.

Le projet «Timbila, Makwayela et Marrabenta : un siècle de représentation musicale au Mozambique » a pour but de préserver I'héritage culturel et musical du Mozambique au vingtième siècle, et de documenter les liens de ce pays avec le Portugal. Au cours des années 1900, l'industrie phonographique et les stations de radio ont enregistré l'évolution de l'expérience musicale mozambicaine. Avec l'avènement de l'ère numérique, ces technologies sont toutefois devenues obsolètes, et l'accès aux enregistrements est devenu difficile. Du fait qu'InetMoz se centre sur l'organisation, la préservation et l'étude des phonogrammes, elle est une base de données didactique, mais aussi intuitive. La compilation et le traitement de ces données nous permettent de rendre sa musique à la collectivité et de lui en offrir l'accès au moyen d'enregistrements au format mp3. Nous avons respecté les normes internationales comme celles établies dans le IASA-TCO4 lorsque nous avons préservé et numérisé les bandes magnétiques, les disques et la bibliographie de la banque de données. Étant donné la diversité de lecteurs audio et vidéo, la conversion de leurs fichiers au numérique constitue un processus complexe. En plus d'être disponibles sur InetMoz (https://goo.gl/YAoL1X), les données numérisées sont offertes, en divers endroits, en formats non compactés - WAVE et TIFF - pour en faciliter l'archivage.

\section{Graduate Student Contributions to Digital Research: A Tale of Two Projects / La contribution des étudiants des cycles supérieurs à la recherche numérique : le récit de deux projets \\ Sean Luyk, Caitlin MacRae, Jamie Meyers-Riczu, Morteza Abedinifard, Kaitlyn Grant | University of Alberta (Université de l'Alberta)}

Graduate research assistants play an essential role in the success of large-scale, collaborative research projects in music. Projects that include a digital research component pose additional challenges to both researchers and graduate students alike, including those related to selecting and curating digital content, creating culturally appropriate metadata, and designing systems that are appealing and usable for their intended audiences. This roundtable brings together five graduate research assistants and one librarian from two such projects: Resounding Culture: Recontextualizing Resources for Histories of Music in Canada, and Sounds of Home: Exploring Local Music Collections and Collecting in Canada. Both of these projects involved close collaboration between music researchers, librarians, technologists, and graduate students from music, digital humanities, and library and information science programs. Following a roundtable format, this panel will begin with each graduate student discussing their role on these 
projects, how they contributed to their success, lessons learned, challenges they faced, and how cross-disciplinary collaboration introduced new perspectives to their research. The roundtable will be moderated by a librarian/researcher on these projects, who will close the panel with recommendations of best practices for managing large-scale digital research projects that involve graduate research assistants who were geographically and disciplinarily dispersed.

Les adjoints à la recherche des cycles supérieurs jouent un rôle essentiel dans la réussite de projets collaboratifs à grande échelle dans le domaine de la musique. Or, l'aspect numérique de la recherche ajoute aux difficultés des chercheurs et des étudiants. Cet aspect comprend : la sélection et l'organisation du contenu numérique, la création de métadonnées au contenu culturel approprié et la conception de systèmes attirants et faciles à utiliser pour les auditoires cibles. Cette table ronde réunit cinq adjoints à la recherche des cycles supérieurs ainsi qu'un bibliothécaire ayant travaillé à l'un de deux projets: "Culture retentissante: contextualiser l'histoire de la musique au Canada » (en anglais seulement) et " Sons familiers : étudier les collections et la collecte de musique locale au Canada ». Ces deux projets ont exigé que chercheurs, bibliothécaires et technologues du domaine de la musique coopèrent étroitement avec des étudiants des cycles supérieurs en musique, en sciences humaines numériques, en bibliothéconomie et en science de l'information. Chaque étudiant parle du rôle qu'il a joué dans le cadre de ce projet, de sa contribution à sa réussite, des leçons apprises et des difficultés affrontées, ainsi que des nouveaux horizons que lui a ouverts une collaboration interdisciplinaire. Le bibliothécaire associé à l'un de ces projets agira comme modérateur. II clôturera cette table ronde en présentant ses recommandations quant aux meilleures pratiques à adopter pour gérer un projet de recherche numérique de grande envergure qui rassemble des adjoints à la recherche provenant de disciplines et d'endroits divers.

\section{Truth and Reconciliation in Canadian Music Libraries / Vérité et réconciliation dans les bibliothèques de musique canadiennes \\ Brian McMillan | University of Western Ontario (Université Western)}

Since the 2015 release of the final report of Canada's Truth and Reconciliation Commission, libraries and universities across the country have worked to address its 94 calls to action. Beyond purchasing more indigenous music in support of curriculum, what steps can music librarians take individually, in collaboration with other campus units, and as a part of national organizations such as CAML? This presentation, featuring a music librarian in discussion with a UBC aboriginal services librarian, will explore the meaning of reconciliation, indigenization of university curricula, and the implications of existing guidelines for future action.

Depuis que la Commission de vérité et réconciliation du Canada a déposé son rapport en 2015, les bibliothèques et les universités à l'échelle du pays tentent de mettre en pratique ses 94 recommandations. En plus d'acquérir de la musique autochtone pour les programmes d'enseignement, que peuvent faire les bibliothécaires de musique sur les plans individuel et collectif, soit en collaborant avec d'autres campus ainsi qu'avec des organisations nationales comme l'ACBM? En s'inspirant de ses échanges avec une bibliothécaire de l'Université de la Colombie-Britannique assignée aux services aux Autochtones, le présentateur réfléchit sur la signification de la réconciliation, l'adaptation du curriculum universitaire à la réalité autochtone et la suite à donner aux lignes directrices.

\section{SESSION 3 / SÉANCE 3}

\section{The Organization and Representation of Musical Information in Portugal: a literature review / L'organisation et la représentation de l'information musicale au Portugal : une analyse documentaire \\ Carlos Guardado da Silva \& Antonio Baptista | University of Lisbon \& University of Coimbra (Université de Lisbonne et Université de Coimbra)}

This article reviews the literature in order to organize the knowledge about the state of the question about Organization and the Representation of Musical Information (ORMI) in Portugal, considering the different typologies of collections. Many authors describe the ORMI national scene as very lacunar. In spite of this context, this work intends to make a survey of the sources of bibliographical information, namely, monographs and articles published in the last ten years, in order to carry out a critical review of the scientific and technical works of ORMI developed in several institutions Portuguese. It also intends to perceive the state of ORMI, as well as the national knowledge about the musical information accumulated in different memorizing institutions. Thus, our starting question is as follows: What is the state of knowledge about the Organization and Representation of Musical Information in Portugal? To answer this question, our research, of a qualitative and quantitative nature, is based mainly on the documentary research method, based on research in several repositories as a source of information, namely the RCAAP portal for the Open Access Scientific Repositories of Portugal, and several databases, with resources to the terms \&quot;Catalog* AND music*\&quot; or just \&quot;music*\&quot;. The research focused on music cataloguing and studies on music in the area of Information Science. As a result, we aim to achieve a state of knowledge about ORMI in Portugal. 
Cette présentation analyse la documentation disponible portant sur l'organisation et la représentation de l'information musicale (ORMI) au Portugal en dégageant les diverses typologies des collections. De nombreux auteurs sont d'avis que, sur la scène nationale, ORMI est très lacunaire. Malgré cette situation, nous voulons examiner les sources d'information bibliographique, nommément les monographies et les articles publiés au cours des dix dernières années, afin d'en tirer une révision critique des $œ u v r e s$ scientifiques et techniques d'ORMI entreprises par certains établissements portugais. Nous souhaitons également diagnostiquer l'état d'ORMl et évaluer à quel point le public portugais est conscient de la quantité de musique stockée à différents endroits. Notre question de départ est donc la suivante : Dans quel état se trouve ORMI au Portugal? Pour y répondre, notre recherche qualitative et quantitative se base principalement sur une analyse documentaire de plusieurs services d'archives, dont le portail RCAAP des archives scientifiques en libre accès du Portugal ainsi que de plusieurs banques de données correspondant aux termes de recherche \&quot;Catalog* ET music*\&quot, ou tout simplement : \&quot;music*\&quot. Notre recherche traite plus particulièrement du catalogage de la musique et des études qu'a entreprises la science de l'information sur la musique. Ainsi, nous avons pour but d'en savoir davantage sur ORMI au Portugal.

\section{The Development and Impact of Electronic Resources on Library Music Collections and Services in Canada / Les ressources électroniques : leur incidence sur les collections de musique et les services offerts par les bibliothèques au Canada \\ Houman Behzadi, Kevin Madil \& Becky Smith | University of Toronto, University of British Columbia \& Memorial University of Newfoundland (Université de Toronto, Université de la Colombie-Britannique et Memorial Université de la Terre-Neuve)}

The practice of acquisitioning music resources in electronic rather than physical formats has been an option for music librarians sufficiently long enough for there now to be a history upon which to build a discussion regarding the practice's impact on existing music collections, music collecting practices, music libraries, and the profession of music librarianship itself. The purpose of such a discussion is to share past experiences in the hope of identifying issues going forward specific to the profession of music librarianship, as well as building a community of support across Canadian institutions for those privileging the practice. Within the framework of a round table, three music librarians present their experiences (10 minutes each) moving their collections towards 'e.' An open discussion follows to encourage attendees to share added thoughts and experiences. Presentation topics covered include: ordering issues, collection control issues, patron-based responses to the move to electronic resources, impact on external users, impact on subject specific collection budgets (e.g., long-term costs, negotiating costs, impact of CKRN, deaccessioning, budget cuts, licensing agreements, etc.), impact on monographs versus scores versus journals versus audio/visual databases, administrative response/support to format shift (e.g., transformations to music collection physical space as physical collections diminish), and more.

Les bibliothécaires de musique peuvent depuis assez longtemps déjà acquérir des ressources musicales en format électronique plutôt que physique pour que nous puissions maintenant nous entretenir des retombées de ce procédé sur les collections de musique, les pratiques en matière de collecte, les bibliothèques de musique et la bibliothéconomie de la musique. Durant cette présentation, nous parlons de nos expériences afin de cerner les problèmes potentiels, particuliers à la bibliothéconomie de la musique, et de bâtir un réseau de soutien dans tous les établissements canadiens où l'on favorise cette pratique. Dans le con texte de cette table ronde, trois bibliothécaires de musique racontent (10 minutes chacun) le parcours qu'ils ont suivi en faisant passer leurs collections au format électronique. Leur présentation sera suivie d'une discussion au cours de laquelle on encouragera les personnes présentes à faire part de leurs opinions et de leurs expériences. Au programme : passation de commandes, contrôle des collections, réaction des utilisateurs aux ressources électroniques, incidence sur les utilisateurs externes, répercussions sur les budgets assignés précisément à certaines collections ( $p$. ex. : coûts à long terme, négociation des coûts, incidence du RCDR, retrait d'inventaire, compressions budgétaires, contrats de licence, etc.), conséquences sur les monographies, les partitions et les journaux par rapport aux bases de données audiovisuelles, réaction des administrateurs et leur soutien quant au changement de format (transformation des endroits où sont abritées les collections de musique dans la mesure où les collections tangibles diminuent) et plus encore.

\section{SESSION 4 / SÉANCE 4}

The Development of Unique Music Collections in Canada / La création de collections de musique uniques au Canada Allison Richardson, Kevin Madill \& Marc Stoeckle | Kwantlen Polytechnic University, University of Calgary \& University of British Columbia (Université polytechnique de Kwantlen, Université de la Colombie-Britannique et Université de Calgary)

Music libraries offer singular opportunities for the development of unique collections. Three librarians present (twelve minutes each) on their experiences initiating, developing, and sustaining a music collection unique to their institution in Canada. 
Fundamental to the discussion are the following topics: the role of unique collections in supporting the identity and role of the institution and library to which they are attached; the importance of subject-specific librarianship and education to develop unique collections; issues related to administrative support for the development of unique collections; funding issues related to unique collections; expected and unexpected accessioning, access, and preservation issues specific to unique collections; the impact of developing a unique collection on sister collections (e.g., Rare Books and Special Collections); and more. The purpose of the session is to serve as a primer for others interested in developing unique music collections in their own libraries.

Le contexte d'une bibliothèque de musique offre de belles occasions de développer des collections uniques. Trois bibliothécaires font part de leurs expériences (12 minutes chacun) relatives à la création, au développement et à la préservation d'une collection de musique particulière à leur établissement canadien. Cette discussion se base sur les points suivants : le rôle que jouent les collections dans l'affermissement de l'identité et de la vocation de l'établissement et de la bibliothèque auxquelles elles se rattachent; l'importance d'une bibliothéconomie et d'une formation spécialisées pour créer des collections uniques; le soutien administratif nécessaire à la création de collections uniques; le financement requis pour bâtir de telles collections; les questions d'archivage (prévisibles ou non), d'accès et de préservation particulières aux collections uniques; l'incidence de la création d'une collection unique provenant d'une collection qui lui est apparentée (p. ex. : livres rares et collections spéciales); et plus encore. Cette séance a pour but d'enseigner les rudiments de la création de collections de musique uniques à des gens qui s'intéressent à ce sujet.

\title{
SESSION 5 / SÉANCE 5
}

\author{
Succession Planning in the Music Library: Putting Theory into Practice / La planification de la relève dans les \\ bibliothèques de musique : mettre la théorie en pratique \\ Houman Behzadi \& Jan Guise | University of Toronto (Université de Toronto)
}

\begin{abstract}
Although we often think of succession planning in the context of retirements, there are other reasons colleagues leave positions which can happen more suddenly than a retirement. We can usually predict a retirement, and we can have the retirement conversation well in advance of a colleague choosing that path. When a younger colleague departs for another job, or falls ill for an extended period of time, we don't always have much notice so planning can be much more difficult. Librarians at the University of Toronto typically spend their entire careers there. Colleagues rarely depart the institution for reasons other than retirement. Occasionally, however, librarians change jobs within the organization. Succession planning is crucial in such cases to avoid the colleague "wearing two hats" until a replacement is found. Such an expectation is not fair to the colleague (who is trying to learn the new job) nor is it fair to the colleague's co-workers (Can we still call Bill to solve this problem?). This presentation describes a real-life situation from the University of Toronto Music Library. Houman Behzadi accepted a new position elsewhere in the $U$ of $T$ Libraries system, with a start date of January 1 st 2019. Given less than a month of transition time, Jan and Houman communicated with stakeholders and developed a job shadowing process and transition timeline. We also found opportunities for initiating meaningful change in the collections services workflows.
\end{abstract}

Nous pensons souvent à la planification de la relève dans le contexte de la retraite, mais il arrive que des collègues quittent soudainement leur emploi, pour une raison autre que la retraite. Il est en général facile de prédire une retraite, et nous pouvons en discuter longtemps avant que le collègue parte. Toutefois, lorsqu'un jeune collègue accepte un autre emploi ou qu'il doit prendre un congé de maladie, nous n'avons pas le loisir de planifier, ce qui complique la situation. La plupart des bibliothécaires de l'Université de Toronto ne quittent en général leur emploi que pour prendre leur retraite. Cependant, certains bibliothécaires sont parfois mutés au sein de l'établissement. La planification de la relève s'avère cruciale dans ce cas pour éviter à celui qui reste d'exercer plus d'une fonction jusqu'à ce que l'on engage un remplaçant. Cette situation n'est juste ni pour le collègue qui reste (qui tente d’apprendre de nouvelles tâches) ni pour ses compagnons de travail («Pouvons-nous toujours téléphoner à Jean pour qu'il nous aide? »). Cette présentation fait état d'un cas réel s'étant produit à la bibliothèque de musique de l'Université de Toronto. Ayant accepté un nouveau poste à l'intérieur du réseau des bibliothèques de l'université, Houman Behzadi devait entrer en fonction le $1^{\text {er }}$ janvier 2019, ce qui lui accordait une période de transition de moins d'un mois. Janneka et Houman ont donc communiqué avec des parties prenantes et ont créé un horaire relatif au processus de jumelage et de transition. Ils en ont également profité pour améliorer le flux des travaux à la bibliothèque.

Future of CAML \& Future of National Music Edit-A-Thons / L'avenir de l'ACBM, y compris l'éditathon musique national Monica S. Fazekas | University of Western Ontario (Université Western)

At this session we will discuss the following:

1. Who do we want CAML members to be (academic librarians, public librarians, special librarians) and how do we bring in colleagues who have music responsibilities as only part of their job (decreasing numbers of subject specialists). What can we offer them? Why should they join CAML?

2. Should CAML be part of an organization other than FedCan, or in addition to FedCan, (e.g. CFLA)? 
3. Should we do more online? Webinars, meetings etc.?

4. How important is community engagement to CAML?

5. Can we keep the momentum going for CAML taking the lead in a national music-focused edit-a-thon and/or other music-focused Wikimedia projects?

Discussion points:

a) What are other people doing at their institutions (music or otherwise)

b) What partnerships could we make with other music (GLAM) organizations for a national campaign (e.g. Canadian Music Centre, JUNOs, Canadian Music Hall of Fame etc.)? How can we bring them onboard?

c) When would be the best time of year to host a national campaign (coincide with JUNOS, Open Access Week - something else)?

d) Could this be an international campaign with national branches?

Lors de cette séance, nous discuterons des sujets suivants:

1. Quelles fonctions voulons-nous que nos membres exercent (bibliothécaires d'université, municipaux ou spécialisés)? Comment attirer des collègues qui ne travaillent qu'à temps partiel dans le domaine de la musique (en raison du nombre décroissant de spécialistes)? Quels avantages pouvons-nous leur offrir? Pour quelles raisons adhéreraient-ils à l'ACBM?

2. L'ACBM devrait-elle se joindre à une organisation autre que la Fédération des sciences humaines (FSH) ou à certaines organisations en plus de la FSH (p. ex. : la Fédération canadienne des associations de bibliothèques (FCAB)?

3. Devrait-elle avoir une présence accrue en ligne (p. ex. : webinaires, réunions, etc.)?

4. Dans quelle mesure l'engagement communautaire est-il important pour l'ACBM?

5. L'ACBM peut-elle continuer sur sa lancée et s'affirmer comme leader d'un marathon d'édition national sur la musique ou de tout autre projet axé sur la musique de Wikimédia?

Points à discuter :

a) Comment s'y prennent les autres dans leur établissement respectif (en musique ou dans un domaine différent)?

b) Dans le but de mener une campagne nationale, quels partenariats l'ACBM pourrait-elle créer avec des organisations de musique (p. ex. : Centre de musique canadienne, prix Juno, Panthéon de la musique canadienne, etc.)? Comment s'assurer leur concours?

c) Quel serait le meilleur temps de l'année pour tenir une compagne nationale (la faire coïncider avec les prix Juno, l'Open Access Week (semaine du libre accès) ou un autre événement?

d) Serait-ce possible d'en faire une campagne internationale ayant des sections nationales? 


\section{Cataloguing Committee \\ Report of activities since CAML's 2018 AGM in Regina, Sask.}

(As submitted for the 2019 CAML AGM, June 7, 2019)

As Chair of the Committee, I attended a teleconference meeting of the Canadian Cataloguing Committee (CCC) on September 19, 2018. Due to the RDA Toolkit Restructure and Redesign Project (3R) project, there was no RDA revision proposal to review this year.

I am also a member of the RDA Steering Committee (RSC) Music Working Group. Because new revision proposals are not accepted during the $3 R$ Project, the Working Group has no new activity to report.

It should be noted that the beta version of the redesigned RDA Toolkit was released on June 13, 2018 (see the announcement here). Since then, five updates brought many changes and improvements to the content of the instructions and the site functionality. Many of the improvements came through feedback provided by users. The April 2019 update marked an important milestone in the $3 R$ Project since it included the stabilized English language version of the RDA standard (see the announcement here). The achievement of this goal opens a new phase in the $3 R$ Project where the focus will be on the development of translations and policy statements. It is important to note that the $3 R$ Project has not been completed yet and that the original RDA Toolkit remains the official version of RDA until the project is declared complete.

The current roster of the Committee is as follows:

Megan Chellew, McGill University

Carolyn Doi, University of Saskatchewan (ex-officio)

Daniel Paradis, Bibliothèque et Archives nationales du Québec (Chair)

Andrew Senior, McGill University

It is with regret that I announce that this is my last report as Chair of the Cataloguing Committee. I decided to step down since my current responsibilities at BAnQ and within the RDA Steering Committee no longer allow me to continue. I believe it is also time to let someone else have the chance to lead this Committee as we continue to make cataloguing standards evolve to take advantage of new technologies. I'm very thankful for the opportunity to serve as the Chair over the past many years, which laid the groundwork for the work I am now doing as a member of the RDA Steering Committee.

Respectfully submitted by

Daniel Paradis, Chair

daniel.paradis@banq.qc.ca 


\title{
Minutes of the 2018 CAML/ACBM Annual General Meeting
}

\author{
Canadian Association of Music Libraries, Archives and Documentation Centres (CAML) \\ L'Association canadienne des bibliothèques, archives et centres de documentation \\ musicaux (ACBM)
}

Friday, June 1, 2018, 12:30 PM

Rm 311 Education Building, University of Regina

\section{(As approved at the 2019 CAML AGM, June 7, 2019)}

\section{Attendees}

Houman Behzadi, Scott Cowan, Carolyn Doi, Monica Fazekas, Jan Guise, Katelyn Hicks, Kyla Jemison, Cathy Martin, James Mason, Brian McMillan, Tim Neufeldt, Maureen Nevins, Katherine Penner, Lelland Reed, Laura Snyder, Rob van der Bliek

Call to order: 12:34 PM

1) Approval of Agenda - Brian McMillan, Second - Houman Behzadi (Carried)

2) Approval of Minutes from 2017 AGM

a. Change names on audit committee - 2017 members were Tim Neufeldt and Maureen Nevins

b. Change names in CAML Review Report - Change Sean Luyk to Desmond Maley as Review Editor

c. Motion for Approval of 2017 minutes (with changes) - Maureen Nevins, Second Kyla Jemison (Carried)

3) Local Arrangements

a. Many different formats/events happening at this CAML conference: smudging ceremony, more workshop format sessions, dinners at Cathedral Social Hall \& La Bodega, and all are encouraged to take part in the many interesting sessions going on in larger Congress

i. Local Arrangements: Gillian van der Ven \& Tim Neufeldt

ii. Thank you to the Local Arrangements committee for their work organizing this conference

iii. Program Committee: Tim Neufeldt, Brian McMillan, Becky Smith

iv. Many thanks to the committee for their work on this program

b. Looking to next year - CAML to meet with MusCan at Congress 2019 (UBC) 
4) Reports

a. President's report (Carolyn Doi)

i. Board met 4 times this year

ii. Completed board procedures manual

1. Action: Tim Neufeldt to add conference procedures

iii. Quebec Chapter to meet in November with NY Chapter of MLA

iv. A number of board changes:

1. New board member 2017 - Katherine Penner (Secretary)

2. Vacating positions from current board -

a. Kyla Jemison stepping down as Membership Secretary

b. Rob van der Bliek stepping down as Treasurer

c. Brian McMillan's term as Past President ends

b. Treasurer's report (Rob van der Bliek)

i. 2017 budget

1. Surplus from 2017 CAML Conference

2. Banking fees have increased as result of a move from a community account to business account.

ii. 2018 budget

1. Figures to date reviewed, but we don't have conference costs yet

iii. 2019 budget

1. Presented

iv. Thank you to Rob for his 10 years in this position!

c. Audit Committee report (Maureen Nevins)

i. Written report submitted

ii. Committee (Maureen Nevins \& Lelland Reed) met May 31 to review records

1. Examined all documentation from Jan 1 - December 31, 2017

2. Committee advises all cheques deposited right away

3. Committee advises more consistent transfers of PayPal Account funds

4. Committee advises printing bank statements

5. Committee has one vacancy pending (Maureen Nevins), any interested parties should contact Lelland Reed

d. Membership Secretary's report (Kyla Jemison)

i. 54 Individual, 5 CAML/IAML Retired

ii. 9 new personal members

iii. New: CAML offered donation option at renewal

iv. Question re: CAML/MusCan Reciprocal Membership - we've only had 1 membership, does the board feel the need to continue this option?

1. Action: Board to discuss internally

v. Thank you to Kyla for her 8 years in this position!

e. Communication Officer's report (James Mason)

i. Had some issues at various institutions getting to CAML website, and for the most part, these have been resolved

ii. Still having issues with bots mining our site and sending false emails around the board 
1. Action: change email addresses to \{joe [at] institution.ca\} to help with bot mining

iii. Will be making visual changes to the site, implement a better infrastructure for the site, will ask for CAML library photos for the site

f. CAML Review report (Cathy)

i. Editorial team also includes Brian Thompson (Books/Recordings Review Editor) and Deborah Wills and Megan Chellew (Associate Editors). Rob van der Bliek has been adding DOls.

ii. Published 2 issues since last AGM, including one dual issue

iii. Potential materials to be reviewed are now being listed on the journal site

iv. Cathy will be stepping down as Editor

1. Action: Board to put out a call for a new CAML Review editor

v. Thank you to Cathy for many years of her work on the publication!

g. Nomination Officer's report (Jan Guise)

i. One nomination for each Treasurer and Membership Secretary

1. President's acclamations:

a. Treasurer - Tim Neufeldt

b. Membership Secretary - Becky Smith

c. President-Houman Behzadi

2. Action: Board to put out call for Member-at-large position that Houman will be vacating

ii. If there is ever need for an electronic vote, we have the capacity

h. Cataloguing Committee report (Daniel)

i. Note (Carolyn): Membership is low, so call will go out on the listserv shortly

i. R-Committee reports

i. No chairs, no committees

j. Collections Committee report (Houman)

i. 9 Members, with pan-Canadian representation

ii. Houman Behzadi, Audrey Laplante and Joseph Trivers will rotate off committee after 2 years of service, so a call will go out for new members

iii. Met three times this year

iv. Board request for pre-Conference workshop noted, and will keep this as a consideration for next year.

v. Houman will rotate off MLA Collections Committee this year

k. Quebec Chapter report (Rachel via Houman)

i. Annual Meeting - Nov 32017

ii. 36 members present at conference

iii. Finances healthy, will support November 8-9 conference in Montreal

I. Awards Committee report (Houman)

i. Houman, Tim (Program Chair), Becky Smith (Member in good standing)

- Received no applications for research award

- Received and accepted first-time attendee, who declined

- Received one first-time presenter application, which was rejected by the Committee

m. Motion to accept reports: Tim, Second - Jan (Carried) 


\section{5) Committees}

a. Will be putting out call for CAML Review

i. Action: Call for CAML Review Editor to go out

b. R committees do not have representation right now

i. Action: Board to reach out to RILM to see what is needed

c. Will need Audit Committee 2nd member who will (ideally) be at both 2019 and 2020 meetings

i. Action: Call for volunteers for Audit Committee to be sent

d. Will need Program Committee chair

i. Action: Call for volunteers for Program Committee CAML 2019 to be sent

e. Will need Collections Committee chair

i. Action: Carolyn to appoint Collections Committee chair

f. Will need Member-at-large

i. Action: Call for nominations for Member-at-large to be sent

6) CAML Conference 2019

a. MusCan will be meeting with Congress next year, tentatively Jun 5-7

b. President has also reached out to CAPAL not to overlap

c. IASPM is also meeting with Congress this year, may be a possibility for coordinating meetings

d. Kevin Madill will be local arrangements

i. Would the membership be interested in a pre-conference session for the 2019 Congress in Vancouver?

ii. Discussion: pre-conference is a good way to do outreach, workshops seemed to work this year, possibility to work more closely with other cultural institutions that might be able to lend more to the program (conservatories, galleries, public library)

7) Other business (Carolyn)

a. Gendered language in CAML Constitution 5.7.6.2:

Proposed change: remove "his" and change to un-gendered language

i. Motion to make proposed changes - Carolyn, Seconded by Jan (Carried)

8) Motion to adjourn: Monica Fazekas - second James (Carried)

Meeting Adjourned: 1:44 PM

Respectfully Submitted, Katherine Penner (Secretary) 


\section{Stu Davis: Canada's Cowboy Troubadour}

\section{by Brock Silversides}

Stu Davis was an immense presence on Western Canada's country music scene from the late 1930s to the late 1960s. His is a name no longer well-known, even though he was continually on the radio and television waves regionally and nationally for more than a quarter century. In addition, he released twenty-three singles, twenty albums, and published four folios of songs: a multi-layered creative output unmatched by most of his contemporaries.

Born David Stewart, he was the youngest son of Alex Stewart and Magdelena Fawns. They had emigrated from Scotland to Saskatchewan in 1909, homesteading on Twp. 13, Range 15, west of the 2nd Meridian. ${ }^{1}$ This was in the middle of the great Regina Plain, near the town of Francis. The Stewarts

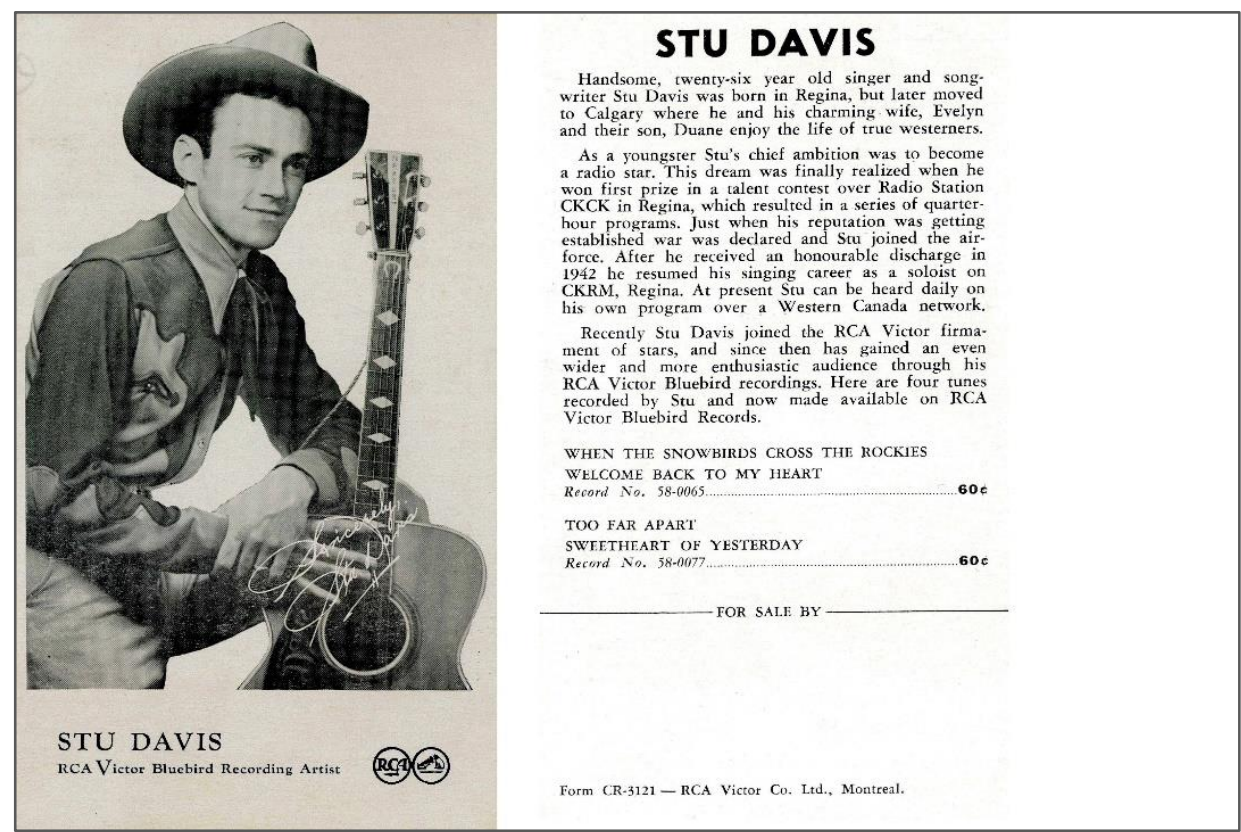

Sales card for Stu Davis (Montreal: RCA Victor Co. Ltd.) 1948

Library \& Archives Canada

Brock Silversides (brock.silversides@utoronto.ca) is Director of the University of Toronto Media Commons.

1. Census of Manitoba, Saskatchewan and Alberta 1916, Saskatchewan, District 31 Weyburn, Subdistrict 22, Township 13 Range 15, W2M, Schedule No. 1, 3.

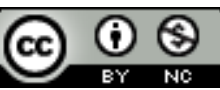

This work is licensed under a Creative Commons Attribution-NonCommercial 4.0 International License. 
managed to keep the farm going for more than a decade, but only marginally. In 1920 they moved into Regina where Alex found employment as a gardener, then as a teamster for the City of Regina Parks Board. The family moved frequently: city directories show them at 1400 Rae Street (1921), 1367 Lorne North (1923), 929 Edgar Street (1924-1929), 1202 Elliott Street (1933-1936), 1265 Scarth Street for the remainder of the 1930 s, and 1178 Cameron Street through the war years. ${ }^{2}$

Through these moves the family kept a hand in farming, with a small farm 12 kilometres northwest of the city near the hamlet of Boggy Creek, a stone's throw from the scenic Qu'Appelle Valley. That is where Stewart was born in 1921. The family lived on the farm all summer, and in Regina during the school year. Raised during the Depression-which was particularly bleak in Saskatchewan due to an extended drought-Stewart's favourite childhood activity was listening to the radio, no doubt inspired by the 257 -foot transmitter tower built by Regina radio station CKCK and located right at Boggy Creek.

Stewart became fascinated with country \& western music in particular, and as he later explained:

From the time I was knee-high to a grasshopper, I had a hankering for western music. It wasn't until I was twelve years old, though, that I started collecting cowboy songs and ballads. From that time on I collected just about every western ditty that ever was sung. ${ }^{3}$

Upon graduation from high school, he secured a job as a lens grinder with Consol Optical Co. from 1938 to $1940 .{ }^{4} \mathrm{He}$ also started performing as one half of the Harmony Boys (with his older brother Fred) in his teens.

CKCK was the first commercial radio station in Saskatchewan, established in 1922. Like other broadcasters, it had evolved quickly over its first fifteen years of operation. Programming had started with only a couple of hours of content per day. That included news (usually a reading of stories from The Leader), weather, and farm reports, particularly the grain prices. Then they added the occasional church service, talks and lectures, and hockey games. Musical entertainment was slowly added into the mix, with some local performers, but in the mid-1920s, more air time was given over to American transcription discs and commercially available recordings.

In 1925 the Federal Government's Radio Branch brought in a regulation that forbade all broadcasters from airing recordings between 7:30 and midnight. It was based on the assumption that this music just duplicated what people were playing on their gramophones at home, and also that these recordings

2. Regina City Directory (Regina: Henderson Directories), 1921-22, 441; 1922, 430; 1924, 412; 1929, 586; 1933, 502; 1937, 518; 1938, 522; 1939, 525; 1940, 541; 1943, 516; 1944, 462; 1946, 495.

3. Stu Davis, Stu Davis' Song Corral, Folio No. 1 (Toronto: Gordon V. Thompson, 1948), inside front cover.

4. Regina City Directory, 1938, 523; 1939, 526; 1940, 541. 
were overwhelmingly American and had no connection to community life. ${ }^{5}$ For evening programming, the stations started hiring (or getting sponsors to pay for) performances by local orchestras and choirs.

The Depression hit the radio stations hard-as it did all businesses-and radio in that period was not a particularly profitable venture to begin with. Prairie broadcasters found they could not afford to pay large ensembles, nor find sponsors, nor acquire and maintain a good record library. As one Canadian radio historian writes, "Many stations were so poor that they could not afford to hire good artists, they filled up the evening hours instead with second-rate performers and "amateur" hours." ${ }^{6}$ On the other hand it was just the encouragement needed to get amateurs out of their living rooms and try expressing themselves to a larger public.

Into this less-than-promising scenario, several instances of real talent stepped up to the CKCK microphone. The first was Eric Edwards, a penniless wanderer with a penchant for yodeling and trick riding. Upon arriving in Regina one day in 1937, he decided to take a break from riding the rails. He heard of an amateur talent show with Wilford "Bill" Schultz, disc jockey, which guaranteed that any performer would get a free breakfast at the Army and Navy store. That was all the incentive he needed, and Edwards yodeled his way through two songs. Schultz liked what he heard, and Edwardsrechristened "Alberta Slim" - became a regular performer on CKCK for the next three years. He went on to host programs at CFQC in Saskatoon and CJRM in Moose Jaw, and had a musical recording career as well.

Another glimpse of obvious talent was found in David Stewart. In 1938 Schultz was looking for yet more local talent to fill out the broadcast schedule. As Stewart modestly remembered:

I decided to try for an audition after I heard some of the western singers of the day and figured I couldn't be much worse. The audition was successful and led to a daily 15minute series on CKCK. ${ }^{7}$

He entered the contest with an assumed name to avoid embarrassing his family if he was rejected. With the win however, he decided to keep his stage name, Stu Davis. His confidence increased, and Davis became a host/performer on Studio Party Barn Dance. Since 1936, CKCK had been run by the management firm of Taylor, Pearson and Carson Ltd. They also managed sister stations CFAC (Calgary), CJCA (Edmonton), and CJOC (Lethbridge), and there were frequent exchanges of both executives and talent among the four. Their choice for general manager of CKCK in 1939 and 1940 was Gerry Gaetz, a name that would recur in Davis's career. ${ }^{8}$

5. Mary Vipond, Listening In: The First Decade of Canadian Broadcasting, 1922-1932 (Montreal, QC: McGillQueen's University Press, 1992), 127.

6. Vipond, 127.

7. "The CBC's Stu Davis," Edmontonian, April 1964, 4.

8. "CKCK-AM," History of Canadian Broadcasting, Canadian Communications Foundation, http://www.broadcasting-history.ca/listing and histories/radio/ckck-am. 
It was not a particularly difficult challenge to evoke a "country" feeling at CKCK. As Wilf Collier related in an interview for the book On Air: Radio in Saskatchewan:

Our control room....was roughly nine by twelve. Everything was squeezed into that space, including two seventy-eight r.p.m. turntables. The studios were bigger. They occupied the room where the editorial staff and reporters had their 'office' space. All the walls were lined with straw pressed into bales about four inches thick with drapes hanging in front of them. This was both for soundproofing and for taking any 'hollow' sound from the room. Of course with all that straw the place smelled a bit like a stable and it also made a perfect place for mice to set up housekeeping. ${ }^{9}$

One could only go up from there. Davis started to tentatively write songs that were both naïve and derivative, but still managed to capture a bit of his personality. Both his radio and musical careers were interrupted by World War II. In 1941 he enlisted with the RCAF, and for at least part of his term was stationed at Namao Base in Edmonton. Due to an eye ailment, he was honourably discharged in 1942. That October, he returned to Regina to marry Evelyn Smith, also a singer on CKCK, and found a job as a clerk in the Bank of Commerce through 1943 and $1944 .{ }^{10}$ On weekends, he continued as a host/performer on the other station in town, CKRM, owned by the Sifton family.

After almost twenty-two formative years in the Queen City, Davis moved to Calgary in April 1945, and secured a part-time job as disc jockey with CJCJ (later CKXL) hosting a fifteen-minute daily program. He became friends with Jack Dillon, at the time a director of the Calgary Stampede. Recalled Davis:

He wanted to try something new for the Stampede that year - street singing. I agreed to be the entertainer and when visitors started pouring into the city I took my program out on the street and helped create a casual western atmosphere by inviting tourists to join in. The reaction was terrific. It turned out well for all of us and the idea is used today and still is as popular as ever. It's become a regular feature of the Stampede promotion, along with cooking flapjacks on the street and square dancing. ${ }^{11}$

He also performed regularly at such venues as the Buckhorn Guest Ranch near Pincher Creek, owned by another Stampede director and wealthy oilman Cliff Cross. The Buckhorn gig got him noticed by a movie scout who recommended that he appear as a background entertainer in the feature film Northwest Stampede. Directed and produced by Albert Rogell, and starring Joan Leslie, James Craig, and Chill Wills, it was unfortunately a 79-minute exercise in aimlessness. A positive reviewer wrote: "A thin story of a young man and girl outwitting each other in the skill of ranching and riding. Display of good

9. Wayne Schmalz, On Air: Radio in Saskatchewan (Regina, SK: Coteau Books, 1990), 14.

10. Regina City Directory, 1943, 516; 1944, 462.

11. "The CBC's Stu Davis," Edmontonian, April 1964, 4. 
horsemanship and fine horses photographed in Cinecolor; pleasant Canadian Rockies background."12 On the other hand a not-so-positive reviewer wrote:

Completely meritless Western concerning a top rodeo rider who takes over a ranch.... This is one of those films which really is terrible and dull to watch. The story and script are contrived and laboured, with nothing ever really happening.... Film is in colour, which is surprising for a Western released in 1948, although there is some really bad back projection and stock rodeo footage... 'Northwest Stampede' is incredibly tiresome with nothing for the eye or mind to lock on to for more than a couple of minutes. As a low-budget Western....with no names of any note, the film never promised much despite these low expectations the film fails in every department and has no entertainment value whatsoever. ${ }^{13}$

It did contain plenty of footage of the Calgary Stampede, however, and that was good enough for most viewers.

But it was Davis's live performances at the Stampede where he was observed by the other western Canadian legend Wilf Carter. They became close friends, and it was Carter who convinced his friends at the Chicago-based Sonora Records to sign Davis to a contract in 1946. Sonora Records was a subsidiary of Sonora Radio \& Television Corp. The record division started in 1942, at first releasing masters they had purchased from other recording companies. They started their own recording operations in February 1944, negotiating an arrangement with WOR Studios, a subsidiary of the radio station of the same name in New York City. They had as their chief clients fifteen record companies, including Key Note, Classic, Signature, and Feature.

WOR was the state-of-the-art recording studio, having opened only two years before. According to Billboard in November 1942:

The new WOR recording studios, offering the latest in acoustical properties, lighting installations and recording facilities, were completed last week. Located on the $18^{\text {th }}$ floor of 1440 Broadway, they are ultramodern in design. Walls were built with obtuse angles to control reverberation, and help eliminate reflections. Two Scully Recording lathes are located in each of the two recording rooms. An audition room is centrally located. Fourteen channels are available at all times, 10 of them located in the reference recording room. Dubbing equipment is installed in a specially designed room isolated from the rest of the studios. ${ }^{14}$

12. "Northwest Stampede," Monthly Film Bulletin 17, no. 193 (January 1, 1950): 30.

13. "Gives Cheap B Westerns of the 40s a Bad Name," IMDb, February 2001, https://www.imdb.com/title/tt0040654/reviews.

14. "New WOR Studios," Billboard, November 29, 1942, 6. 
This was a far cry from the straw-lined walls of CKCK, and Davis could rightfully feel he was about to enter the big leagues.

The Sonora label was nothing if not eclectic: they issued classical music (Havana Philharmonic Orchestra), children's songs (Uncle Don), polka (Stanislaw Mroczek and his Orchestra), jazz (Coleman Hawkins), rhythm \& blues (The Velvetones), opera (Gilbert \& Sullivan Light Opera Company), and ethnic (Lani Mclntire and his Aloha Islanders). They also started to sell country \& western recordings by such acts as Red River Dave \& His Orchestra, The Moore Sisters with the Big Buckaroos, and Jesse Rogers and the Pecos Pioneers.

Davis was fast-tracked to a recording session in New York City in September to October of 1946. He was put with a group of studio musicians known as The Northwesters, consisting of Tony Mottola (a wellknown banjo player and guitarist already on the Sonora label), Vaughn Horton (steel guitarist and member of The Pinetoppers), Bertram Hirsch (fiddle), Joe Biviano (an accordionist who, with his band The Rhythm Sextet, was also recording for Sonora), and Henry Questa (a clarinetist and saxophonist who would later join the Lawrence Welk Orchestra).

The ensemble cut eight tunes, released as "Rainbow at Midnight" b/w "The Bottom Fell Out of the Sky" in November 1946, then "I Tipped My Hat and Slowly Rode Away" b/w the awkwardly worded "I Can Beat You Doin' (What You're Doin' to Me") in December of the same year, and several months into 1947 came "Land, Sky and Water" b/w "Darlin', Now I Know the Reason Why."

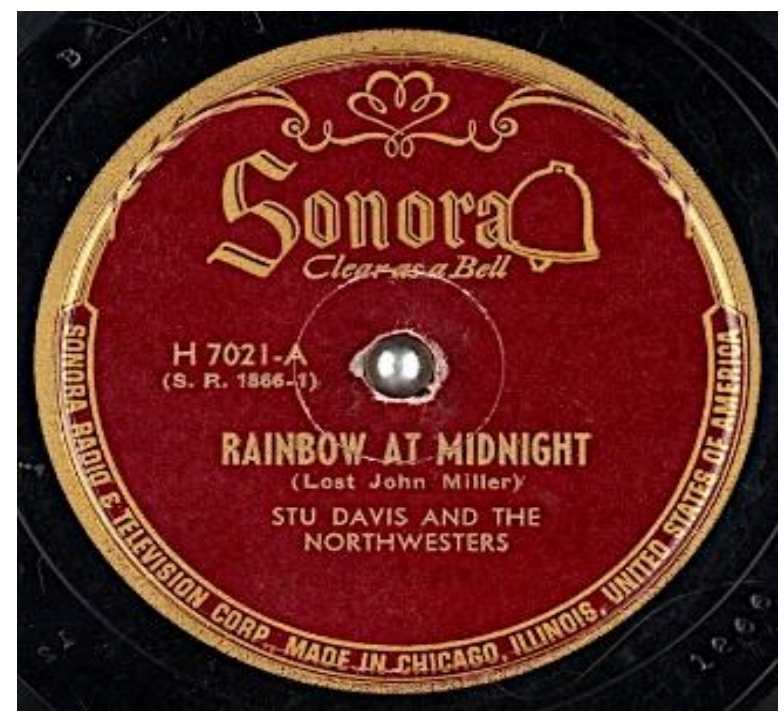

“Rainbow at Midnight" - Davis's first commercial release (Sonora Records, 78 rpm) 1946

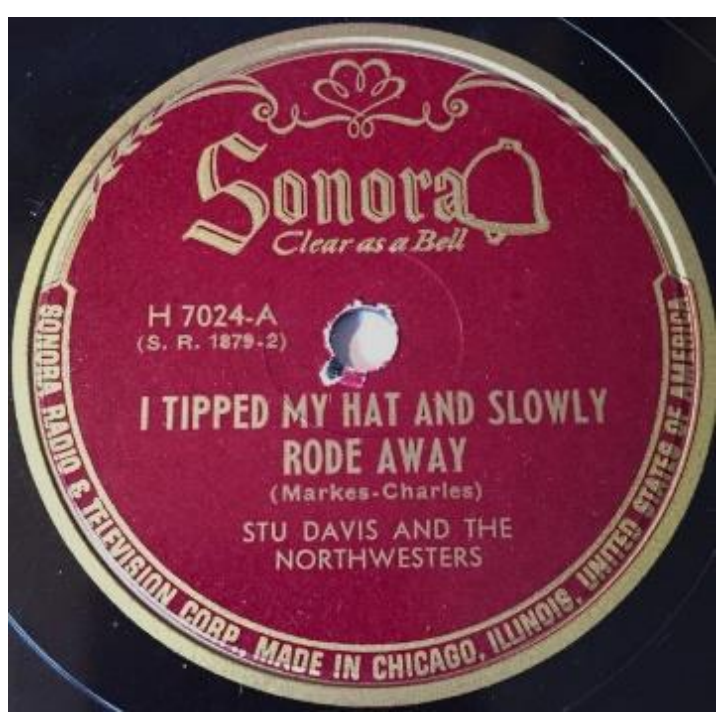

"I Tipped My Hat and Slowly Rode Away" (Sonora Records, 78 rpm) 1946 


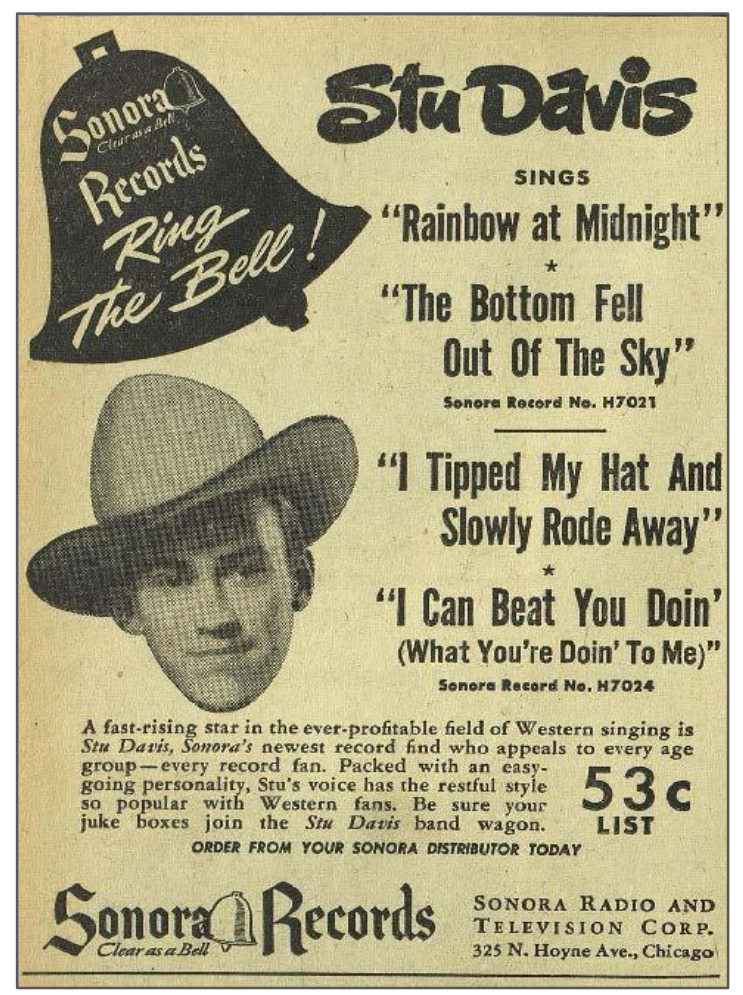

Advertisement for Stu Davis' first two 78 rpms on Sonora Records

Billboard, December 21, 1946, 18

An advertisement for his first release brought Davis to the attention of the music industry:
A fast-rising star in the ever- profitable field of Western singing is Stu Davis, Sonora's newest record find who appeals to every age group - every record fan. Packed with an easy-going personality, Stu's voice has the restful style so popular with Western fans. Be sure your juke boxes join the Stu Davis band wagon. ${ }^{15}$

Davis's timing was serendipitous. He was on the crest of a wave: the resurgence in the popularity of both western and hillbilly music following World War II. This resurgence was due to many factors, including the romanticized vision of the old west and the cowboy in literature and film. There was also the increasing public presence of "singing cowboys" like Gene Autry and Roy Rogers, as well as film appearances by such acts as Sons of the Pioneers and Bob Wills. These newer country artists, commonly known as the "Second Generation," were much more comfortable using the media, and radio in particular.

Music writers for Variety explained the growth of the wave as "large scale troop movements during the war which aided in popularizing the music of the soil." ${ }^{16}$ In other words, a huge number of soldiers in both the American and Canadian armed forces came from the western states and provinces and the rural areas. They spread their knowledge of and love for this music to the rest of the forces.

With the coming of peace, the appreciation for that music continued to spread in both rural and urban areas. In January 1947 Variety estimated that:

$15 \%$ of all major disk pressings today are devoted to folk tunes, mountain ballads and cowboy laments. Even staid New England has begun to unbend and give homegrown down-to-earth music the nod. In 1946 Boston alone bought over 500,000 platters in this category. ${ }^{17}$

15. Billboard, December 21, 1946, 18.

16. George Gilbert, “When Hub Goes for Hillbilly Airs Bet They're In!” Variety, January 8, 1947, 219.

17. Gilbert, 219. 
During his first recording session, Davis completed one of his own compositions, an indisputable classic entitled "What a Fool I Was (To Ever Let You Go)" released as a 78 rpm. Its B-side was "Crossroads" written by Red River Dave McEnery. It did not take off immediately, for Davis was still a relative unknown. However the much more famous "Tennessee Plowboy," Eddy Arnold, recorded his own version of "What a Fool I Was," and it became one of Billboard's Top Ten Tunes for 1948.

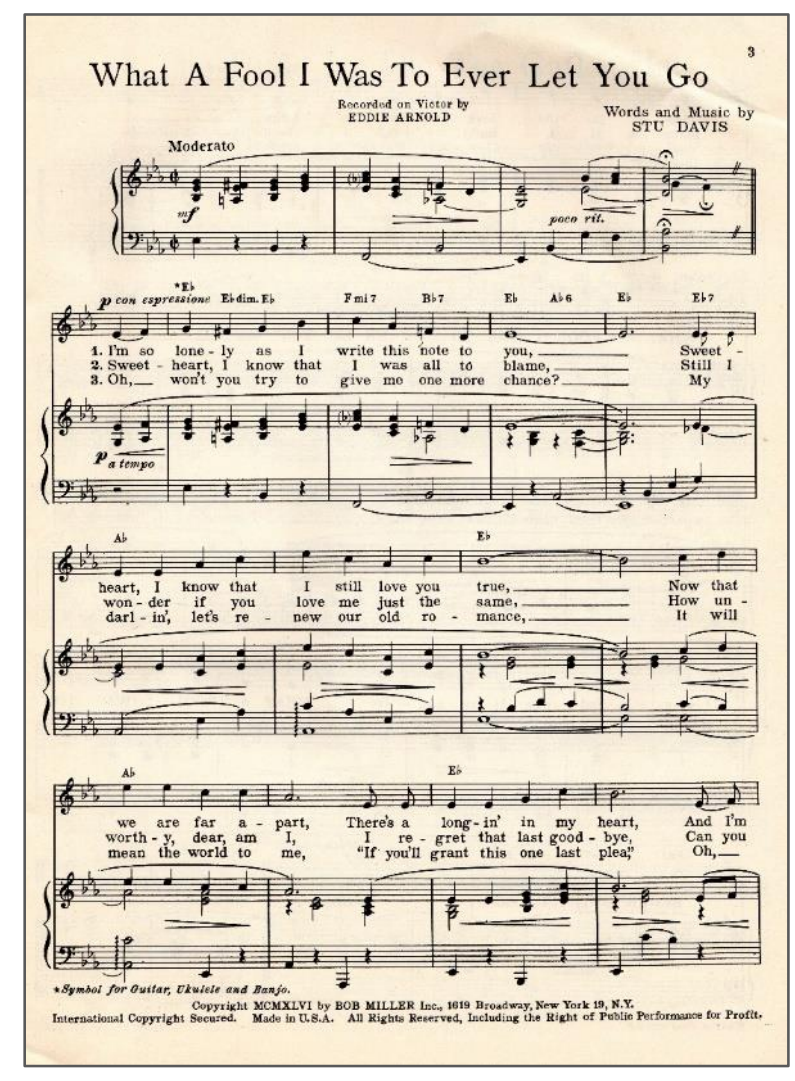

"What a Fool I Was (To Ever Let You Go)" - sheet music (New York: Bob Miller Inc., 1946)

While he may not have considered this to be one of his best songs, Davis was nevertheless fully aware that it earned him his reputation, record contracts, and publishing deals. Twenty years later, in a 1968 issue of Canadian Composer, he recounted in the column entitled "My Most Successful Work" that the song had legs:

Oddly enough, the song I have selected as my most successful work is the first composition I ever had published. In my opinion, I had written several other songs in the "country-western" vein that were superior, and have since, but this particular song which I entitled What A Fool I Was (To Ever Let You Go) happened to fall on the ear of an up-and-coming singer named Eddy Arnold, and from that day on it has been the most successful song in my own personal repertoire. 
Among the songs I recorded on my first session was the aforementioned What A Fool I Was. Eddy Arnold heard it and decided it was his type of number and contacted Bob Miller Inc. in New York who had accepted the song for publication.

Eddy Arnold recorded the song in 1948 and it was high on the hit charts for several months and was listed in Billboard among the top ten folk tunes for that year. The song has been a consistent seller ever since and has been recorded and performed regularly by other prominent artists. Just recently Eddy Arnold recorded the song again with a more up-to-date musical and vocal arrangement for inclusion in a special LP album of his biggest hits entitled One More Time.

With well over 1,000,000 sales racked up for the initial recording as a single, this re-issue in an album of Arnold's biggest sellers assures the song of even bigger sales in both the country and western and pop fields. My own recording of What A Fool I Was was instrumental in my obtaining a contract with RCA Victor and in recent years I have rerecorded it myself for a London LP entitled Stu Davis Salutes the Western Stars. ${ }^{18}$

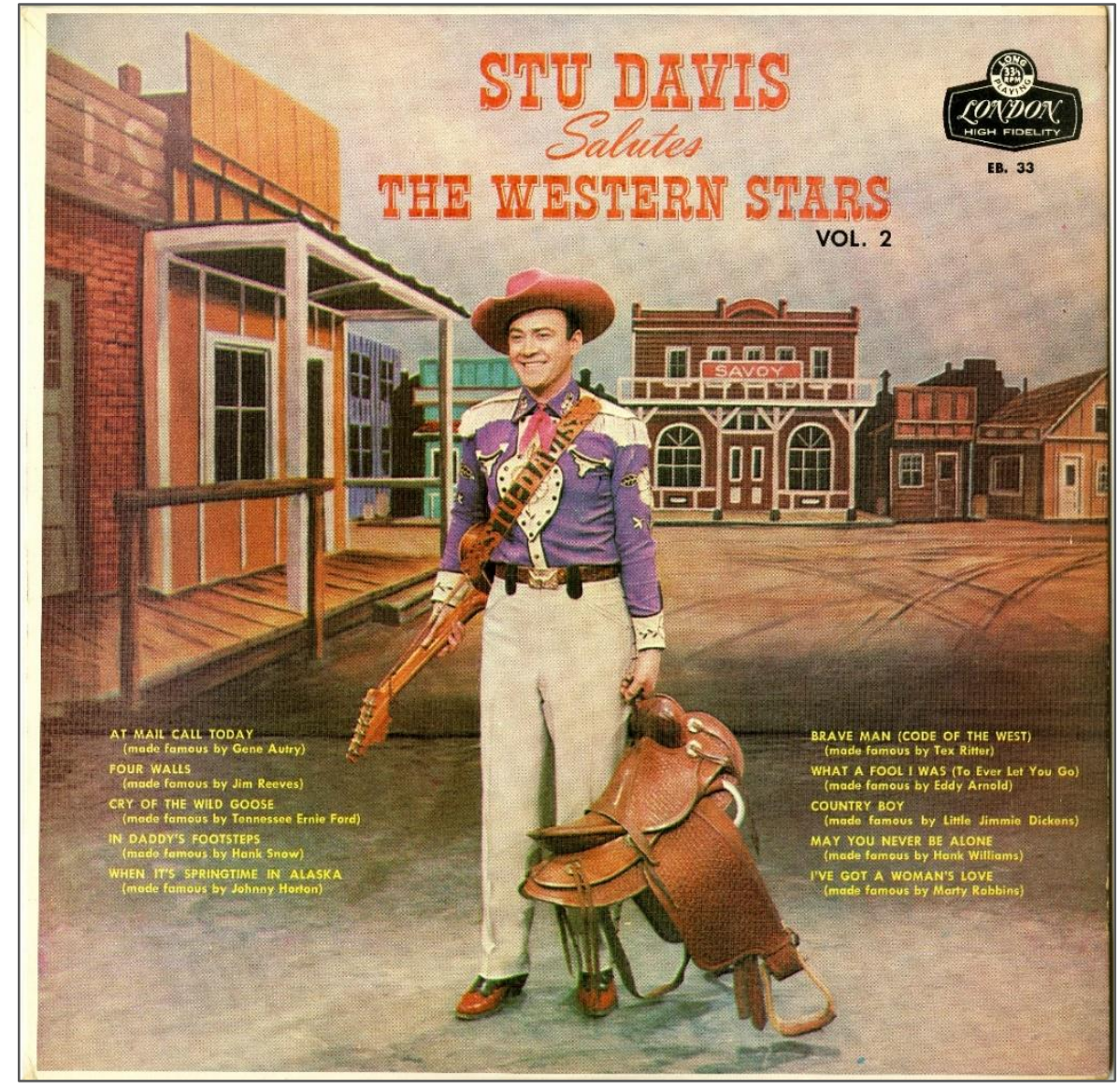

Cover of Stu Davis Salutes the Western Stars, Vol. 2

(London Records, LP) ca. 1960

18. Stu Davis, “My Most Successful Work," Canadian Composer, no. 34 (November 1968): 30. 
Davis started to write prolifically on topics both personal and universal. Though again partially formulaic, they did appear to genuinely reflect vignettes of everyday life. There were odes to his parents and family life; stories about farmers and farming; accounts of counter-culture heroes such as outlaws, gangsters, convicts and robbers; frequent paeans to the cowboy and his activities (including the rodeo); a number of religious songs (though he saved those all up for one album, The Touch of God's Hand); rounded out by the occasional novelty song for kids.

His big topic though was relationships: unrequited love, an unfaithful woman, or carrying a torch that continues to be painful. From the beginning, Davis's original "hurtin"” songs rolled off his pen easily and in large numbers. A country songwriter from this period was expected to write about heartbreak, but Davis was able to mine a large vein of relationship melancholia whenever needed. It was all the more appealing because it ran counter to his smiling and upbeat public image, and implied he had some depth. A number of his cover songs even ran over this ground, such as Jimmy Hodges's "Sweetheart of Yesterday," and Bob Nolan's "I Still Do." Perhaps Davis had had his heart broken by a Regina girl as a young man and never forgot. On the other hand, he ended up marrying his life partner, and they stayed together for more than fifty years.

His melodies were simple yet memorable. His lyrics were also simple, but included some clever rhyming, and frequently a touch of humour. The famous country music publisher Bob Miller was interviewed in 1947 about the kinds of country music that were popular in the post-war period:

"A writer must have an intimate feeling for the people he's aiming his song at," Miller observes. "It's the simple songs that sell. Most pop tunes of today are written for the top bands to play. The music is apt to be hard for the man on Main Street... he only buys the simple melodies. Most songs have too many fancy chords for the average sheet music buyer." ${ }^{19}$

He also added this oddly insightful comment:

Today a lot of people sing because they are afraid. In this atomic age, they seek an escape in church music and plain down to earth melodies such as hillbilly tunes. And the difference between a hillbilly song and cowboy number is only a ten-gallon hat. ${ }^{20}$

People wanted to forget about hard to comprehend worldwide conflict and never-ending casualties. They wanted to go back to an earlier, simpler time. Davis was able to provide this in spades.

In 1946 Davis jumped over to radio station CFCN, self-styled as The Voice of the Prairies Ltd., also in Calgary. He continued with his daily 15 -minute show, as well as a three-hour program every Friday night.

19. Gilbert, "When Hub Goes for Hillbilly," 219.

20. Gilbert, 219. 
As he did at CJCJ (and for the rest of his radio career), Stu wrote his own scripts, and often acted as producer-director.

Much of Davis's musical and broadcasting activities in the late 1940s and 1950s can be retraced from the reporting of two Billboard writers: Johnny Sippel and Bill Sachs. Both oversaw the column "Folk Talent and Tunes" in the trade magazine, and Davis's name came up frequently in company with his "Second Generation" then-peers Faron Young, Roy Acuff, Cowboy Copas, Red Foley, The Blackwood Brothers, Tex Williams, and his old CKCK buddy Alberta Slim.

In 1947 RCA Victor Records saw the positive reaction his Sonora recordings were receiving in the United States, and they offered him a more lucrative contract. As they also had better distribution and marketing than Sonora, Davis felt it was a step up, and of course he was also joining the label that had signed many of his most admired artists, Eddy Arnold, Chet Atkins, Slim Whitman, and Hank Snow. In October 1947, he returned to New York City, this time to RCA Studios at 155 E. 24th Street. This was the famed studio in which Elvis Presley and his original band would record "Hound Dog" and "Don't Be Cruel" several years later.

With his same group of session musicians (with the addition of Jim Day) Davis recorded another eight songs. Billboard gave notice of the first product out of the gate on March 20, 1948: "Stu Davis, Canadian cowboy crooner heard over CFAC, Alberta, gets his Victor Record debut with When the Snowbirds Cross the Rockies." 21

It was an odd choice for his debut RCA release. "When the Snowbirds Cross the Rockies" was written by Gene Autry (with Richard Howard and Leonard Joy). Autrey had released his version in June 1947, so less than a year had elapsed before Davis's version hit the stores. The B-side was "Welcome Back to My Heart" by Milton Leeds and Bob Miller, the famous songwriter and more importantly a music publisher Davis admired.

The next 78 release was "Too Far Apart" (a return nod to Arnold who had written it) b/w "Sweetheart of Yesterday" which was released in June 1948. Following on its heels came "Crying for You" b/w "The Dude in the Ten Gallon Hat" (a slightly sarcastic Davis-penned song about a cowboy poseur from New Jersey) in August, and "Always Keep Your Promise" b/w "I'm Gonna Leave Town" in November 1948. The latter was reviewed in Billboard. Of "I'm Gonna Leave Town" it wrote, "rhythmic rendition of novelty ditty, with spirited tenor warbling," while "Always Keep Your Promise" was summed up with "Romantic old-fashioned waltz tune is warmly warbled by Stu." ${ }^{22}$

21. "Music - As Written," Billboard, March 20, 1948, 19.

22. "Record Reviews," Billboard, December 18, 1948, 112. 


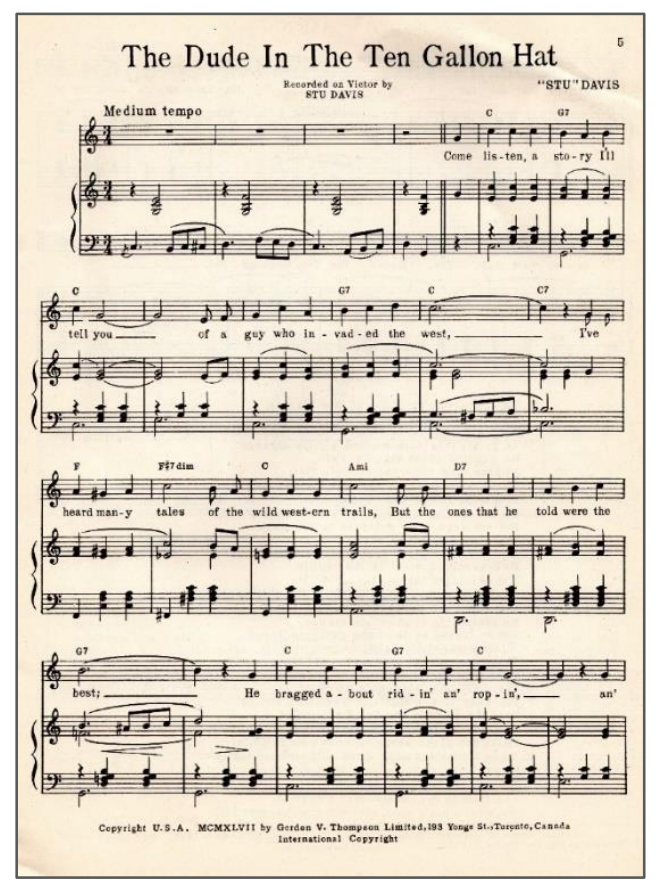

"Dude in the Ten Gallon Hat" - sheet music

(Toronto: Gordon V. Thomson, 1947)

Davis had been wise to jump off the Sonora wagon when he did. The wheels started to come off in 1948, and it was reported in the October 23rd Billboard that the company was selling some of its assets: "Rondo Records purchased 80 assorted masters, mostly hillbilly and race, from the old Sonora backlog thru Milt Benjamin. Included are sides by Bob Stanley, Jimmy and Mildred Mulcahy, Stu Davis, Snub Mosley, the Velvetones and The Moore Sisters." ${ }^{23}$ Of these, Rondo appears to have only re-released one Davis recording "I Can Beat You Doin' (What You're Doin' to Me") in 1951.

In the spring of 1948, Davis joined his third Calgary station, CFAC, another private broadcaster (Calgary Broadcasting Co. Ltd.) whose studio was located at $622-1^{\text {st }}$ Street W. His program Stu Davis Songs (sponsored by G.W.G.) aired Monday to Friday from 1:30 to 5:30 p.m. It was also picked up by his former Regina station CKRM.

Billboard reported on November 27, 1948 that:

Stu Davis, Canada's Cowboy Troubadour, who airs a daily show on CFAC, Calgary, Alta., and a daily e.t. show on five other Canadian stations, reports that he has assigned six more tunes to Southern Music and one to Bob Miller Inc. Stu's latest release on Victor is The Dude in the Ten Gallon Hat and Cryin' For You. ${ }^{24}$

23. "Music - As Written," Billboard, October 23, 1948, 41.

24. Johnny Sippel, "Folk Talent and Tunes," Billboard, November 27, 1948, 35. 
In the Fall of 1949, Davis took a short sabbatical, packed up his wife and young son Duane (born 1944), and embarked on a tour of the United States. He played a number of live concerts, but he also made a point of appearing on a number of well-known country \& western radio programs. One of the first was the Sunset Valley Barn Dance on KSTP of St. Paul, Minnesota. It was a Saturday evening show produced by David Stone, the original announcer of the Grand Ole Opry. It featured some of the more colorful (though not necessarily top-drawer) artists, like Fiddlin' Russ, Fiddlin' Hank, Cactus Slim, Six-Gun Mel, and Trapper Nash. ${ }^{25}$ Then it was on to the National Barn Dance on WLS coming out of Chicago. That station had such a clear, strong signal that it covered the entire American Midwest as well as the Canadian Prairies. It was also linked into the ABC Radio Network. Hosted by Jack Holden, it featured topline talent: Gene Autry, Homer \& Jethro, George Gobel, the Hoosier Hot Shots, and Pat Buttram (known later as Mr. Haney on "Green Acres.") Billboard announced this date in September 1949:

Stu Davis (Victor), heard on CJCA, Edmonton, Alta. is visiting the U.S., and will work the "National Barn Dance" ABC seg. September 24. Davis has been working Canadian dates with Ameen Ganum, "Canada's King of Western Swing."26

Davis arrived next in New York City and was invited onto the Prairie Pals program on WOV. This was an immensely popular six evening per week program hosted by singer/songwriter Rosalie Allen, who was also known as "The Queen of Yodeling." Finally Davis ascended the country music summit, and appeared on the venerable Grand Ole Opry, without doubt the most prestigious of the weekly stage concert broadcasts. Situated in Nashville, it began on local station WSM, went national on the NBC Network in 1939, and was heard on more than 140 stations. The performances/broadcasts moved to the famous Ryman Auditorium in 1943 and that decade saw ground-breaking concerts by Eddy Arnold, Minnie Pearl, Cowboy Copas, Little Jimmy Dickens, Ernest Tubb, Roy Acuff, and Hank Williams. It was an extraordinary achievement for Davis to be accepted on the same stage as these legends.

While he enjoyed connecting with new audiences, he realized he did not want to follow the life of a touring musician; his wife and son were his clear priority. It also became clear he wanted to stay in Canada. Following the tour, there was a huge spike in interest in Davis's songwriting by record companies, artists, and publishers. Somewhat wise now in the ways of business and not wanting to put all his eggs in one basket, Davis decided to place his original compositions with various publishers, not just one. He chose as his first Canadian publisher the well-known company Gordon V. Thompson of Toronto. He gave at least three songs to them: "Driftin' On" (1947), "You're Resting Here at Last" (1947), and "Dusty Saddle" (1947). They also issued his first collected folio of sheet music in 1948, a sixteensong set entitled Stu Davis' Song Corral.

25. "KSTP Sunset Valley Barn Dance," Hillbilly-Music.com, http://www.hillbillymusic.com/programs/story/index.php?prog=120.

26. "Folk Talent and Tunes," Billboard, September 24, 1949, 120. 


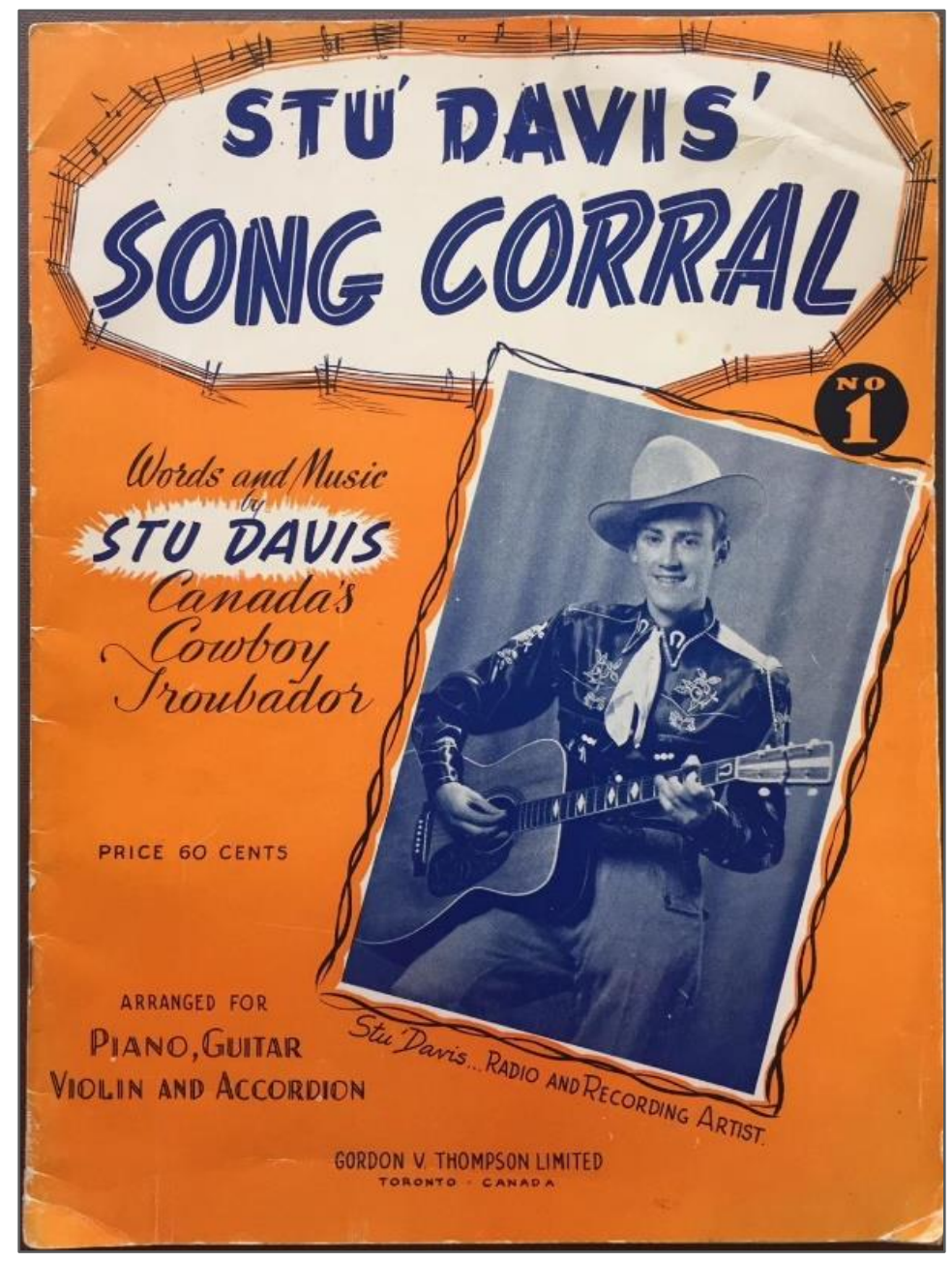

Cover of Stu Davis' Song Corral (Folio No. 1)

(Toronto: Gordon V. Thompson, 1948)

This was his first opportunity to properly introduce himself. Davis's forward-unfortunately rendered by his editors in stereotyped "cowboy" slang, started with "Well, howdy folks!":

This is Stu Davis talking to you from the old "Song Corral." I left the gates wide open so's you could come right in and sit down for a while, because I have a few things to tell you about myself...Now, I never had a chance to "toot my own horn" before, so what say we take it right from the start? - OK...I was born in the "heart of the west" and a cold part of the west - good old Saskatchewan. ${ }^{27}$ 
He explained his youthful enthusiasm for collecting songs, then:

In 1938 I started making some use of these songs. That was when I got my first chance to sing on the radio. In the years that followed I sang on several Canadian radio stations...I did some entertaining at the world-famous "Calgary Stampede" where a lot of the real bronco-bustin' boys gather. I also did a little trail riding and singing at the "Buckhorn Guest Ranch" in Southern Alberta. Around those parts I had the good luck to meet and become very good friends with a fellow named "Wilf Carter." Wilf seemed to like my singing, I guess, because he put in a few good words for me with some of the "big fellows" in New York.... While in New York on my first recording date, I met several of the top-notch recording and radio artists of today. Among those were Elton Britt, Zeke Manners, Texas Jim Robertson, Ray Whitley, Rosalie Allen, The Buchanan Brothers and the Moore Sisters. ${ }^{28}$

He ended his piece with:

That just about brings us up to date, so take a sing through "Song Corral" and tell me how you like it...So long for now and may all the trails you travel lead to happiness and success! $!^{29}$

The titles of the songs in this folio are all pure cowboy: "A Ridin' My Old Pinto," "Dude in the Ten Gallon Hat," "Dusty Saddle," "Goodnight Little Cowboy," "Just a Blue Buckaroo," "Memories of My Saddle Pals," "Old Cowpuncher," "Rockin' in My Saddle," and-licensed from Bob Miller Inc., his hit - "What a Fool I Was (To Ever Let You Go)."

Davis continued to parcel out his songs. He gave a large number to Peer International, a BMI affiliate, which was good for sales numbers, as the sheet music was published simultaneously in both New York and Toronto. They took "My San Fer-Nan-Do Rose" (1947), "Down at the End of Romance Road" (1948), "On the Trail to Your Heart" (1948), "There's a Cowboy Goin' Home” (1948), "I'Il Be Gone (When You Read this Note from Me) (1948), "Have You Forgotten?," "It Takes a Heap of Dreamin' (To Dream Your Blues Away) (1948), and "I Got Cowboy Music in My Soul" (1948).

Finally he assigned six more to Empire Music Publishers of New Westminster, BC who took "Canadian Waltz" (1949), "Tears of Shame" (1949), "In Daddy's Footsteps" (1952), "Why Should I Send You Flowers" (1950), "Deserted" (1952), and "I Looked for Love" (1952). Empire also issued his second compendium of songs appropriately entitled Stu Davis' Saddle Bag of Songs (1949). This collection contained mostly "hurtin"” songs: "Don't Kick My Heart Around," "Just as Long as You're Happy," "Never Darken My Door Again," and "Tears of Shame." However it also included two songs from Davis's roots:

28. Davis, Stu Davis' Song Corral, inside front cover.

29. Davis, inside front cover. 
"A Thousand Miles of Prairie" and "Canadian Waltz," "Alberta Cowboy," a tune intended for the Calgary Stampede, and one existential tune, "Lost on the Trail," questioning his life choices.

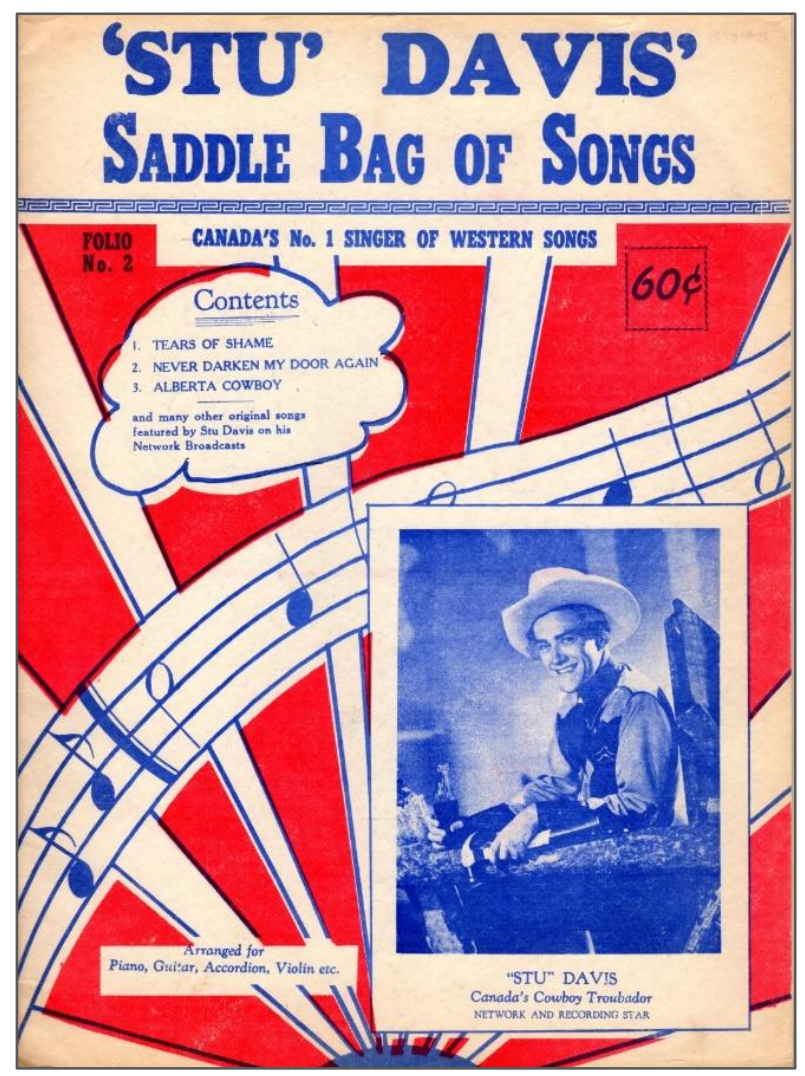

Cover of Stu Davis' Saddle Bag of Songs (Folio No. 2) (New Westminster: Empire Music Publishers, 1949)

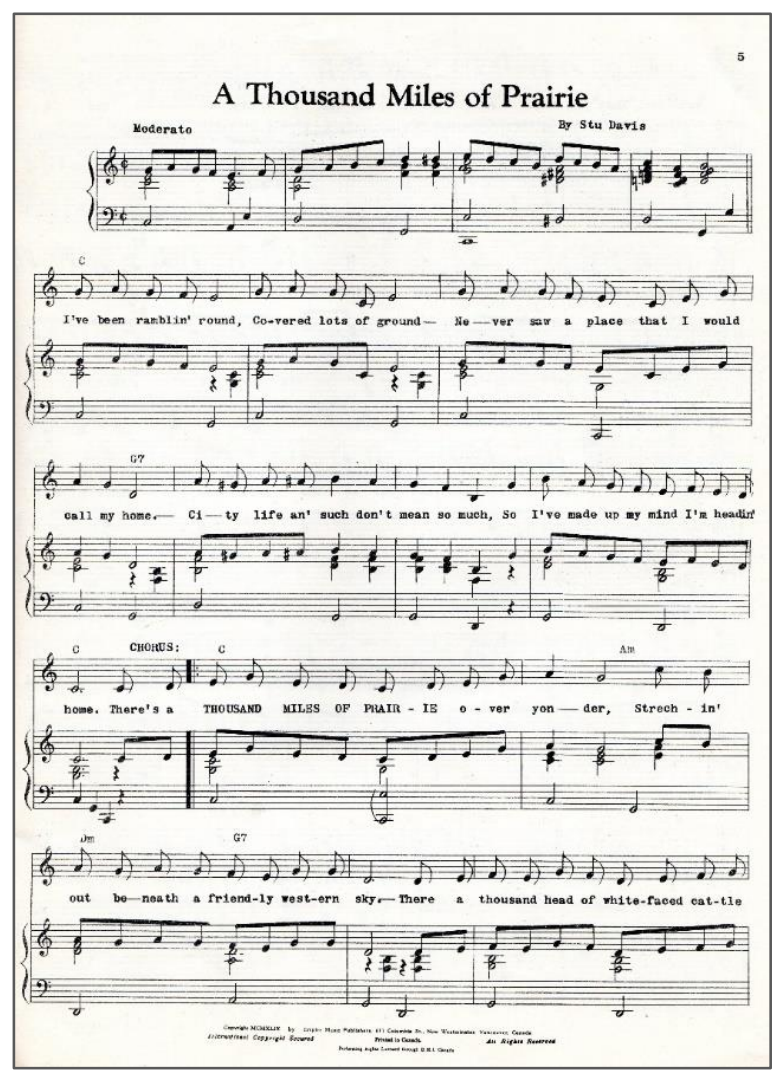

"A Thousand Miles of Prairie" - sheet music (New Westminster: Empire Music Publishers, 1949)

Davis also continued his connection with Bob Miller Inc. at 1619 Broadway Avenue in New York. Miller was founded in 1933, and the following year published Bob Miller's Famous Folio of Original Cowboy Songs. Davis had a copy as a teenager, and had always wanted his songs to be a part of this grouping. After "What a Fool I Was," he gave them "It's Just a Wild Rose That I'm Sending," "Where the Sleepy Rio's Flowing," and "Darlin' Now I Know the Reason Why," all of which were issued in 1947.

Davis's sheet music sold well. Therefore it was not surprising when Billboard's Johnny Sippel reported in his February 12, 1949 column, "Folk Talent and Tunes," that Davis had signed a number of tunes over to a relatively new company with a huge reputation:

Stu Davis, Canada's Cowboy Troubadour, CFAC, Calgary, Alta. has signed with Hill \& Range Songs Inc., which is readying a folio for release soon. Stu is lining up his Melody Wranglers band for a tour. ${ }^{30}$

30. Johnny Sippel, “Folk Talent and Tunes,” Billboard, February 12, 1949, 30. 
Based out of the Brill Building in New York City, Hill \& Range also represented songwriters such as Bob Wills, Spade Cooley, Eddy Arnold, Lefty Frizzel, Web Pierce, and in the 1950s would add Jerry Leiber, Mike Stoller, Doc Pomus, Elvis Presley, and Phil Spector to their roster.

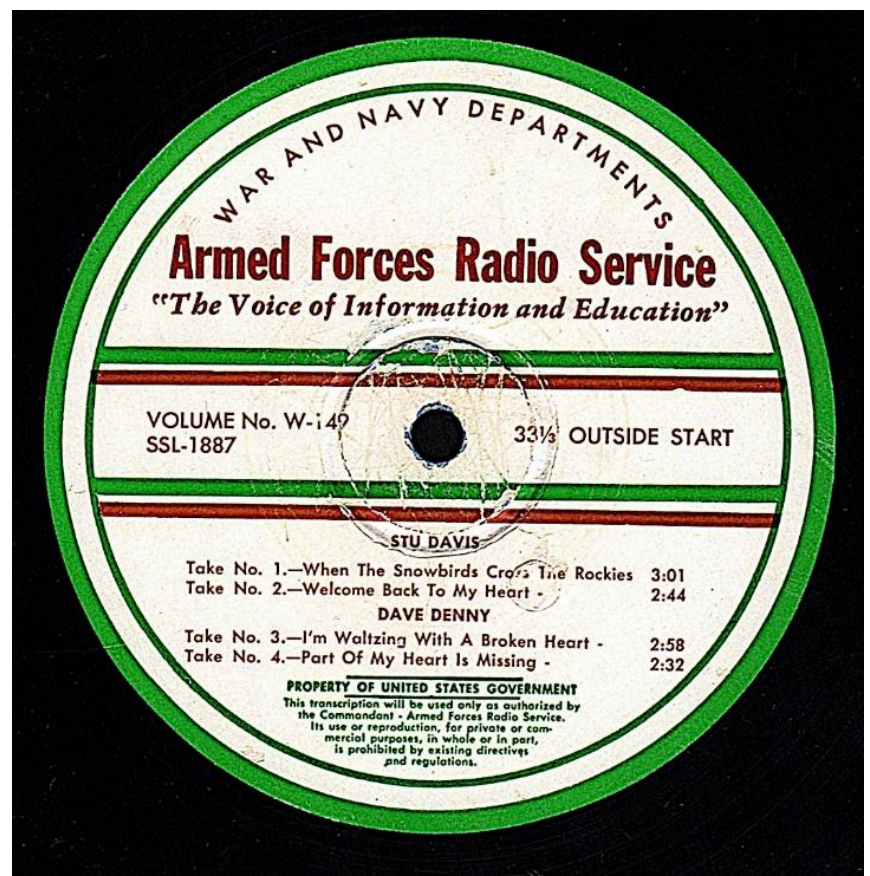

"When the Snowbirds Cross the Rockies" and "Welcome Back to My Heart" (Armed Forces Radio Service, 16 in. transcription disc) 1949
In either the last month of 1948 or more likely early 1949, Davis's radio "reach" was multiplied many times over, introducing his voice and guitar to Europe for the first time, when two of his songs were included on a transcription disc and broadcast over the Armed Forces Radio Service. This was the radio network of the American Armed Forces, a branch of the Morale Service Division. Founded by Edward M. Kirby, formerly of the National Association of Broadcasters, it began operations in 1942, providing news, PSAs, music, drama, comedy, sports, and variety programming to the US military establishments round the world, to government civilians at overseas bases, to ships at sea, and to hospitals and convalescent facilities.

The stations of the Armed Forces Radio Service started to operate first in the UK, then France, and after the cessation of hostilities, in occupied Germany. By 1945 there were more than 300 stations providing 50 hours of programming per week, 14 produced by the AFRS, and 36 re-broadcast commercially produced network shows. Military personnel were not the only listeners. Civilians on both sides of the Iron Curtain found the broadcasts to be their only reliable and up-to-date source of news and entertainment. The AFRS would continue until 1954 when it merged with the Armed Forces Television Service.

All entertainers wanted to be included in the AFRS offerings. In the field of music, the major artists of the era contributed either live performances or previously recorded tunes. Bing Crosby, Frank Sinatra, Perry Como, Peggy Lee, Al Jolson, Tommy Dorsey, Glenn Miller, and Duke Ellington were regulars. In country and western, the usual suspects: Roy Rogers, Slim Whitman, Bob Wills, Spade Cooley, and Eddy Arnold led the field. Davis's two songs were "When the Snowbirds Cross the Rockies" and "Welcome Back to My Heart," both popular RCA Victor recordings. He was coupled with another RCA country crooner, Dave Denney, who also happened to be a radio host on WHN - New York City. Denney's two songs were "I'm Waltzing with a Broken Heart" and "Part of My Heart is Missing." 
June 1949 saw Davis's third recording session, but this time he chose to stay in Canada. With a new backing group, The Melody Mavericks featuring Pat Gerow (a Hawaiian steel guitar player and part-time circus carney), Jim Day, and Fiddlin' Red Crawford (a fiddler with a solo career of his own), he completed another five tunes at the Aragon Recording Studio in Vancouver. The studio was founded in 1946 by Al Reusch, an ex-Saskatchewanian who had started his career in the entertainment business playing saxophone in a jazz big band at the Trianon Ballroom in Regina in the late 1930s. As a teenager, Davis no doubt saw him in this venue.

Touring brought Reusch to Vancouver in 1940, but tiring of the life of a musician, he moved into the radio field. After stints at CFJC (Kamloops) and CJCA (Edmonton), he returned to Vancouver in 1945 to become a disk jockey with CKNW (The Al Reusch Show) and then deejay and production manager at CKMO (Name It, Play It). In 1946 he and two partners decided there was a market in Vancouver for a recording studio: "After the war a lot of people wanted to record and send messages home," he explains. "So we rented space in an office building at 615 West Hastings and soundproofed it." ${ }^{31}$ A year later Reusch expanded his business to include his own record label, Aragon Records.

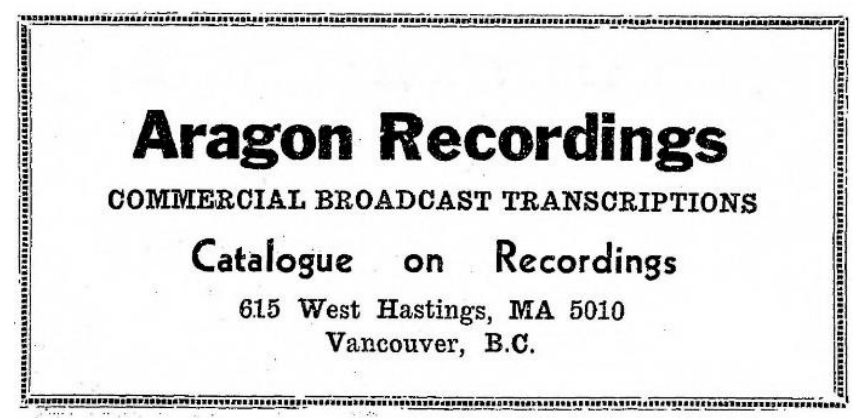

Advertisement for Aragon Recordings, Vancouver Coast News, 5 July 1951, p. 11
Aragon quickly became the most-respected label for country artists in Canada. On its roster were The Rhythm Pals, Keray Regen, Evan Kemp \& the Trailriders, Sons of the Saddle, The Peace River Rangers, Buddy Reynolds, The Calgary Range Riders, and the Tumbling Tumbleweeds. With such good company, Davis decided he wanted all of his songs recorded on the west coast to be released on Aragon Records.

Billboard reported on August 26, 1950 that "Stu

Davis, the Canadian warbler, has inked with Aragon-London label of Canada. He became father of a son recently." 32 This was his second child - Derry.

The Vancouver songs: "I Looked for Love" b/w "In Daddy's Footsteps," "Deserted" b/w "Black Mountain Rag," "Flying Enterprise" b/w "Phantom Waltz," and "I Went to Your Wedding" b/w "Why Should I Send You Flowers" were issued throughout 1952. Fellow Canadian singer Hank Snow (with The Jordanaires) recorded his own version of "In Daddy's Footsteps" in 1953, further raising Davis's profile.

Davis moved to Edmonton (as a civilian) for the first time in the summer of 1949. He was lured by CJCA to host the program Country Corral. CJCA had been broadcasting since 1922. Located in the Birks Building at 10032 Jasper Avenue, its station manager was Gerry Gaetz, who had been at CKCK in Regina when Davis got his start.

31. John Mackie, "Music Man Has Found Harmony in Life: Al Reusch, a Man of Many Parts in Western Canadian Music, Has Been Performer, Disc Jockey and Producer," Vancouver Sun, December 19, $1998, \mathrm{~B} 1$.

32. Johnny Sippel, “Folk Talent and Tunes,” Billboard, August 26, 1950, 32. 
The carrot was the opportunity to not just spin disks, but to interview visiting musicians. And indeed he did converse on-air with notables like Gene Autry, Ernest Tubb, Hank Snow, his old friend from New York Elton Britt (who was also the singing partner of Rosalie Allen), Johnny Bond, and Dick Nolan and the Sons of the Pioneers.

Billboard dutifully reported on July 29, 1950:

Stu Davis, Canada's Cowboy Troubadour, has a two-hour daily d.j. show on CJCA, Edmonton, Alta., combined with a quarter-hour live show with the Radio Wranglers, also a two-hour, barn-dance on the Alberta network on Saturdays." ${ }^{33}$

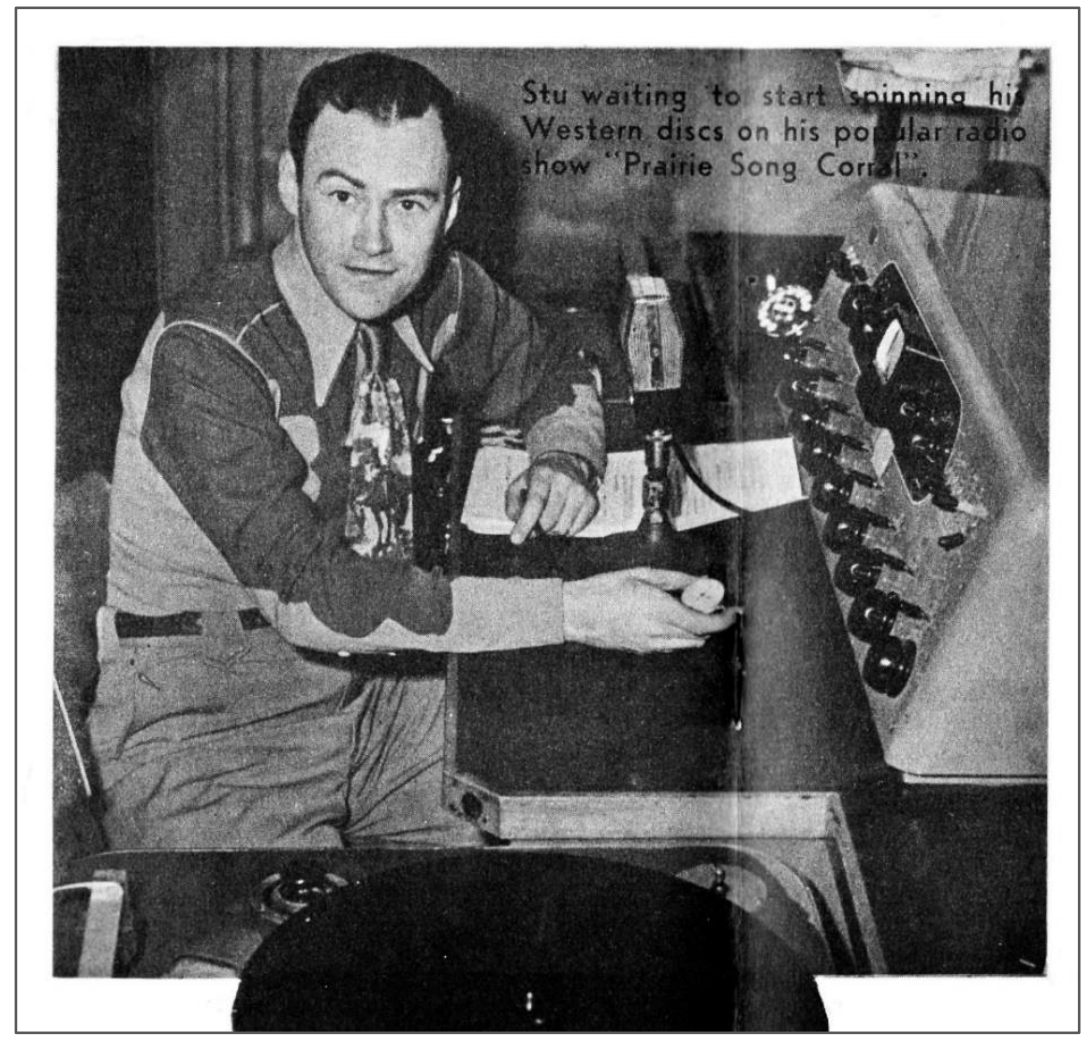

A rare picture of Stu Davis working as a disc jockey, CJCA Studio, Edmonton, 1951 From Songs by Stu Davis (Folio No. 3)

(Toronto: Canadian Music Sales, 1953)

The next set of recordings took place in Vancouver in June 1949 with Jim Day and Pat Gerow. A month later in Edmonton he also recorded two songs with accordionist Doug Goldsmith, fiddler Ted Preston, and bassist Wally McDonald, the ensemble he called the Radio Wranglers. They likely recorded in the studios of CJCA as there was no other facility in the city at the time capable of professional taping. These two songs made up his next Aragon 78 rpm, "Canadian Waltz" b/w "Child of Divorce," which came out in 1950.

33. Johnny Sippel, “Folk Talent and Tunes," Billboard, July 29, 1950, 29. 


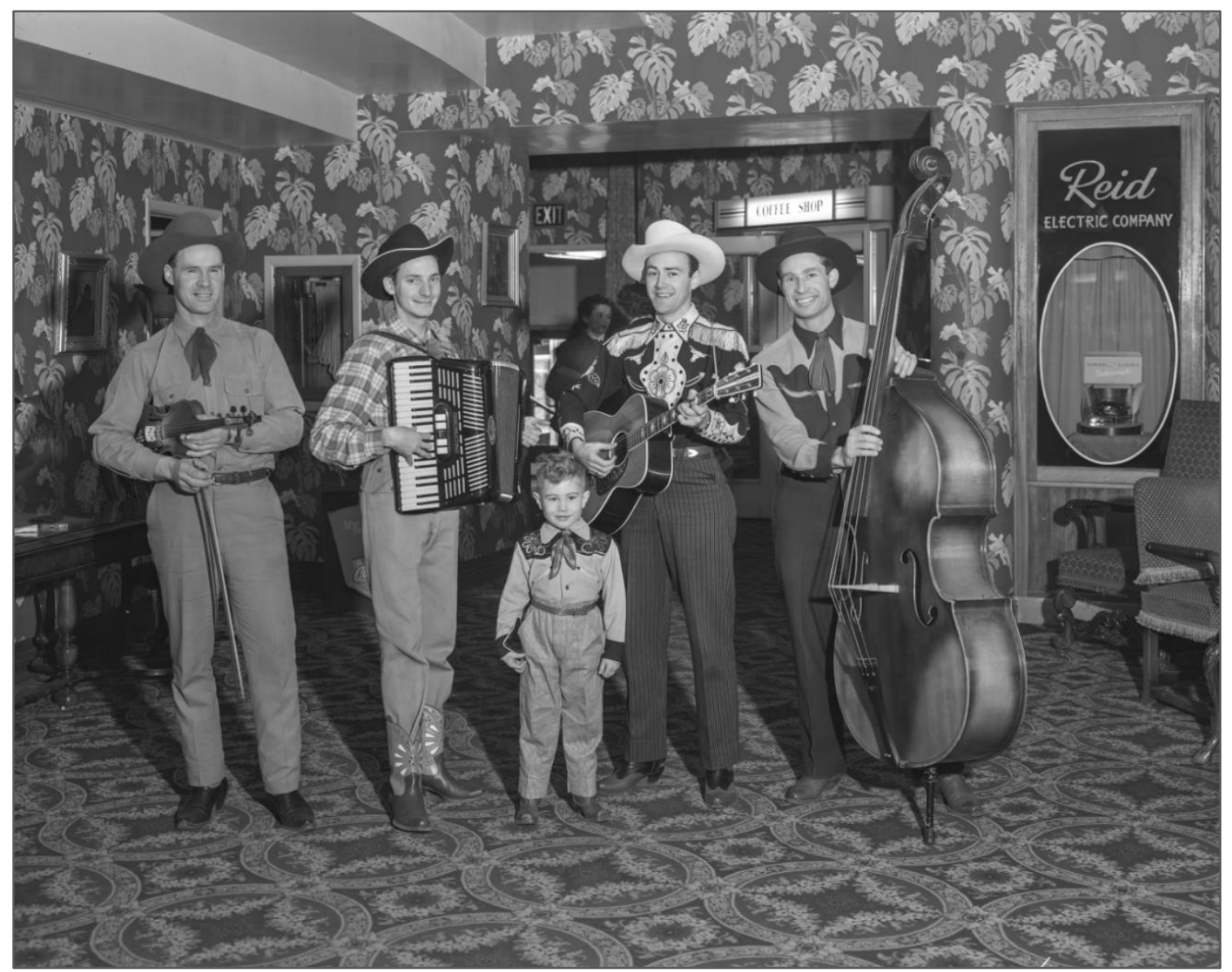

Stu Davis and the Radio Wranglers (I. to r. Ted Preston, Doug Goldsmith, Duane Davis, Stu Davis, Wally MacDonald) playing at the "Eaton Good Deed Party", Edmonton, December 1949 Photo by Alfred Blyth

Provincial Archives of Alberta, Alfred Blyth Collection, BL.1705/2

The Radio Wranglers became a real backup band, and started playing live dates around Alberta. For example they played the Stony Plain Rodeo in August 1950:

An estimated crowd of 6,000 saw Alf Neilson, Halkirk, Alta., take top saddle bronk riding honors at the Kinsmen Club stampede here. Jim Martin, Red Deer, was the winner in bareback; Albert and Alex Laye, Sounding Lake, tied in steer riding, and Alex Laye took first in calf roping. Stu Davis, recording artist, and George Welsh, trick roper, entertained. ${ }^{34}$

The Irma Times reported on Kinsella district happenings later in 1950: "Stu Davis and the radio wranglers are playing for a dance on Thursday, Nov. 30 in the Memorial Hall. Come and bring your friends." ${ }^{35}$ Another notice in a September 1951 issue of the St. Albert Gazette:

34. "Stony Plain, Alta., Rodeo Draws an Estimated 6,000," Billboard, August 26, 1950, 50.

35. "News Items from Kinsella \& District," Irma Times, December 1, 1950, 1. 
A hayride and wiener roast will be held on Sunday....The hay rack will leave from the Bluebird Café at 3:30 p.m. It is being sponsored by the CYO and all are invited to attend. Don't forget Stu Davis and his gang will be in Morinville September $21 .^{36}$

Davis switched his label affiliation to Apex Records at the start of the 1950s. The Apex label was a lowbudget, mostly Canadian label with a distinguished history. It was started in 1921 as the house label of the Compo Company, Canada's first independent recording studio and record pressing plant based in Montreal. Established by Herbert Berliner, eldest son of audio disc pioneer Emile Berliner, the Compo Co. had three other labels: Sun (for foreign releases), Ajax ("race" music for the American black market), and the forward-looking Radia-tone (recordings of radio performances, speeches and church services). It was Apex, however, that issued recordings by Canadian artists, both Anglophone and Francophone. Some of the more notable early acts included Willie Eckstein, Wilf Carter, Don Messer, Marg Osborne \& Charlie Chamberlain, Gaby Haas and the Barndance Gang, The Calgary Kid (Allen Erwin), Frankie Rodgers, and the Adanac Quartet.

The Compo family of labels became affiliated with the US label Decca in 1935, and in 1951 was purchased outright by the American company. From 1935 to 1942 the Apex label had been dropped altogether, revived only to continue releasing Canadian recordings. Apex's sales and reputation had deteriorated during the fifties, and the label was only kept alive by altering its all-Canadian status and incorporating a number of US artists. Decca was in turn bought out by the conglomerate M.C.A. in 1963.

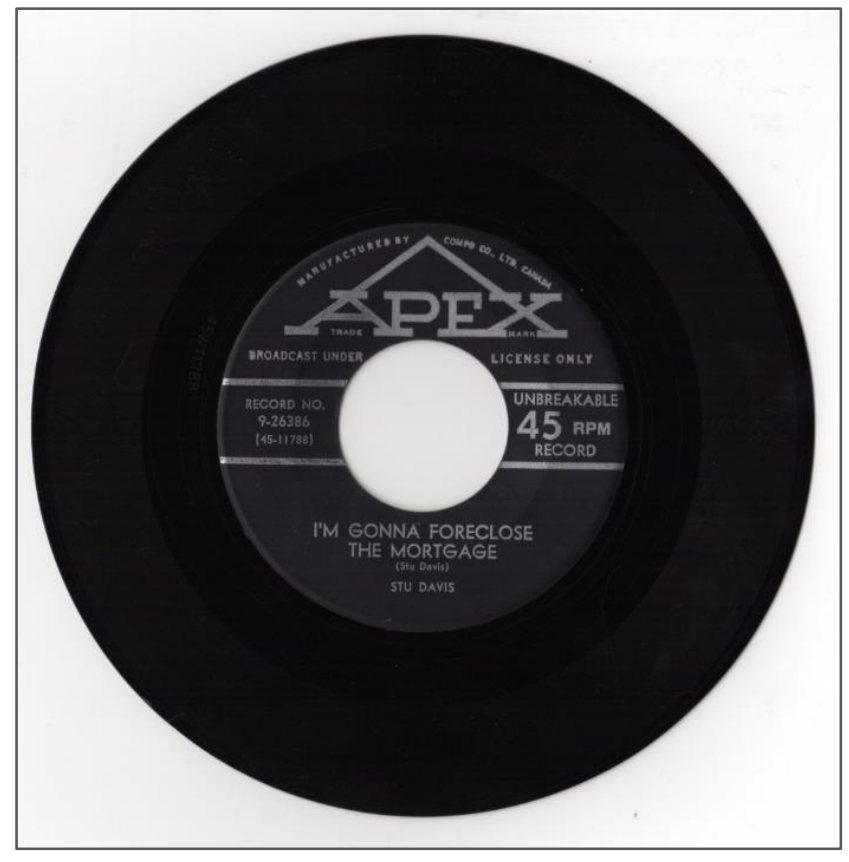

"I'm Gonna Foreclose the Mortgage"

(Apex Records, 45 rpm) 1952
Davis would release five singles on Apex, all recorded in the Compo Studio at 117 Metcalfe Street in Montreal: "Legend of the Jeebi" b/w "Parking Meter Blues" (still on 78 rpm); "I’m Gonna Foreclose the Mortgage" b/w "Three Little Secrets"; "Queen Elizabeth Special" b/w "Foothills Breakdown"; "Oil Capital Shuffle" b/w "Red Crawford's Breakdown" - credited to Red Crawford, Stu Davis \& The Cowtowners; and finally "She's Cute as a Bug in a Rug" b/w "Lovelorn Heart."

36. "Morinville News Briefs," St. Albert Gazette, September 21, 1951, 1. 
After almost four years, Davis returned to Calgary in May 1952. His entry in the Calgary directory simply indicated he was an "artist CKXL," and lived at 2608-25 Street S.W. ${ }^{37}$ This year also saw the publication of his third portfolio of compositions. It was called simply Songs by Stu Davis, and was issued by Canadian Music Sales based in Toronto. This book was a special one for Davis. Not only did it contain the sheet music for another sixteen songs, but it also included fourteen photographs of Davis at work as a disc jockey, with radio station personnel, with guests on his CJCA program, including the Sons of the Pioneers, Hank Snow, Gene Autry, two shots of Davis at home, and two shots of him and the Radio Wranglers at his farewell live performance at the Strand Theatre in Edmonton.

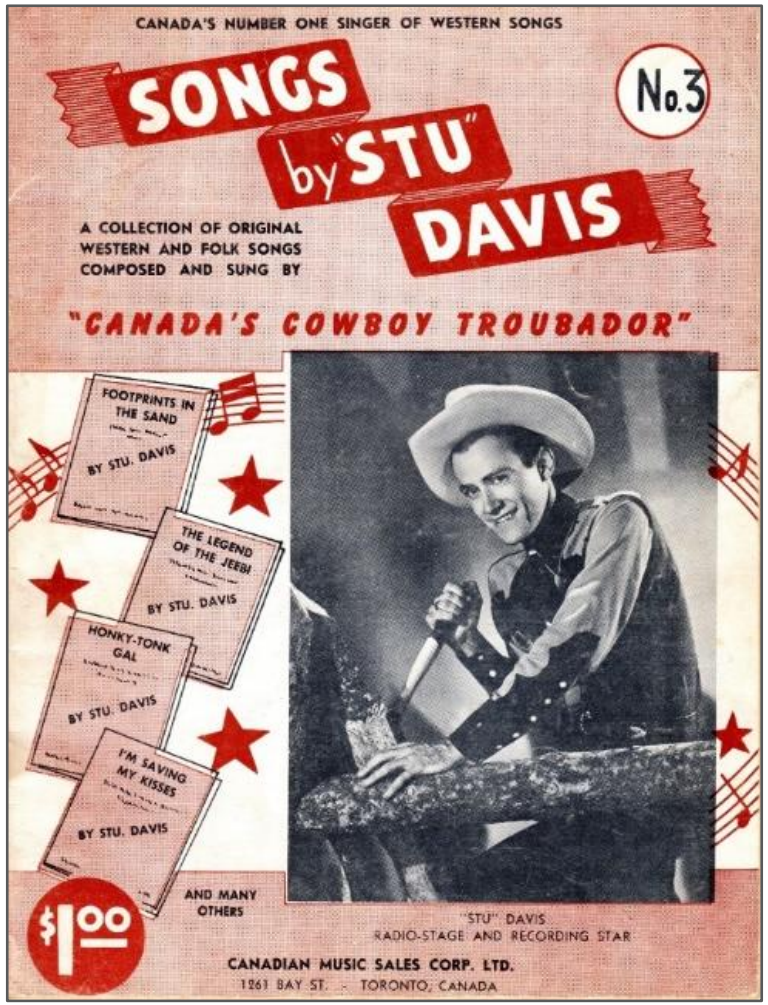

Cover of Songs by Stu Davis (Folio No. 3)

(Toronto: Canadian Music Sales, 1953)

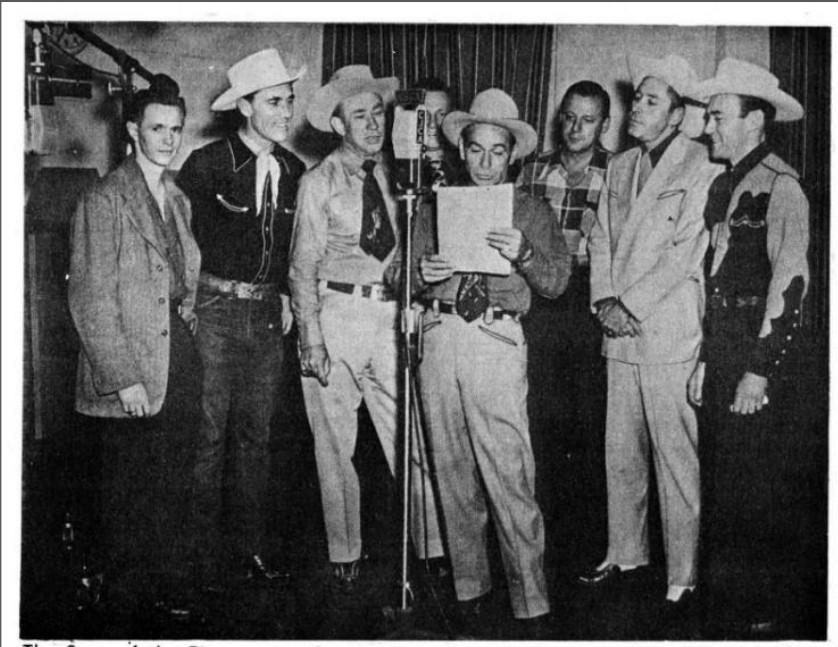

The Sons of the Pioneers as they appeared on the Stu Davis Show in Edmonton. Left to right: George Payne (staff announcer), Ken Curtis, Hugh Farr, Lloyd Perryman (behind mikel, Shug Fisher, Bob Nolan, Karl Farr, and Stu Davis.

Stu Davis with Sons of the Pioneers, in CJCA Studios, Edmonton, 1951

From Songs by Stu Davis (Folio No. 3)

(Toronto: Canadian Music Sales, 1953)

37. Henderson's Calgary Directory (Winnipeg: Henderson Directories, 1953), 1121. 
His forward again started with the cowboy affectation "Well, Howdy friends":

I've done a heap of travellin' since I last chatted with you - done a lot of stage shows throughout Alberta, and met with so many swell folks. I hope l'll be meetin' up with a lot more of you as time goes on. I'd like to thank all you nice people for buying all my latest records, and I hope you'll continue to find a spot in your own private record library for my recordings. One tune in particular that I owe thanks for is "THE FATE OF THE FLYING ENTERPRISE"...you really made it a "top" tune by requesting it on all the western radio programs - and by buying the records.

At this time I am back in Calgary the Stampede City - where I lived for four years prior to my stay in Edmonton. It's sure nice to be back broadcasting here and singing for all my old friends in the Calgary territory....here's where I hope to stay. ${ }^{38}$

He ended with: "Gotta skidaddle again friends... be seeing you again...thanks to Canadian Music Sales for doing such a swell job on this folio." 39

Included in this collection were the heartbreakers "I'll Be Glad to Forget You," "You Walked Out of My Heart," and "Roses in the Snow," but there were also tributes to his Prairie roots: "Evening on the Prairie" and "Yonder on the Rollin' Plains," two morality tales: "You Can't Buy True Love with Gold" and "Cryin' over Spilt Milk," and one religious tune: "God's Almighty Hand."

In August 1953 the CBC, in response to a pronounced audience desire for country music, launched six new radio programs "with a distinctly western flavor." ${ }^{40}$ Some aired on weekday afternoons on a threeprovince, three-station linkup ( $C B W, C B K, C B X)$, and some in the evenings on the entire CBC TransCanada network. There were two 30-minute programs: from Winnipeg came The Homesteaders with Richard Seaborn, and from Calgary, Western Hit Parade hosted by Vic Siebert and the Sons of the Saddle. The other four programs, each fifteen minutes, made up what was called The Western Roundup. They included Stu Davis from Calgary, Edwin Nylvek \& The Ranch Gang from Saskatoon, "Old Dad" Taylor \& His Orchestra from Edmonton, and rounding it out were The Rhythm Pals from Vancouver.

While happy in Calgary, Davis's stay would not last long. He was tempted in 1954 to relocate to Winnipeg to star in a networked Saturday night CKRC radio program called The National Grain Show sponsored, obviously, by The National Grain Co. This was a relatively new corporation, headquartered in Winnipeg, and trying to make a name for itself by associating with a popular radio show. CKRC was an anchor of the first ten-station western network which included CJRL (Kenora), CKX (Brandon), CIGX (Yorkton), CKRM (Regina), CHAB (Moose Jaw), CFQC (Saskatoon), CFCN (Calgary), CFRN (Edmonton), CFGP (Grande Prairie), and CKBI (Prince Albert).

38. Stu Davis, "A Letter from 'Stu'," Songs by Stu Davis, Folio No. 3 (Toronto: Canadian Music Sales, 1953), inside front cover.

39. Davis, Songs by Stu Davis, inside front cover.

40. CBC Times (Prairie Region), August 2-8, 1953, 1. 


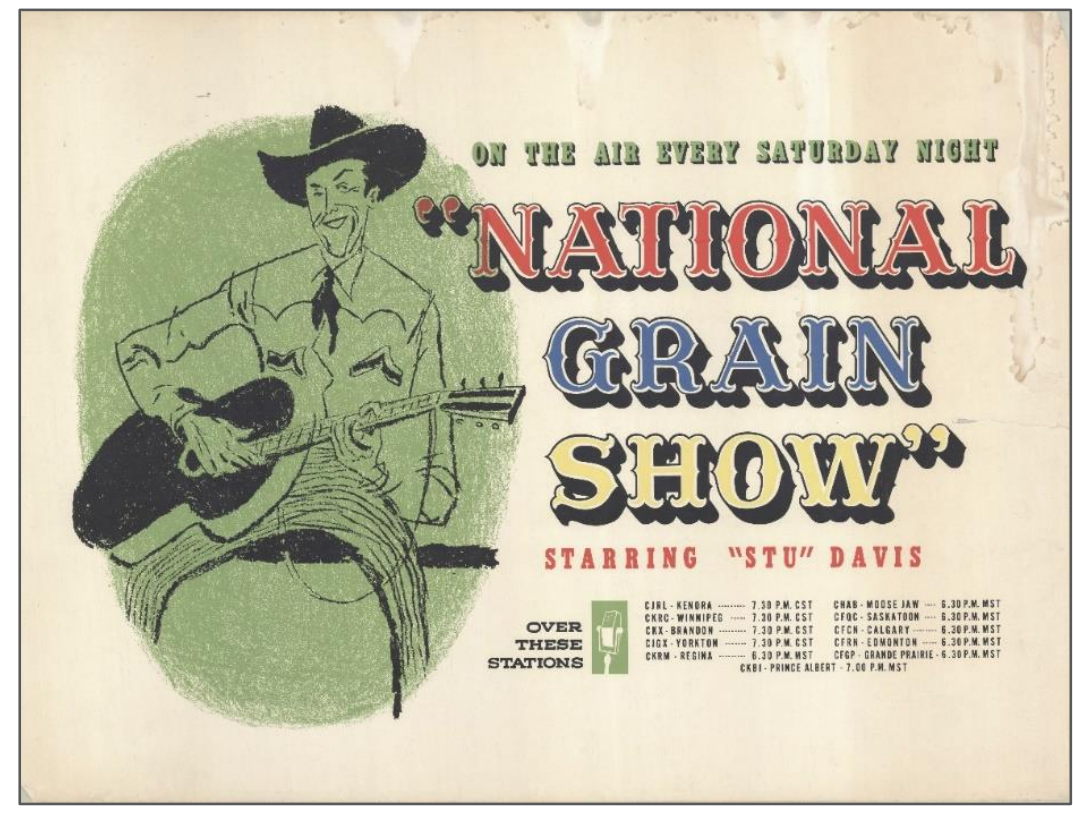

Poster for National Grain Show with Stu Davis, 1954

Provincial Archives of Alberta, Stu Davis Fonds, PR1992.0519.0062

It may seem to have been a sideways move for Davis. However, he did have a larger plan in mind. He was fascinated with broadcasting, and wanted to get in on the ground floor of the new medium of television. He wanted to be in the city which was destined to be the first Canadian television production centre west of Toronto, and that was Winnipeg. His positioning was well thought out. One year after moving there he was invited to host the first TV variety show ever produced in Winnipeg, in fact the first in CBC's Prairie Region. The next six years saw Davis work in a dizzying array of both radio and television programs, for three different and competing broadcasters, and usually simultaneously. It was an amazing balancing act.

Television would prove a tremendous boost to his career. The $\mathrm{CBC}$ was determined to establish a presence in the Prairie provinces shortly after the dawn of the new medium. As early as 1953 it started construction on a production centre at 541 Portage Avenue in downtown Winnipeg. With the call letters CBWT, it was both a carrier and producer of network programming. It went on the air May 31, 1954 in both official languages. ${ }^{41}$

A press release from the advertising agency Cockfield, Brown \& Co. dated September 22 of that year reads:

An Alberta singer has taken another step up the ladder of fame, Calgary's Stu Davis moved this month to Winnipeg, where he will broadcast a daily network program and star in an original television program.... The new network program, which will start September $27^{\text {th }}$, will be called the "Stu Davis Show" and will be heard every morning 
throughout Western Canada. It should be entertaining for those who remember the singer as a good natured Edmonton lad who collaborated with famous Hank Snow in composing a number of popular western songs. Actually Davis is a native of Regina and listeners may remember when he broadcast on a local station ten years ago. The "Stu Davis Show" will be sponsored by another westerner, Blue Ribbon Tea and Coffee Ltd. The combined interest of Stu Davis and Blue Ribbon in the Canadian West should make the "Stu Davis Show" one of the most popular on the air. "Home is where the heart is," says Davis, "and it's nice to know l'll be at home every morning in every town from Fort William to Victoria." 42

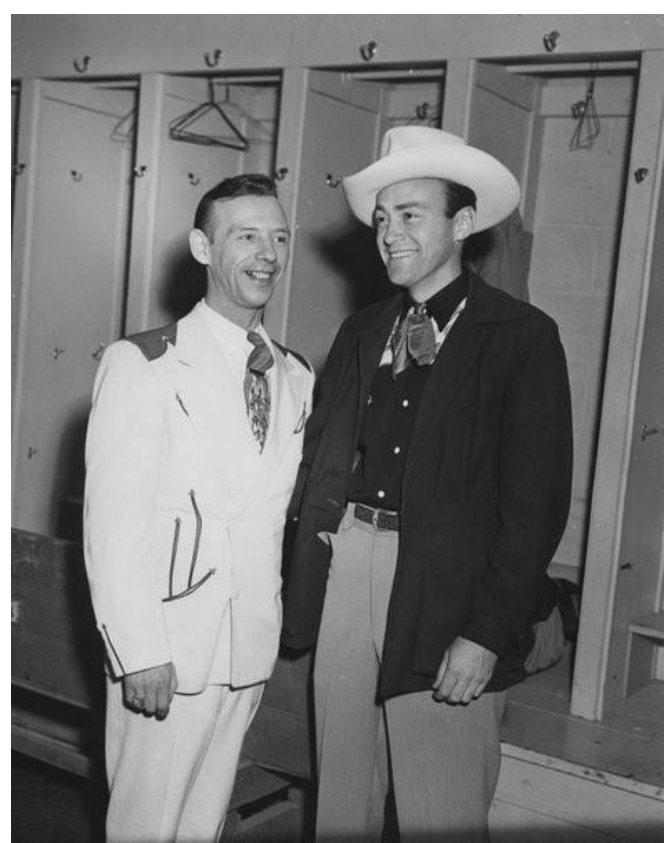

Stu Davis with Hank Snow, Edmonton, 1954 Photo source: http://studavis.blogspot.com
Billboard also announced in its Nov. 27, 1954 issue (not realizing the $\mathrm{CKY}$ was no longer the $\mathrm{CBC}$ affiliate) that:

Stu Davis, Canada's Cowboy Troubadour, has moved from Calgary, Alta. to Winnipeg, Man. where he is doing a regular TV stint over CKY. $\mathrm{He}$ is also doing a daily radio show over a network of stations, sponsored by Blue Ribbon Tea \& Coffee. The Ole Mountaineer, wellknown Canadian c\&w deejay, has replaced Davis at CKXL, Calgary. ${ }^{43}$

Davis and Winnipeg CBC-TV producer Jack Phillips started up the first incarnation of The Stu Davis Show in 1956. It would last for two seasons, and featured Davis telling stories and singing four or five songs per program. Most were covers, but he did occasionally do his own songs. It was not always a smooth transition. To go from sounding good to sounding and looking good was a new process for many radio artists, and there were no coaches. Reviews were mixed as both critics and audiences were only slowly understanding production values.

The fare on his next radio endeavour was a little more syrupy, featuring regular vocalist Alice Morrisey, with backing always provided by Monte Levine and his studio orchestra. The Winnipeg Tribune announced its inauguration on Dec 4, 1954: "National Barn Dance, starring Canada's cowboy troubadour Stu Davis and his guitar with the Monty [sic] Levine Orchestra, will be heard Saturday at 7:30 over CKRC." $^{\prime 4}$

42. Press release by Cockfield, Brown \& Co., September 22, 1954, Stu Davis Fonds, PR2332, Provincial Archives of Alberta.

43. Billboard, November 27, 1954, 16

44. "Radio Highlights," Winnipeg Tribune, December 4, 1954, 4. 
It was an experiment that did not seem to appeal to audiences, and it lasted only five months. The Tribune mentioned its last episode in April 1955: "Western singers Stu Davis and Alice Morrisey present the final program in the Barn Dance series at 7:30 Saturday over CKRC." 45

Davis then connected with his next publisher, likely the biggest of them all for country music. This was Acuff-Rose, another BMI affiliate, which was founded in 1942 by Roy Acuff and Fred Rose. Formed by two songwriters who had been badly treated by their publishers, the company became known for their fairness and honesty. They started gathering a stable of writers including Pee Wee King, Marty Robbins, and their money-maker, Hank Williams. Davis gave them at least three compositions: "She's Cute as a Bug in a Rug," "Three Little Secrets," and "I'm Gonna Foreclose the Mortgage," all of which were published in 1954.

Throughout the 1940s and 1950s Davis was happy to release his two-song 78 and 45 rpms, but in 1955 Davis heard the public's call for longer works. As well, he wanted to put out full albums. He signed with London Records of Canada, and stayed with them for more than a decade, recording more than 15 albums. Based in St. Laurent, just outside of Montreal, it had been the Canadian subsidiary of the London Gramophone Corp. since 1948. In 1954 it came under the umbrella of the Decca Record Co. Its general manager for the next two decades was Fraser Jamieson. Either Davis followed the path of most of his Aragon label mates, or they followed his, for most chose to issue their albums on London Records

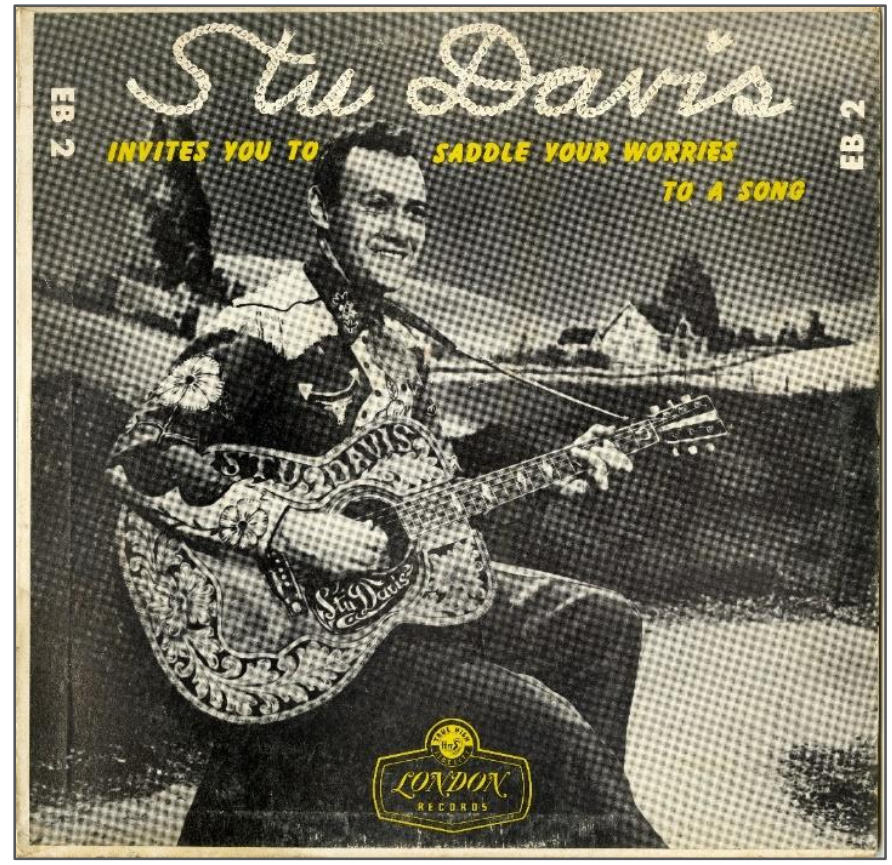

Cover of Stu Davis Invites You to Saddle Your Worries to a Song (London Records, LP) 1956 as well. His first release was Stu Davis Invites You to Saddle Your Worries to a Song. It was reviewed in the first, and short-lived, Canadian music industry magazine, Music World:

A dozen selections in various moods, served in the exclusive styling of Canada's Cowboy Troubador in tunes that make it a perfect hour's listening enjoyment. Package contains several classics as well as a good representation of Stu's own songwriting talents. Assorted topics make it an all around good buy. ${ }^{46}$

45. "Program Highlights," Winnipeg Tribune, April 23, 1955, 4.

46. Fred Roy, "Reviews and Ratings of the Latest Country \& Western Releases," Music World, July 15, $1957,29$. 
The year 1957 was an exceptionally busy year for Davis, and coincidentally was the year in which he received the most press. Fred Roy's column in Music World profiled a number of country and western disc jockeys in the July 15 issue:

Another DJ-artist amongst the top names in Canada's big family of wax whirlers is Stu Davis, who calls CBW, Winnipeg, his "home" at present. Stu has been a country music favorite as long as I can remember. He spins the discs daily over the local outlet and goes all the way. As an artist, he is currently cutting grooves on London wax with his latest offerings being l'd Be Glad To Forget You on a single disc, plus a big 12 inch LP package of hits, and he also has a live show from CBW, which is sent across Canada by the CBC hook-up. Stu formerly recorded for the Sonora, RCA Victor and Aragon labels, and as a writer, his pen has produced such well known selections as What A Fool I Was (To Ever Let You Go), In Daddy's Footsteps, Canadian Waltz, The Dude in The Ten Gallon Hat and Panama to name a few. ${ }^{47}$

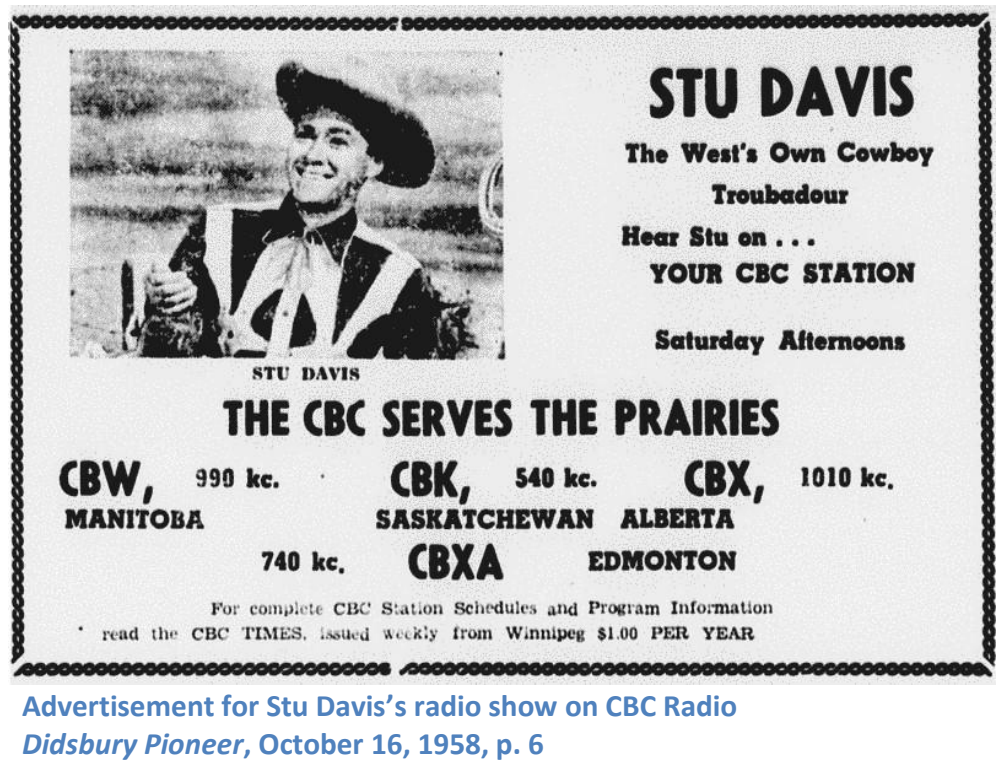

A few months later Davis was asked to simultaneously host another new television program, still in Winnipeg, entitled Swing Your Partner. It also lasted two seasons (1957-58) and was the first Canadian program to employ a regular cast of square dancers. For many viewers, Swing Your Partner was the first locally produced program of any quality. It was also the first Winnipeg-produced program to be carried on the full network. Winnipeg Free Press reporter Marion Lepkin wrote a thoughtful, and frequently sarcastic critique in July 1957. She started, as any good westerner would, with a statement of western (media) alienation:

There are occasions when the most comforting thought I can muster about a local production is to praise the lord that it is for domestic consumption only, not for export

47. Fred Roy, "Round-Up Time with Fred Roy," Music World, July 15, 1957, 32. 
to the rest of Canada. Certainly, CBC Winnipeg has produced its share of stinkers, just as other TV centres have. But like the others, it's produced some first rate programs, too. Over the years, the CBC TV network has treated the outlet here as Canada's Cinderella station - tossing most of the plums to Montreal and Toronto, and leaving the pits to Winnipeg. But I still cling to the hope that someday, somebody, will wave a magic wand and give Winnipeg equal status with her two big sisters.

For this reason, it's always with some apprehension that I tune in on a program I know the rest of Canada is going to see. I'm afraid CBWT may let us down. Wednesday afternoon, CBC Winnipeg gave Swing Your Partner to the network. And it didn't let us down. ${ }^{48}$

She continued:

It's a good show. Not that it's perfect. It isn't. But for imagination, liveliness and competence, it has it all over most of the Woolly West shows CBC has turned out. In fact, I can think of only one to match it, and that is the long-defunct Burns Chuckwagon Show from Vancouver.

The success of Swing Your Partner surprised me. Stu Davis, "the cowboy troubadour" was billed as the singing storytelling host and this fact stirred up no enthusiasm on my part. His earlier series - The Stu Davis Show - was a tedious, long-winded, monotonous effort. Fifteen minutes was just too much for him to handle alone. But on Swing Your Partner, Mr. Davis has found his niche. He doesn't have to go it alone. He has other performers with whom to share his obvious enjoyment of western songs and he performs better working with others. The viewer is better off too. There's more variety and there isn't time to be bored.

But the outstanding thing about the new program is its staging - fluid yet patterned: smooth but not stiff: lively yet under control. Producer Len Weinstein has managed to find a perfect group of square dancers, not too polished, but agile and handsome. And their performances beg for some overhead camera shots so that we can see the pattern of the dances. Mr. Weinstein has not only provided fine performances, he's also introduced a little historical material as well - anecdotes based on research by Hart Bowsfield [then the Provincial Archivist of Manitoba]. By using the stories, paintings, still photographs and some delightful sketches by Bruce Head [then CBC graphic designer and later nationally known painter]...the producer has introduced a brightness and breadth not usually found in a program of this kind. ${ }^{49}$

48. Marion Lepkin, “Lively Partners, No Rumpus,” Winnipeg Free Press, July 6, 1957, 31.

49. Lepkin, 31. 
She saves her main criticism for the end:

The only really sour notes are the colloquialisms Mr. Davis insists on throwing in to prove this is an honest-to-goodness "western" show - the I-hope-you-have-a-heap-offun" and the "I'd kinda-like-tah-tell-yahs." These stand out like a sore thumb in a show which has finally managed to capture a prairie flavor without making us all out to be a bunch of dim-witted, bow-legged morons. It would be pleasant if Mr. Davis talked as if he belonged here. ${ }^{50}$

It is hard to fault Lepkin for pointing this out. Davis's recorded work shows that he never sang with a twang, and never talked like a Texan in his real life.

All the while Davis continued with his Saturday radio program, and if that was not enough, he started to guest star in other CBC television programs. One in particular was Cliff McKay's Holiday Ranch variety show which was broadcast from Toronto from 1953 to 1958. Its set was a faux ranch house, and although country music was its main offering, it also featured comedians and folk artists. It appeared on Saturday evenings and received high viewership ratings, likely because it preceded Hockey Night in Canada. Davis appeared three times: November 24, 1956 (singing "Wild Weed"), June 1, 1957, and September 20, $1958 .^{51}$

Fred Roy, writer for Music World, likely had the most comprehensive overview of the state of Canada's country music community and its place in the wider world. He attended the Sixth Annual Country Disclockey Convention (and the $32^{\text {nd }}$ Anniversary of the "Grand Ole Opry") in Nashville in November of 1957. This was the impetus for a lengthy and wide-ranging article later that month. He synthesized a history of Nashville, its artists, publishers, and recording studios, the radio show/cultural event, and then profiled a number of people who had brought it all into being.

He then wrote about the other country music radio and television programs both in the US and Canada:

Canada also has a crop of similar shows, such as Hamilton's "Main Street Jamboree" at CHCH-TV; Toronto's "Country Hoedown" and "Holiday Ranch" shows out of CBLT-TV and the CBC Network; and "Alberta Ranch House" coming out from Edmonton, Alberta. All try to model their programs on "Grand Ole Opry", but there is only one "Opry" ...52

He then turned to the artists:

Canada, too, has her leaders among the country music performers, and like their former Canadian colleague Hank Snow, their lifelong ambition also is to someday become a "Grand Ole Opry" star. Canada has produced many great artists in the country field,

50. Lepkin, "Lively Partners, No Rumpus," 31.

51. "Episode Guide - Holiday Ranch," TVarchive.ca, http://www.tvarchive.ca/database/17268/holiday ranch/episode guide/.

52. Fred Roy, "Canada Salutes Nashville - Music World Special," Music World, November 1957, 23. 
some of them having received national recognition for their efforts. Canada can point with pride to such artists as Stu Davis, Jack Kingston, Wilf Carter, Myrna Lorrie, Earl Heywood and Bob King, etc. Others who have not yet reached such high standards but show every promise of doing so include such performers as Tommy Hunter, Ron Scott, Buddy Reynolds, Terry Parker, Red Monroe, and Keray Regan as individuals and such outstanding groups as Chuck Fortune's "Chuck Wagon Ramblers", Even Kemp's "Trail Riders", Slim Boucher's "Golden Prairie Cowboys" and Vic Siebert's "Sons of the West." 53

The fourth published compilation of Davis's songs came out in 1957. To drive home his connection to the broadcast media, it was entitled Stu Davis Radio and T.V. Song Book, and its 16 tunes were published by Gordon V. Thompson. It is probably his most interesting collection of songs. There are the expected melancholic country songs, "Unfaithful Woman," and "You've Worn Out Your Welcome," but there is also one obviously designed for airplay, "Dear Mr. Disc Jockey," and one "Honky Tonk Serenade," whose tempo instructions read "Medium Rock and Roll Rhythm." There are also further indications of Davis's quiet religious foundation, "Listen to the Voice of the Lord" and "Shepherd of Mine," and finally his first co-write, "Little Crushed Roses" with Bob Bruce.

In the forward to the Song Book, Davis brings his followers up to date (with the least "twang" of all his introductions):

This is your ol' Cowboy Troubadour back again with another brand new folio of songs. These songs are some of my biggest request numbers on my CBC radio program and my TV shows. I thought I would select the best of them for this book, and I hope you enjoy singing them as much as I do. Some of the songs are on the London label. If you are a record collector, perhaps you will add them to your collection.

Well since my last visit with you via the pages of a song book, I have done quite a lot of travelling. At the present time I am located in Winnipeg, where I do my radio and TV shows for the Canadian Broadcasting Corporation. I have my wife, Evelyn, and my two boys, Duane and Derry, with me, and we are making this our home for a while.

I would like to express my heartfelt thanks to all you nice fans who have been so loyal to me during these past years. Your letters and comments on my efforts are greatly appreciated, believe me. I hope you will always find time to tune in to my broadcasts and to find room on your record shelves for a few of my records. ${ }^{54}$

53. Roy, "Canada Salutes Nashville," 23.

54. Stu Davis, Stu Davis Radio and T.V. Song Book (Toronto, ON: Gordon V. Thompson, 1957), 2. 
He mentions a fan club:

A new STU DAVIS FAN CLUB has been organized, and I would like you all to join. For full particulars, just write to the club president, Lorraine Belford, 476 Home Street, Winnipeg 10, Manitoba. The dues are only $\$ 1.00$ a year, for which you receive four journals containing all the latest information and news on "Yours Truly" - write-ups on other radio, TV, and record artists - words of various song favorites - and all other club privileges. ${ }^{55}$

He ended with his by now famous line: "May all the trails you travel lead to happiness."

Davis's next television program was a summer 1958 replacement. As described in the Winnipeg Tribune's "Worth Dialing" column:

Winnipeg troubadour Stu Davis will start working before CBWT cameras again when he swings into a summer series July $1^{\text {st }}$. Tabbed Out West, the program is set to run for 13 weeks. Kerry Wood, who hosts the Outdoor series for radio (Saturday - CBW) will be the writer of the teleseries. ${ }^{56}$

That was followed by Rope Around the Sun (1958-59), a CBC afternoon show combining storytelling and songs for children. Ann Henry's column "Report on TV" in the Winnipeg Tribune of July 11, 1958 commented:

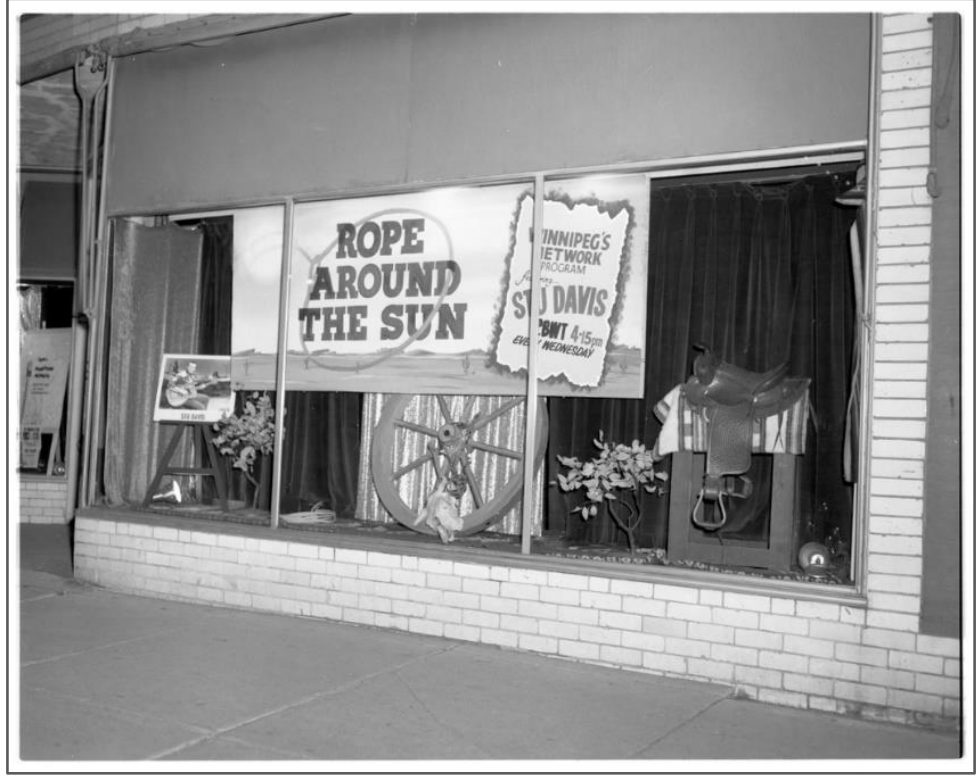

CBC display window on Portage Avenue, Winnipeg, promoting the television program Rope Around the Sun, 1958

University of Winnipeg, Western Canadian Pictorial Index - Canadian

Broadcasting Corporation (contact sheet \#A1493, image \#45164)

55. Davis, Stu Davis Radio and T.V. Song Book, 2.

56. Carole Kowalson, “Worth Dialing," Winnipeg Tribune, May 14, 1958, 32. 
It'll be cowboy week in television this week. Not only will there be a new series for children, Rope Around the Sun with Stu Davis, which will tell cowboy stories while Stu sings; there'll be the Calgary Stampede and of course the usual roster of western programs making it look as if the whole network has gone western. From CBC Winnipeg, and on the network, Stu Davis tells how the Stampede began back in 1912. He will sing songs about The Stampede and Pete Knight's Last Ride. Subsequent programs will tell about Cowboy Cooks, Wild Horses and The Mad Trapper. ${ }^{57}$

Davis dipped a tentative toe in the genre of rockabilly at the end of the 1950 s. The Tribune mentioned in January 1959:

Broken Love, a ballad written, arranged and vocalized by local talents, may hold new horizons for the group if its recording by a New York firm clicks. CBC stage hand Don Tomiuk penned the song in collaboration with Elmer Sexsmith and pianist George Reznik a year ago. Now put to the beat of rock n' roll, the new version will be premiered by Stu Davis on next week's Saddle Songs. Davis and a vocal group made the recording for London Records of Montreal a month ago and from there it went to New York. The boys, who are working on other songs, report this may be the door-opener for them. ${ }^{58}$

It was issued as a single, but despite all the local excitement, it does not appear to have opened any doors, or even charted. Davis made one last attempt at sort-of rock music with his recording of "New Broom Boogie" written by Al Dexter and Cindy Walker, and originally performed by Al Dexter \& His Troopers. It was a standout number with the guitar work showing the clear influence of Scotty Moore. However it was never released as a single, and got buried on the Rope Around the Sun album.

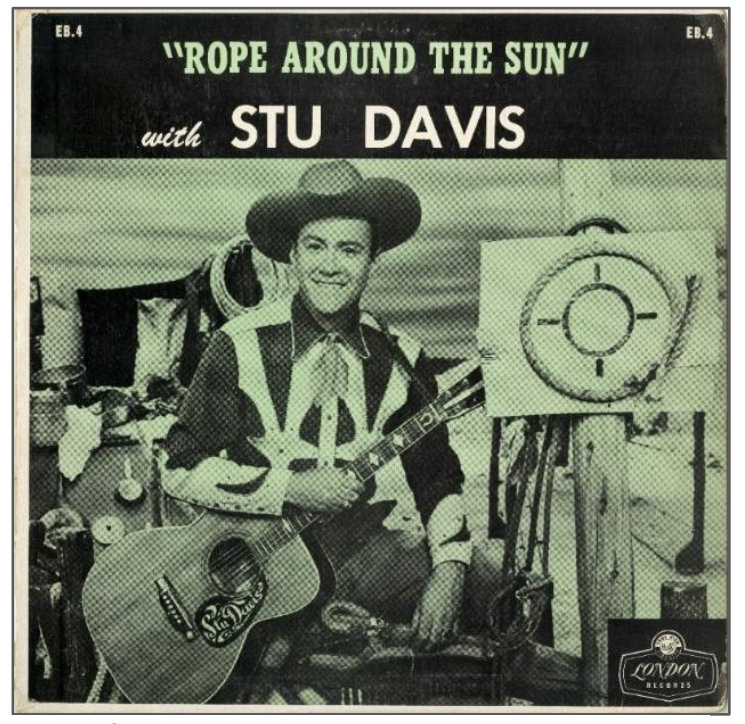

Bill Sachs of Billboard thought Davis's next album was worth a mention in his column of June 29, 1959:

London Records of Canada has just released a new long play package by Stu Davis, of Winnipeg, Man. Named after his TV show "Rope Around the Sun", which resumes on the CBC-TV network July 8 , the album contains 10 selections, including "Ripple River", The Rose Upon the Bible" and the title song. Some of the tunes were penned by Stu himself. Davis has been a country music favorite in Canada for many years. ${ }^{59}$

Cover of Rope Around the Sun

(London Records, LP) 1959

57. Ann Henry, "Report on TV," Winnipeg Tribune, July 11, 1958, 3.

58. Carole Kowalson, "Worth Dialing," Winnipeg Tribune, January 16, 1959, 8.

59. Bill Sachs, "Folk Talent and Tunes," Billboard, June 29, 1959, 7. 
In November 1959, CBC briefly brought back The Stu Davis Show:

Stu Davis show replaces Football Huddle when that show closes for the season. Davis will have more people on the show, including a vocalist Berni Garrison (she's a girl) and a trio called the Tumbleweed Trio; they are Jimmie Pirie, Irwin Wall and Carl Asplund. ${ }^{60}$

One of Davis's true radio highlights for 1959 was the appearance of the country humour duo Homer \& Jethro on his radio show in December. As The Tribune reported:

Stu Davis, foreman of the CKY Ranch House has Homer and Jethro, who have been appearing at the Rancho all week, as guests on the Western Hit Parade at 9 p.m. Stu Davis can also be heard from 4 to 5:30 p.m. each afternoon on CKY, when he features some of his own songs. ${ }^{61}$

For all his success up to this point, his huge breakthrough came when he started hosting yet another new Winnipeg program called Red River Jamboree in 1960. It was another summer replacement show, and was such a hit that it was subsequently inserted into the Fall/Winter season. For five years, it would be the most popular show on CBC coming out of the Prairies. Produced by Ernie Mutimer, it was, according to one source, slightly unorthodox for the time: "More than a studio-bound program of country and western music, the program framed music with stories of Canada's Old West, and included film sequences shot at a ranch established at the turn of the century to lend the show authenticity." 62

The Winnipeg Tribune introduced him again to the viewing public on July 1st:

Stu Davis, Winnipeg's cowboy-troubadour, has come a long way from collecting ballads and songs as a youngster in Regina. He's host of Red River Jamboree which replaces Country Hoedown on the network for the summer months, starting Friday July $8^{\text {th }}$. Stu has had two other successful shows which concluded after 39 programs instead of the originally scheduled 13 week run. They were Swing Your Partner and Rope Around the Sun.....63

Davis was the singing host, and alternated with vocalist Peggy Neville, a four-man group called the Altones, and a troupe of eight dancers known as the Valley Beaux and Belles. Backing up everybody was an ensemble of Winnipeg musicians called The Selkirk Settlers, who would go on to become notable session players. The leader, Ted Komar, was joined by Mitch Parks (piano), Paul Olynyk (bass), Clelio Retaghatti (fiddle), Wally Diduck (fiddle), Irvine Wahl (guitar), Monte Levine (guitar), and Reg Kelln (drums). The Settlers also featured a young whiz-kid on guitar named Jimmie Pirie. Davis was inspired by his fretwork and wanted to work with him beyond the confines of the program. Pirie was asked to guest

60. Ann Henry, “People," Winnipeg Tribune, November 24, 1959, 22.

61. "Featured this Evening," Winnipeg Tribune, December 14, 1959, 24.

62. "Red River Jamboree," TVarchive.ca, http://www.tvarchive.ca/database/18280/red river jamboree/details/.

63. Winnipeg Tribune, July 1, 1960, 8. 
on several of Davis's albums, and Davis even "sponsored" him on the London Records LP called Stu Davis Presents Jimmie Pirie's Guitar-ama.

An almost complete episode guide to Red River Jamboree exists, and gives rare insight into a Prairie variety show. Guests included a teenaged Lenny Breau, early rocker Ray St. Germain, Reg Gibson, George LaFleche, Wally Koster, the Mercy Brothers, Stu Phillips, Jack Paget, Donna Aubert, and Marian Breitman. Many of the episodes were thematic, and some of these include the story of beef cattle and brands, the western movie, Prairie summer, pioneer trails, the fur traders, gentlemen cowboys, the boom town, wagon trails, the Red River Exhibition, and a special presentation at the November 1960 Grey Cup in Vancouver. ${ }^{64}$

Jerry Lee in the Winnipeg Free Press column "Speaking of Television" gave it a mixed review in May 1960:

Red River Jamboree is like a wedding of Rope Around the Sun, and Saddle Songs. Its lack of originality, however, has not prevented it from being the best musical produced at CBWT this year. That's not saying much, I know. But the show has, in a lively simple way, achieved some measure of success which can be largely attributed to Stu Davis. Stu has learned the secret of being an attractive TV personality - be yourself. Be yourself, because the TV camera is like a magnifying glass which shows up the phoneys. The sincerity and easiness with which Stu presents himself has rubbed off on others in the Jamboree cast. There isn't nearly as much of the eager-beaver, forced atmosphere which has plagued other locally-produced musicals.

Musical background supplied by the Tumbleweed Trio is pleasant enough. The switch to western pace has been good for the Altones who seem relaxed and sound mellow. When it comes to singing, the vocalist must be so proficient in the technicalities that the audience is not aware of them. Peggy Neville needs to work on breath control. Her deficiency in this worries the viewer. ${ }^{65}$

She summed up with: "It's all right for Close-Up and Kruschev [sic] to worry us, but not Red River Jamboree."66

Yet again Davis kept up his radio activities in addition to television. The Winnipeg Tribune featured a half-page advertisement for CKY, "The Most Listened to Station on the Prairies," on Feb. 2, 1960. It highlighted all the personalities and programs, including The CKY Ranchhouse:

Stu Davis, Canada's cowboy troubadour and well known radio and TV recording personality, serves as the Ranchhouse foreman from 4:00 to 5:00 p.m., on CKY with all

64. "Episode Guide - Red River Jamboree," TVarchive.ca, http://www.tvarchive.ca/database/18280/red river jamboree/episode guide/.

65. Jerry Lee, "Speaking of Television," Winnipeg Free Press, May 28, 1960, 31.

66. Lee, 31. 
your favorite country and western music. Stu is also heard on the Western Hit Parade every night at $9 .{ }^{67}$

Davis did numerous remotes during his time in Winnipeg, some more interesting than others. For example, during the week of February 8-13, 1960, the Hudson's Bay Company saluted the Canadian electrical industry. The event was called "The Electrifying 60's," and the attractions say much about the era:

- See an electronic range cook an egg in 20 seconds, bacon in 90 seconds

- See what happens electrically when you dial and speak on the phone

- See "Electra" - a living eel light up a bank of 24 lights

- See how Miss Canada can relax at ease and put her ironing board away ${ }^{68}$

The CKY announcers and stars broadcast, on both radio and television, all day from The Bay store on Portage Avenue. Davis went from 9 a.m. to 5 p.m. with CKY Ranchhouse. Davis also broadcast from the Winnipeg Arena throughout The Red River Exhibition in June 1960. ${ }^{69}$

For his next album, Davis compiled a number of his favourite performances from his television program. As Billboard reported in August 1960; "Stu Davis, whose newest on the Canadian London label is "Rope Around the Sun," is the feature of a new Friday night CBC network show beamed at 8:30 p.m. CST."70

By this time, Davis had accumulated modest savings from his radio and television salaries, his fees for live performances, sales of his published sheet music and recordings, and royalties from recordings by others of his songs. While not rich by any means, he purchased a ranch in Alberta, and in the world of $\mathrm{CBC}$, the timing could not have been better to move to Edmonton.

By 1960 the corporation realized that each of the Prairie provinces needed its own production centre, that Winnipeg did not represent nor could it fulfil the needs of the entire region. President Alphonse Ouimet felt Edmonton was a logical choice for the Alberta-based centre as it was the provincial capital, was undergoing an economic boom fueled by a developing petrochemical industry, and was the fastest growing part of western Canada. CBXT (Channel 5) began broadcasting on October 1, 1961 from its new building on $75^{\text {th }}$ Street. Of the 94 hours per week of content, they decided to devote $163 / 4$ hours to live local programming and 19 hours to local recorded programming. ${ }^{71}$ And they wanted Stu Davis.

67. Winnipeg Tribune, February 2, 1960, 4.

68. "The Bay Salutes the Phenomenal Progress of the Canadian Electrical Industry," Winnipeg Tribune, February 6, 1960, 20.

69. "See You at the Ex," Winnipeg Tribune, July 1, 1960, 8.

70. Bill Sachs, "Folk Talent \& Tunes," Billboard, August 15, 1960, 33.

71. "CBXT-DT," History of Canadian Broadcasting, Canadian Communications Foundation, http://www.broadcasting-history.ca/listing and histories/television/cbxt-dt. 
Ann Henry, the columnist who covered radio and television for the Winnipeg Tribune, entitled her June 7, 1961 column "Friendly Stu Davis Moving to Edmonton":

Stu Davis is withdrawing from the Red River Jamboree show, and will move west to Edmonton to do the first network show from the new CBC studio when it opens in the fall. The move fits in with his plans to move closer to some of his business interests in Alberta, one of which is the cattle business. Stu feels that when he is "all washed up as an entertainer" - his own words - Alberta is the place he and his family would like to retire to...Stu's last show, video-taped, will be seen here June $24^{\text {th }}$. Then a cowboy singer named Stu Phillips, from Calgary, comes to Winnipeg to take over... ${ }^{72}$

She continues:

Stu Davis, an unassuming, friendly, very nice person, is, in my opinion easily the best of the cowboy singer-entertainers, and that includes them all, even old Ern. He was free of all those asinine little moonings that characterize most western balladeers. He has a good voice and he never took himself too seriously, one of the secrets of his success. He'll be missed on Red River Jamboree. ${ }^{73}$

Davis recalled: "In 1961 I decided it was time to get that ranch I'd been hoping and working towards and returned to Edmonton where I joined the CBC when it opened its television studios." ${ }^{74}$ The 960 -acre ranch, called the Lazy S-D, was located near Hoadly, approximately eighty miles southwest of Edmonton. Davis started to raise Hereford and Angus cattle. As when he was young, he and his family spent the summers on the ranch, and during the school year they lived in the Ottewell subdivision at 9259-74 Street.

Davis re-booted his Winnipeg-era program Rope Around the Sun for several more seasons, and in 1963 also brought back his Saturday evening The Stu Davis Show. Like the original Winnipeg show, this also featured Davis telling one long story per episode ("The Tornado," "Tail of the Dog," "My First Bronc Ride," "The Indian Horse Race," "Old Wheezer Earned His Biscuits," "The Pigeon Who Saved the Day," "The Bacon Loving Bear") interspersed with a combination of cover songs and originals. ${ }^{75}$

Davis also had to recruit a new backup band. First he reunited with bassist Wally McDonald who had been in the Radio Wranglers twelve years earlier. McDonald had followed a somewhat similar path to Davis. He was an alumnus of The Sons of the West, which featured fiddler "King" Ganum and singer Omar Blondahl. The Sons were the house band of CBC Radio's Alberta Ranch House throughout the 1950s. McDonald had also played with Jimmy Wakely, American country singer and radio host, who had a minor hit song "Skip Along." The other musician was fiddler Alfie Myhre. Myhre had established his

72. Ann Henry, "Friendly Stu Davis Moving to Edmonton," Winnipeg Tribune, June 7, 1961, 12.

73. Henry, 12

74. "The CBC's Stu Davis," Edmontonian, April 1964, 5.

75. "Episode Guide - The Stu Davis Show," TVarchive.ca, http://www.tvarchive.ca/database/18624/stu davis show, the/episode guide/. 
credentials as a member of Jimmy Arthur Ordge \& The Silver Valley Boys, then as part of Wilf Carter's backup band during his 1957 tour of Canada, and most recently as a member of Gaby Haas's Barn Dance Show. The three of them, plus Duane Davis, were to become The Pathfinders, a versatile and professional studio band.

Together they recorded the album Stu Davis Salutes the Western Stars, which came out in March 1961 on London Records in Canada and on Richmond Records in the US. Billboard did not stop the presses with excitement; their reviewer put it in the "Moderate Sales Potential" column and wrote: "Stu Davis pays tribute to a group of famous country and western artists by singing the tunes they made famous.... Interesting set that could interest some fans." 76

Although he was not a spotlight hog, Davis knew the ongoing value of publicity. And he worried that he was not getting much from CBC in Edmonton. On January 13, 1964 he penned a letter to Dennis O'Neill at $\mathrm{CBC}$ in Winnipeg:

How is everything back in Winnipeg? Hope all is well with you and yours as we start this brand New Year. Denis, I've been after my various producers here every [sic] since coming to Edmonton to keep you posted on my various activities - just to get a "mention" now and then in the "Times" and other papers you submit information to...but to no avail. I haven't had a single write-up or a mention since I left Winnipeg and many of my fans are still in doubt as to my whereabouts. ${ }^{77}$

He continues:

So, I decided to take the bull by the tail - so to speak - and drop you a note to see if you would remedy the situation. First of all, I would like something mentioned that was never mentioned before and that is the fact that I resigned as host of Red River Jamboree to move to Edmonton for two reasons. First to do my "Stu Davis Show" from the new CBC station - and second - to be closer to my ranching activities. I have a 960 acre cattle ranch - situated in central Alberta on the Blindman River. Presently I have 60 head of Hereford cattle - and two quarter-horses named "SUNDANCE" and "KENO." Most of my spare time is spent there - but I still find time to keep up with my songwriting, making records, and writing material for my weekly CBC Television show. I have just had my tenth long-play album released by London Records - and the $11^{\text {th }}$ is in the making. These are top sellers in Canada according to Mr. Fraser Jamieson - manager of London Records and they are also selling very well in the States too. One of my LP albums was accepted by Her Majesty - Queen Elizabeth and she acknowledged receipt of it with an official letter. Will Hoskins - an English song-writer composed one of the

76. "C\&W LP's", Billboard, March 20, 1961, 31.

77. Stu Davis to Dennis O'Neill, January 13, 1964, p. 1,"Biography Files - Davis, Stu," U-15-2-18 file 89, CBC Manitoba Communications Department General Records, Archives of Manitoba. 
songs included in the album and he sent the record to the Queen. Another was accepted by the Queen Mother...... ${ }^{78}$

He finished with:

These are just a few points that you may make use of Denis...I certainly hope you can....because I know from the letters I receive, a lot of my fans have lost track of me... and this will never do. ${ }^{79}$

He added a P.S.: "I think you'll admit that three years without any publicity is a "mighty long time"!! It worked: a profile and portrait of Davis was included in the next issue (Feb. 8-14, 1964) of CBC Times. ${ }^{80}$ It started: "Where's Stu Davis?"

Davis received another big nod of recognition when he guest-starred on the $\mathrm{CBC}$ television special The Hank Snow TV Spectacular in November 1965. This was supposed to be Snow's "re-introduction" to his Canadian homeland, and the network put considerable planning and funds into making it a special night. The production earned favourable reviews. One by critic Brian Chalker in RPM:

CBC's Show of the Week presentation...must surely have been the finest country music television production to be seen in many a year. The harsh criticism aimed at current CBC country music policies, in a recent issue of RPM, must therefore be partially relinquished...it would appear that deep down in the dungeons of $C B C$, there are writers and producers who are capable of creating a fast moving intelligent country and western show.

Nova Scotia born Hank Snow, together with The Rainbow Ranch Boys, Stu Davis, Cousin Clem (Gordie Tapp), Charlie Chamberlain and Johnny Mooring presented country music fans with fifty minutes of sparkling down to earth entertainment. ${ }^{81}$

Chalker ran through the offerings of each. Snow sang his greatest hits: “I'm Movin' On," "I've Been Everywhere," "The Golden Rocket," and "Music Makin' Mama." Then:

Stu Davis gave viewers a taste of the 'western' side of country music with his versions of 'Cimmaron' and 'What a Fool I Was', whilst Charlie Chamberlain and Cousin Clem presented their tongue-in-cheek 'Freight Train Blues' and a brief dance, shuffle routine..$^{82}$

78. Stu Davis to Dennis O'Neill, 1-2.

79. Stu Davis to Dennis O'Neill, 2.

80. "Around CBC." CBC Times, February 8-14, 1964.

81. Brian Chalker, "The Hank Snow TV Spectacular 'Show of the Week'," RPM, November 22, 1965, 7.

82. Chalker, 7. 
The review finished with:

After the recent Tommy Hunter A-Go-Go Show it was a welcome relief to see the dancers well in the background. You see, it can be done, can't it? The emphasis was on country music - and country music we sure did get - congratulations $C B C$, for a splendid show. ${ }^{83}$

Davis returned the following year with another program. On April 2, 1966 the Winnipeg Tribune, feeling they still owned a piece of him, featured an article "Our Stu Returns":

Canada's popular cowboy Troubadour, Stu Davis of Winnipeg, is the singing host of a new 15-minute program of western cowboy ballads and traditional folk music, to be seen on Channel 6 Saturday evenings at 6:30 beginning April 2. Featured on each show with Stu is his son Duane, a 20 year old singer-guitarist, and an instrumental group called The Pathfinders. On the first Stu David [sic] Show, he sings Streets of Laredo, then teams up with Duane on Homesteaders Lament and I'm Going to Change Everything. Duane sings a French folk song, Sleep My Love. ${ }^{84}$

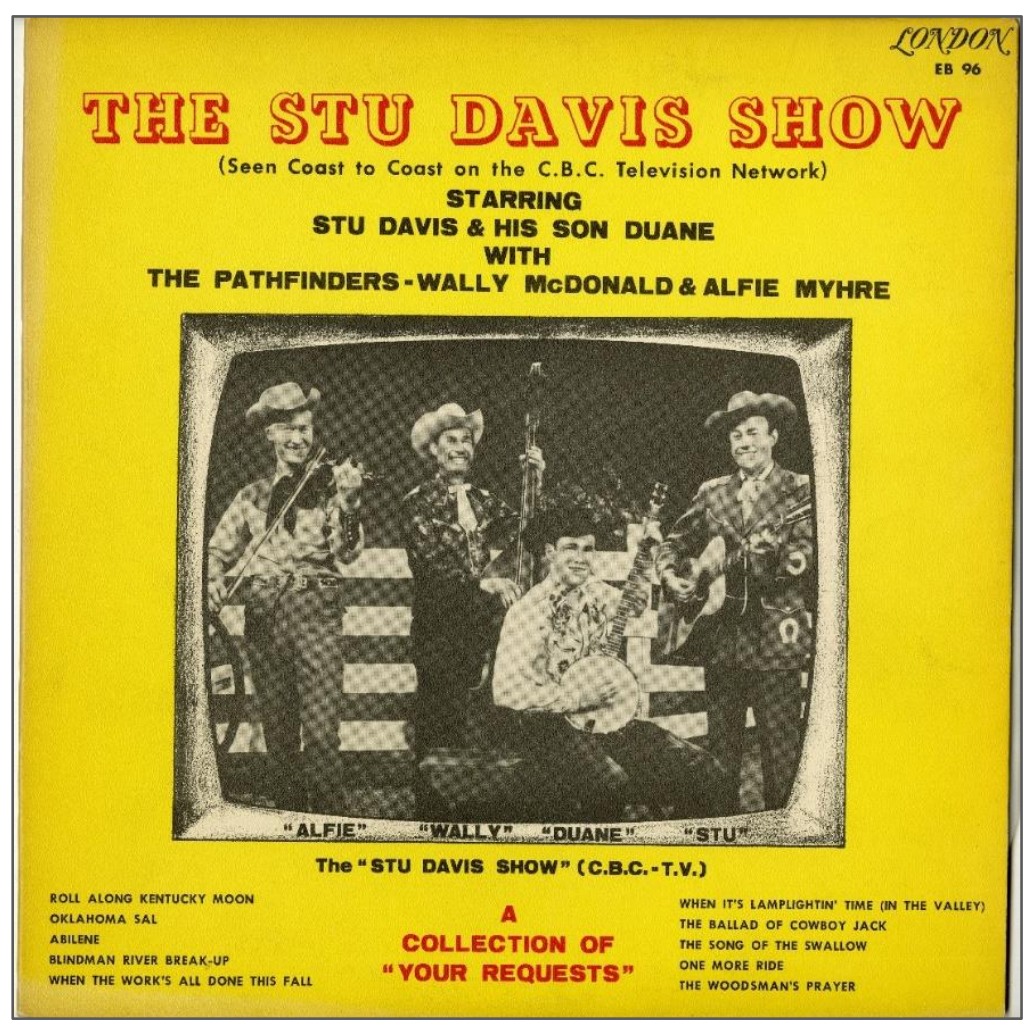

Cover of The Stu Davis Show: A Collection of Your Requests (The Pathfinders: I. to r. Alfie Myre, Wally MacDonald, Duane Davis, Stu Davis) (London Records, LP) 1966
In late 1966 Davis, following his earlier example with Rope Around the Sun, compiled 10 of the most popular, most requested performances from the television show, and put out another album simply called The Stu Davis Show.

Davis decided to take greater control of his activities, and put them on a more business-like footing. Accordingly he incorporated himself as Stu Davis Enterprises Ltd. on December 16, 1965. The directors and original shareholders were Davis and his wife Evelyn. Then sons Duane and Derry were assigned shares. The company started with authorized capital of $\$ 200,000$. According to the Memorandum of Association, the objectives of the corporation were:

83. Chalker, "The Hank Snow TV Spectacular," 7.

84. "Our Stu Returns," Winnipeg Tribune, April 2, 1966, 48. 
a) To carry on the business of producers of radio and television programs

b) To act as principal or agent in the furnishing of all types of musical and variety programs, and in all methods of reproducing voice or music for the entertainment of the public at large; without restricting the generality of the foregoing, to assemble and supply for entertainment an orchestra, singers, dancers, for the furnishing of programs devoted to classical music, western music and songs, folk music and songs, and all types of dancing and music

c) To act as publishers and recording specialists for the publication and distribution of music and song; to acquire by purchase, lease, royalty agreement or in any other manner the sole right to songs and music

d) To acquire by purchase, lease, option or otherwise all such lands and premises and all types of machinery, equipment and installations required in the production of music, songs, television or radio productions

h) To enter into contracts with publishers, agents, owners of radio and television networks, and all other persons or bodies corporate in the business of supplying all types of music and songs for the entertainment of the public at large..$^{85}$

He then brought into the company his other interests:

To carry on the business of farming and ranching; without restricting the generality of the foregoing to purchase and operate land, buildings and livestock required to carry on farming operations, and to act as principal or agent in the marketing and sale of all types of farm produce, and animals raised for market purpose ${ }^{86}$

All of Davis's interests and talents, music, storytelling, broadcasting, and love for Canadian history, came together in Canada's Centennial year. His first project was a new album, The Stu Davis Centennial Album. He was backed by Wally McDonald, Alfie Myhre, and by both his sons, Duane and Derry. George Payne, announcer friend from the CJCA days, did a brief spoken word introduction.

As per the jacket notes:

In this special LONDON CENTENNIAL ALBUM - one of Canada's favourite sons - STU DAVIS - offers a salute in song to each and every province from the Atlantic to the Pacific, with eleven original Canadian folk songs. STU DAVIS is a "Genuine" Canadian in every sense of the word, having been born on DOMINION DAY - July $1^{\text {st }}$. Though plagued by numerous offers to move to the U.S. Stu elected to pursue his career in his Native

85. “Memorandum of Association of Stu Davis Enterprises Ltd.," Stu Davis Enterprises Corporate File \#40394, 12.

86. “Memorandum of Association," 2. 
land and in so doing, has contributed greatly to the entertainment of his fellow Canadians for over 25 years. ...Join STU DAVIS and his musical tribute to Canada's $100^{\text {th }}$ birthday. We are certain you will enjoy it. ${ }^{87}$

His second project was hosting a 13-week mini-series aired on CBC during November and December 1967. Helping him achieve his vision was producer and director Jack Emack as well as a camera crew and sound engineer. It was an expensive undertaking, as the group travelled more than sixty-four thousand

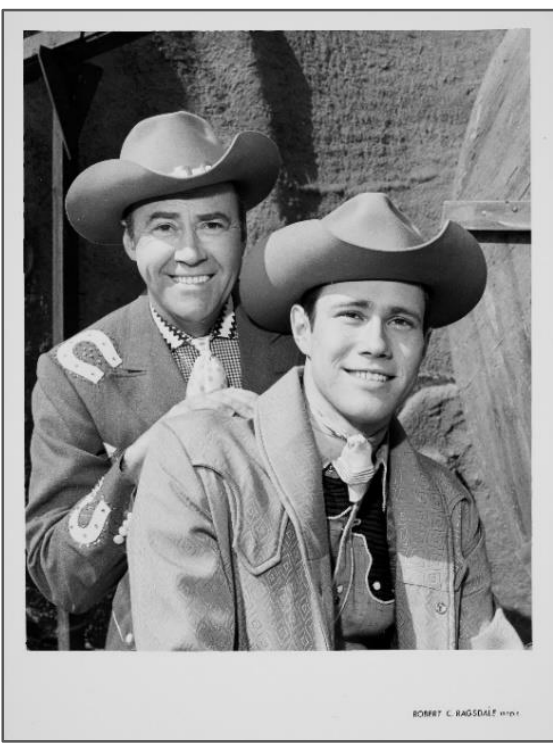

Stu and Duane Davis, promo shot for television series Trail Riding Troubadour, 1967

Photo by Robert Ragsdale

CBC Still Photo Collection kilometers, from April to June, visiting various historic sites in each of the Prairie provinces. The Edmonton Journal introduced the program on October 27:

Trail-Riding Troubadour, a special centennial series produced by CBC Edmonton, uses both documentary and variety techniques in re-telling the saga of the Canadian West...Canada's "cowboy troubadour", Stu Davis, and his balladeer son, Duane, narrate the history of the early West, with the added dimension of the songs and ballads that grew out of it. They tell of the Indian and the buffalo and their losing battle against the influx of settlers, miners and early businessmen who fought successfully to tame the wilderness. ${ }^{88}$

The article goes into some detail:

The series of half hour color programs was shot entirely on location at historical sites across the three prairie provinces. In Alberta, the program visits locations such as Elk Island Park, where some of the few remaining herds of the original millions of prairie buffalo still survive, the Crowsnest coal-mining towns Hillcrest and Frank, where men fought disease and disaster only to have the discovery of oil make their industry obsolete, and the Gattey Ranch where the combination of cowhand and cutting horse survives amid modern agricultural conveniences.

In Saskatchewan Trail Riding Troubadour visits Fort Battleford and Batoche - hot spots of the Riel Rebellion of 1885, and joins an authentic wagon train for a three-day trip between Gravelbourg and Wood Mountain. Manitoba's rich historical heritage forms an important part of the series. Included in the Manitoba segments are the original Selkirk Settlement in the Red River Valley north of Winnipeg, Lower Fort Gary [sic], the point of embarkation for settlers, traders and explorers travelling across the vast expanses of

87. The Stu Davis Centennial Album, London Records EB. 107, 1967, jacket notes.

88. "Saga of Canadian West Retold - With Its Songs," Edmonton Journal, October 27, 1967, 12. 
prairie and parkland to the mountains; and the Icelandic settlements around Gimli, where hardy immigrants of Viking extraction came to fish, farm, and add their particular color to the Canadian ethnic mosaic. ${ }^{89}$

The series, recut as a single production, was entered in film festivals in Europe and shopped to US broadcasters.

The Stu Davis Show experienced a second life in 1968. A New York-based distributor by the name of TapeNet, a subsidiary of Krantz Films Inc., licensed a range of Canadian television programs to place into the American and international broadcasting schedules. Krantz negotiated with CBC, CTV, and CFTO for the syndication rights to first-run shows for a maximum of twenty hours per week. ${ }^{90}$ Some of the programs included Festival (twelve 90-minute drama and comedy specials); Wayne \& Shuster (four 1hour specials), Sports Hot Seat (fifty-two 1-hour interview shows), Perry's Probe (260 30-minute shows with Norm Perry), Wojeck (the coroner drama starring John Vernon), The Tommy Hunter Show (thirtynine 30-minute programs), and The Stu Davis Show (thirty-nine 30-minute programs). They were showcased at the National Association of Broadcasters conference in Chicago in April of that year.

In April 1968, with youngest son Derry out of school and out on his own, Davis bought another smaller ranch on R.R. \#1 near Ardrossen, thirty kilometres east of Edmonton on Highway 16. He and his wife moved there, and it became the new head office of Stu Davis Enterprises Inc.

It appears that Davis's passion for music and his natural musical skills were imparted to his two sons. An article from 1969 stressed the family tradition:

Both Stu's sons, Duane and Derry, are involved in the music world - both are featured regularly on TV on "The Stu Davis Show" - and at the moment the boys are heard each week on the CBC radio network on "The Duane Davis Show". Duane sings a mixture of country-western, folk and folk-rock, and also plays classical guitar and five-string banjo. Derry started in the rock and roll field, but has broadened into blues, jazz and countrywestern. His trio are the accompanists for brother Duane on his program...Derry is just 18 but is fast gaining recognition as one of the country's top guitarists. ${ }^{91}$

Duane seemed to be constantly at his father's side throughout much of the 1960s, and was featured prominently on The Stu Davis Show and on Trail Riding Troubadour. Upon going out on his own, he showed his folk connections immediately. In 1969, he put out Reflections, his first solo album, which was replete with covers of Jimmy Webb, Bob Dylan, and Buffy Sainte-Marie tunes. It was recorded with producer Tommy Banks in Century II Studios and issued jointly by CBC and Capitol Records Canada.

89. "Saga of Canadian West Retold," 12.

90. "Distributor Plan to Sell Canadian Programs in U.S.," Edmonton Journal, March 8, 1968, 30.

91. Brian Wills, “...Meanwhile, Back at the Lazy SD...," Canadian Composer, no. 42 (September 1969): 8. 
Derry followed a different path. As an integral member of the 1960s Edmonton bands King Beezz and Warp Factor, and then the Saskatoon-based Witness Inc., he moved squarely into the field of electric rock. He also developed as a talented songwriter and was courted by Brian Chater's Summerlea/Winterlea Music in Toronto in 1969.

Toward the end of that year, the respected journal Canadian Composer featured a lengthy, thoughtful article on Davis. Written by Brian Wills, it was not the shallow promo piece Davis had been used to for most of his career. It ran through his history, but portrayed him as a three-dimensional person. It took him seriously as a composer, a singer, and an on-air personality. It discussed his life outside of music, his quiet but firm belief in family values, mentioned his other creative pursuits such as painting, and his business interests pertaining to the ranch and real estate. But it also hinted that Davis was aware his approach was losing its currency:

In 1969 Davis is a contented man. Still writing a song a week, involved with television specials and recording... he recognizes that the "old west" is gone forever....A lot of the songs he has written have certainly been about a "real way of life" and still are: but of course just like the vanishing way of life of the cowboy, the songs and ballads of the true cowboy of old are vanishing too. ${ }^{92}$

Davis was perceptive enough to realize that the worlds of both musical performance and broadcasting had also moved on, had undergone a fundamental change in attitude, and that he was not about to change. While his fans would remain loyal to him, he knew that radio and television wanted younger, more hip music and on-air personalities. As he was also feeling more comfortable on the ranch, and less so in front of the camera, he decided to call it a day.

In 1970 he gathered together another selection of songs from his television series, along with a few old and new tunes, and released an album entitled The Songs and Music of Stu Davis, Trail Riding Troubadour on Dominion Records, the label of the Toronto-based Canadian Music Sales. It was reviewed in $R P M$ :

Impressive country lineup of backup musicians: Stu Davis, rhythm guitar; Derry Davis, electric lead and drums; Duane Davis, lead acoustic and banjo; Alf Myhre, violin and mandolin; and Wally McDonald, string bass - should attract the "earthy" listener. ${ }^{93}$

Davis put out his final album in 1971. It was entitled Songs from the Heart of Johnny Canuck. Though the music was still country-ish (it included several re-recordings of earlier songs such as "In Daddy's Footsteps"), Davis left his cowboy hat, shirt and boots in the closet. On the album's cover he was photographed wearing a tweed hat and his normal "civilian" clothes. It likely puzzled his fans, and his final label, Birchmount Records, declined to issue a follow-up album.

92. Wills, “...Meanwhile, Back at the Lazy SD...," 8.

93. "Songs and Music of Stu Davis - Trail Ridin' Troubadour," RPM, July 24, 1971, 18. 
By 1975, Davis had moved from his Ardrossen home to Calgary. With neither a recording nor a media career nor a ranch, Stu Davis Enterprises became superfluous. In May 1978, it was struck from the Alberta Corporate Registry. ${ }^{94}$

Somewhat unexpectedly Davis had established a small but dedicated fan base in Germany, no doubt due to his being broadcast over the Armed Forces Radio Service in the post-war period. There was one label in particular that wanted to preserve and make available again the "real" country and western music of the 1940s and 50s. This was Cattle Records, run by Reimer Binge in Sulzheim. Starting in 1971, Cattle reissued early (and long out of print) material by such artists as Rosalie Allen, Bob Wills, Patsy Montana, Cowboy Sam Nichols and his Rangesters, Tex Banes \& The Hayseeds, Sons of the Pioneers, Carl Story \& His Rambling Mountaineers, and from Canada, Smilin' Johnnie and His Prairie Pals. ${ }^{95}$ Each one was carefully curated, and included voluminous and well-researched jacket notes. In 1987 Cattle Records put out a compilation LP Let's Go Back to the Country with Canada's Cowboy Troubadour. The eighteen songs included Davis's 78s releases from his Sonora, RCA, and Aragon periods, none of which were then available.

The second major written profile was a cover story written by historian Dan Foster for Country Music News in January 1990. It also took a run through Davis's life and career in some detail, touching on all his songwriting and recording successes. Foster subtly incorporated a quiet request for a reevaluation of Davis's impact on Canadian country music when he wrote, "...yet he remains one of the real pioneers of the industry, who awaits recognition from that same industry." 96 The hint was received loud and clear, and in October 1993, Davis was finally inducted into the Canadian Country Music Hall of Fame alongside Stu Phillips, Ward Allen, Dick Damron, Carroll Baker, and Stompin' Tom Connors. ${ }^{97}$

Davis passed away in 2007 at the age of eighty-six. Over the span of his three decades in the limelight, Davis helped to bring country \& western music from the twangy, backward, rural and simplistic, to the smooth, family-friendly and even semi-urban. His ease before both live audiences and the television camera, and his warm, relaxed delivery, earned Davis the nickname of "The Sagebrush Como," but it also belied his incredible work ethic. He did not just sing the hurtin' songs from the worlds of cattle and heartache, he brought back the storytelling aspect to much of his work, a touch of good-natured humour, and the view that despite all its problems, maybe the world (especially Western Canada) was a good place to be. He brought a touch of class, even respectability, to country music. He made it acceptable to listen to $c \& w$ without being considered a "hick." As if that were not enough, he also did more to bring country \& western music into the mainstream world of Canadian broadcasting-both radio and television - than any other Canadian artist of his time.

94. H. Thomas (Registrar of Companies), "Companies Struck Off the Registry," May 31, 1978, Stu Davis Enterprises Corporate File \#40394.

95. "Cattle Records," Discogs, https://www.discogs.com/label/121607-Cattle-Records.

96. Dan Foster, "The Stu Davis Story...Pioneer of Canadian Country Radio and TV," Country Music News, January 1990, 23.

97. “Inductees Named for Country's Hall of Fame,” RPM, October 16, 1993, 15. 


\section{Sources}

“Around CBC." CBC Times, February 8-14, 1964.

"The Bay Salutes the Phenomenal Progress of the Canadian Electrical Industry." Winnipeg Tribune, February 6, 1960, 20.

Billboard (various issues)

Binge, Reimer. Let's Go Back to the Country with Canada's Cowboy Troubadour Stu Davis. Cattle Records LP 112, 1987, jacket notes.

Brylawski, Samuel. "Armed Forces Radio Service: The Invisible Highway Abroad." Quarterly Journal of the Library of Congress 37, no. 3/4 (1980), 441-57.

“Canada's Cowboy Troubadour." CBC Times - For the Prairies, May 26-June 1, 1957, 1.

“Canada's Cowboy Troubadour." Leather Craftsman, May-June 1960, 29.

“Canada's Cowboy Troubadour, Stu Davis, Dies at 85." Hillbilly-Music.com. http://www.hillbillymusic.com/news/story/index.php?id=7015.

“Canadian C\&W Series.” Variety, August 9, 1967, 35.

“The CBC's Stu Davis." Edmontonian, April 1964.

Chalker, Brian. "The Hank Snow TV Spectacular 'Show of the Week'." RPM, November 22, 1965.

Davis, Stu. "My Most Successful Work." Canadian Composer, no. 34 (November 1968).

Davis, Stu. Songs by Stu Davis, Folio No. 3 (Toronto: Canadian Music Sales, 1953).

Davis, Stu. Stu Davis Radio and T.V. Song Book. Toronto, ON: Gordon V. Thompson, 1957.

Davis, Stu. Stu Davis' Saddle Bag of Songs, Folio No. 2 (New Westminster: Empire Music Publishers, 1949).

Davis, Stu. Stu Davis' Song Corral, Folio No. 1 (Toronto: Gordon V. Thompson, 1948).

“Distributor Plan to Sell Canadian Programs in U.S." Edmonton Journal, March 8, 1968.

"Episode Guide - Holiday Ranch." TVarchive.ca. http://www.tvarchive.ca/database/17268/holiday ranch/episode guide/. 
"Episode Guide - Red River Jamboree." TVarchive.ca.

http://www.tvarchive.ca/database/18280/red river jamboree/episode guide/.

"Episode Guide - The Stu Davis Show." TVarchive.ca. http://www.tvarchive.ca/database/18624/stu davis show, the/episode guide/.

Foster, Dan. "The Stu Davis Story...Pioneer of Canadian Country Radio and TV." Country Music News, January 1990.

Gilbert, George. "When Hub Goes for Hillbilly Airs Bet They're In!” Variety, January 8, 1947.

"Gives Cheap B Westerns of the 40s a Bad Name." IMDb. February 2001. https://www.imdb.com/title/tt0040654/reviews.

“Inductees Named for Country's Hall of Fame." RPM, October 16, 1993, 15.

Lee, Jerry. "Speaking of Television." Winnipeg Free Press, May 28, 1960.

Lepkin, Marion. "Lively Partners; No Rumpus.” Winnipeg Free Press, July 6, 1957.

Mackie, John. "Music Man Has Found Harmony in Life: Al Reusch, a Man of Many Parts in Western Canadian Music, Has Been Performer, Disc Jockey and Producer." Vancouver Sun, December 19, 1998, B1.

Murray, Tom. "Canadian Country Legend Kept Close to Home: Tribute Planned to Honour Songwriter Stu Davis." Edmonton Journal, April 9, 2010, D7.

“Network Radio in Can. - Real Live." Variety, July 20, 1960, 40.

“New 'Stu' on Jamboree Menu." Winnipeg Free Press, June 3, 1961.

“Northwest Stampede," Monthly Film Bulletin 17, no. 193 (January 1, 1950): 30.

"On the Cover." CBC Times - Eastern Edition, July 25-31, 1959, 2.

"Our Cover: Swing Your Partner." CBC Times, Sept. 29-Oct. 5, 1957, 8.

"Red River Jamboree." TVarchive.ca. http://www.tvarchive.ca/database/18280/red river jamboree/details/.

Roy, Fred. "Canada Salutes Nashville - Music World Special." Music World, November 1957.

Roy, Fred. "Reviews and Ratings of the Latest Country \& Western Releases." Music World, July 15, 1957.

Roy, Fred. "Round-Up Time with Fred Roy." Music World, July 15, 1957. 
"Saga of Canadian West Retold - With Its Songs." Edmonton Journal, October 27, 1967.

Schmalz, Wayne. On Air: Radio in Saskatchewan. Regina, SK: Coteau Books, 1990.

"Something for Everyone at 980 on Your Dial." Regina Leader Post, May 22, 1948.

"Songs and Music of Stu Davis - Trail Ridin' Troubadour" (review). RPM, July 24, 1971.

Spragg, Dennis. "The Armed Forces Radio Service." Glenn Miller Archive, University of Colorado Boulder. https://www.colorado.edu/amrc/sites/default/files/attached-files/THE ARMED FORCES RADIO SERVICE 0.pdf.

“Stu Davis." CBC Times (Prairie Region), August 2-8, 1953.

"Stu Davis Back in Song Series." Winnipeg Free Press, April 2, 1966, Leisure TV and Radio Section, 2.

"Stu Davis: May All the Trails You Travel Lead to Happiness." http://studavis.blogspot.com.

“Thar's Mother Lode in Twangy Music Strains." Variety, January 8, 1947, 219.

Vipond, Mary. Listening In: The First Decade of Canadian Broadcasting, 1922-1932. Montreal, QC: McGill-Queens University Press, 1992.

Wills, Brian. “...Meanwhile, Back at the Lazy SD...” Canadian Composer, no. 42 (September 1969): 8.

\section{Discography}

\section{SINGLES}

78 rpm - Sonora Records (H 7021)

"Rainbow at Midnight" /"The Bottom Fell Out of the Sky"

Released: November 1946

78 rpm - Sonora Records (H 7024)

"I Tipped My Hat and Slowly Rode Away"/"I Can Beat You Doin' (What You're Doin' to Me)" Released: December 1946

78 rpm - Sonora Records (H 7027)

"Land, Sky and Water"/"Darlin', Now I Know the Reason Why"

Released: 1947 
78 rpm - Sonora Records (H 7029)

"What a Fool I Was" / Crossroads"

Released: March 1947

78 rpm - RCA Victor Records (20-2750)

"When the Snowbirds Cross the Rockies" /"Welcome Back to My Heart"

Released: March 1948

78 rpm - RCA Victor Records (20-2909)

"Too Far Apart" / Sweetheart of Yesterday"

Released: June 1948

78 rpm - RCA Victor Records (20-3054)

"Crying for You" /"The Dude in the Ten Gallon Hat"

Released: August 1948

78 rpm - RCA Victor Records (20-3212)

"Always Keep Your Promise"/“I'm Gonna Leave Town"

Released: November 1948

78 rpm - Aragon Records (AR-177)

"Canadian Waltz"/“Child of Divorce"

Released: 1950

78 rpm - Rondo Records (R-252)

"I Can Beat You Doin' (What You're Doin to Me)"/"Land, Sky and Water"

Released: 1951

78 rpm - Aragon Records (AR-203)

"I Looked for Love" /"In Daddy's Footsteps"

Released: 1952

78 rpm - Aragon Records (AR-207)

"Deserted" /"Black Mountain Rag"

Released: 1952

Note: credited to Fiddlin' Red Crawford with Stu Davis and his Melody Mavericks

78 rpm - Aragon Records (AR-210)

"Fate of the Flying Enterprise"/"Phantom Waltz"

Released: 1952 
78 rpm - Aragon Records (AR-224)

"I Went to Your Wedding" /"Why Should I Send You Flowers?"

Released: 1952

78 rpm \& 45 rpm - Apex Records (26381)

"The Legend of the Jeebi"/"Parking Meter Blues"

Released: 1952

45 rpm - Apex Records (26386)

"I'm Gonna Foreclose the Mortgage"/"Three Little Secrets"

Released: 1952

45 rpm - Apex Records (26393)

"Queen Elizabeth Special" / Foothills Breakdown"

Released: 1952

45 rpm - Apex Records (26396)

"Oil Capital Shuffle"/"Red Crawford's Breakdown"

Released: 1952

Note: credited to Red Crawford, Stu Davis \& The Cowtowners

45 rpm - Apex Records (26399)

"She's Cute as a Bug in a Rug"/ "Lovelorn Heart"

Released: [1953]

45 rpm - London Records (306)

"Wild Weeds"/"Honky Tonk Serenade"

Released: [1957]

45 rpm - London Records (307)

"Dear Mr. Disc Jockey" /“I'd Be Glad to Forget You"

Released: 1957

45 rpm - London Records (M.17080)

"Broken Love"/"Queen of Twilight"

Released: [1959]

45 rpm - London Records (M.17320)

"Get Away Old Man, Get Away" /"Girl That I Marry"

Released: [1960] 


\section{ALBUMS}

Stu Davis Invites You to Saddle Your Worries to a Song - London Records (EB. 2)

"They're Burnin' Down the House I Was Brung Up In"; "The Cowboy's Prayer"; "The Little Shirt My Mother Made for Me"; "Shepherd of Mine"; "Diggin' with a Hoe"; "I Still Do"; "Take Me Back to My Boots and Saddle"; "I Took It"; "Carrier Pigeon"; "The Piggy Back Song"

Released: 1956

Rope Around the Sun with Stu Davis - London Records (EB. 4)

"Honey, Baby Mine"; "The Hangin' Tree"; "Fort Worth Jail"; "What a Fool Was I"; "The Gangster's Warning"; "The Rose Upon the Bible"; "Swaller-Tailed Coat"; "Ripple Rock"; "Dark as a Dungeon"; "New Broom Boogie"

Released: June 1959

Stu Davis Salutes the Western Stars - London Records (EB. 6 - also on Richmond 20090)

"Let's Say Goodbye (Like We Said Hello)"; "Lilli Marlene"; "I’m Going Back to Whur I Come from";

"Wedding Bells"; "There's a Star-Spangled Banner (Waving Somewhere)"; "Mother, the Queen of My Heart"; "You Are My Sunshine"; "Cool Water"; "You're the Only Star in My Blue Heaven"; "Mommy, Please Stay Home with Me"

Released: February-March 1961

The Touch of God's Hand with Stu Davis - London Records (EB. 9)

"Country Church"; "He's the Lily of the Valley"; "Gentle Hands; From the Manger to the Cross"; "The Touch of God's Hand"; "A House Built on a Rock"; "Singing an Old Hymn"; "Walls of White"; "Just Like Me"; "Hold Fast to the Right" Released: April 1, 1960

Note: credited to Stu and Fred The Harmony Boys

A Collection of Country-Western Classics - London Records (EB. 26)

"Driftwood on the River"; "Paddle Your Own Canoe"; "Blue Guitar"; "Né-Hah-Nee"; "Dust"; "It Takes a Heap of Dreamin' (To Dream Your Blues Away)"; "The Kentuckian Song"; "Rockin' Alone (In an Old Rockin' Chair)"; "Waltz of the Roses"; "Legend of the White Buffalo"

Released: [1960]

Note: "featuring Stu and Fred The Harmony Boys, Jimmie Pirie on the electric, Spanish \& steel guitar"

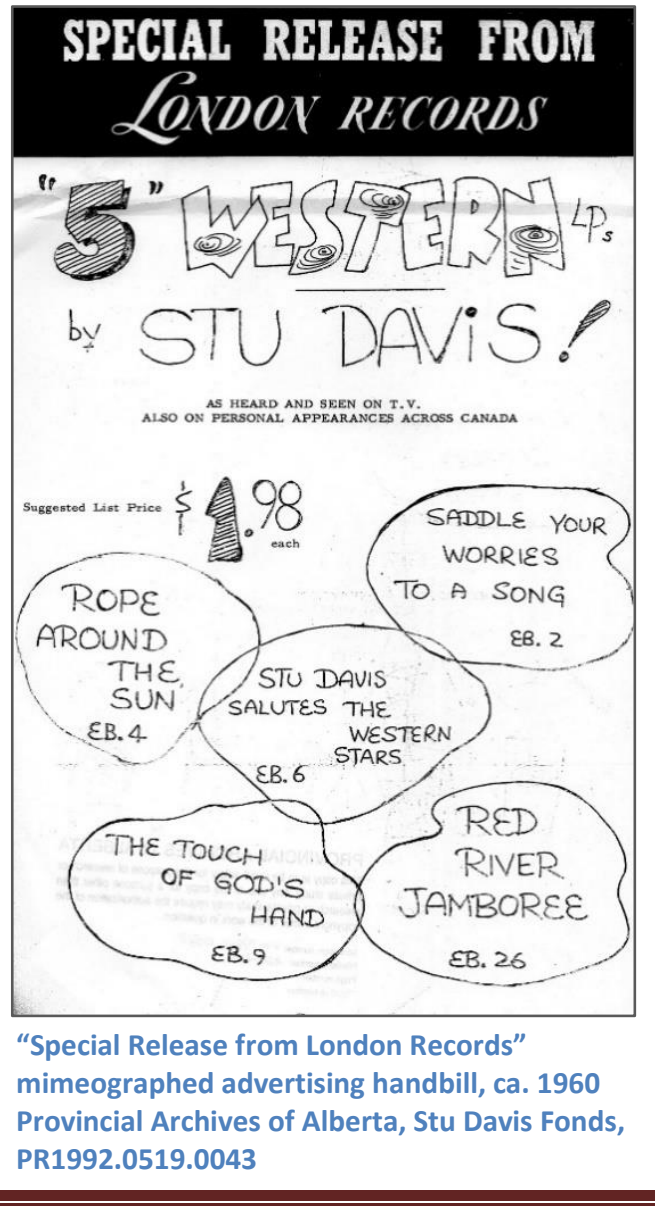


Red River Jamboree - London Records (EB. 26 - above LP re-issued with new title)

"Driftwood on the River"; "Paddle Your Own Canoe"; "Blue Guitar"; "Né-Hah-Nee"; "Dust"; "It Takes a Heap of Dreamin' (To Dream Your Blues Away)"; "The Kentuckian Song"; "Rockin' Alone (In an Old Rockin' Chair)"; "Waltz of the Roses"; "Legend of the White Buffalo"

Released: [1961]

Note: "featuring Jimmie Pirie on the electric, Spanish \& steel guitar"

Stu Davis Salutes the Western Stars Volume 2 - London Records (EB. 33)

"At Mail Call Today"; "Four Walls"; "Cry of the Wild Goose"; "In Daddy's Footsteps"; "When It's Springtime in Alaska"; "Brave Man"; "What a Fool I Was"; "Country Boy"; "May You Never Be Alone"; "I've Got a Woman's Love"

Released: 1960

Stu Davis Presents Jimmie Pirie's Guitar-Ama - London Records (EB. 35)

"I Love You"; "Aurora"; "Black Is the Color"; "Schon Rosmarin"; "I Wish You Love"; "Wheels"; "Estrellita"; "Beyond the Reef"; "Adelita"; "Red Sails in the Sunset"

Released: [1961]

Boothill Ballads and Songs of the Cowboy Troubadour - London Records (EB. 39)

"Six Notches"; "Bury Me Not on the Lone Prairie (The Song of the Dying Cowboy)"; "The Ballad of Curly Joe"; "He's Gone Up the Trail"; "Ride Clear of This Town"; "The Streets of Laredo"; "No More I Want to Roam Again"; "Rusty Spurs"; "The Chase"; "Five Bullets in My Old Six-Shooter"

Released: 1961

Just Plain Folks - London Records (EB. 49)

"Gold Diggers"; "When I'm Gone You'll Soon Forget"; "Little Crushed Rose"; "Small Town Girl”; "I See the Moon"; "My Nellie's Blue Eyes"; "(God Gave Us) these Wonderful Things"; "There's No Colour Bar in Heaven"; "The Ballad of the Minstrel Boy"; "Just Plain Folks"

Released: 1962

Stu Davis Souvenirs - London Records (EB. 58)

"Dear Mr. Disc Jockey"; "Wild Weed”; "Parking Meter Blues"; "I’d Be Glad to Forget You”; "Old and in the Way"; "Broken Love"; "The Legend of the Jeebi"; "Honky Tonk Serenade"; "Queen of the Twilight";

"A Wedding for Mary"

Released: 1963 
Stu Davis meets The Pathfinders and The Colonials in a Nashville Hootenanny - London Records (EB. 69)

"In the Stilly Night"; "The Song of the Violet"; "Green Grow the Lilacs" (w. The Colonials); "Get Away Old Man Get Away"; "Between Two Trees"; "The Spinning Wheel"; "In the Pines" (w. The Colonials); "Smoky Mountain Bill"; "The Ballad of a Black Sheep"; "The Girl That I Marry"

Released: 1964

Have another Helping of Stu - London Records (EB. 91)

"Have You Forgotten"; "Old Ship"; "I'm Gonna Change Everything”; "Bow River Valley"; "Names Unknown"; "Down in the Diving Bell"; "Dude in the Ten Gallon Hat"; "Fly Trouble"; "Coupon Song"; "You're a Real Good Friend"

Released: 1965

The Stu Davis Show - London Records (EB. 96)

"Roll Along Kentucky Moon"; "Oklahoma Sal”; “Abilene”; "Blindman River Break-Up"; "When the Work's All Done This Fall"; "When It's Lamplightin' Time (In the Valley)"; "The Ballad of Cowboy Jack"; "The Song of the Swallow"; "One More Ride"; "The Woodsman's Prayer"

Released: 1966

Note: credited to Stu Davis and his son Duane with the Pathfinders, Wally McDonald \& Alfie Myhre

The Sound of Country Music - London Records (EB. 103)

"Anita, You're Dreamin"'; "Devoted to You"; "Silent Trails"; "Stepping Stone"; "Have I Told You Lately (That I Love You)"; "You'll Come Walkin' Back"; "The Everlasting Hills"; "Cryin' Time"; "Teardrops in My Heart"; "Maple Sugar Sweetheart"

Note: credited to Stu Davis and Duane Davis

Released: 1966

The Stu Davis Centennial Album - London Records (EB. 107)

"A Place Called Newfoundland"; "This Is My Land"; "On an Old Covered Bridge"; "My Home in Nova Scotia"; "The Legend of the Lonesome Tree"; "The Legend of the Jeebi"; "That Old Red River Run"; "In the Valley of Qu'Appelle"; "Yonder on the Rollin' Plain"; "The Mountains of Home"; "The Homesteader's Lament"

Released: 1967

The Songs and Music of Stu Davis, Trail Ridin' Troubadour - Dominion Records (LSP 48510)

"All My Life"; "I Don't Think She Even Misses Me"; "You've Worn Out Your Welcome"; "My Special Book of Memories" (featuring Duane Davis, Banjo); "Homestead Fever"; "Outcast"; "A Garden Spot on the Moon"; "The Ballad of Banjo Bill"; "The Mountains of Home"; "Travelin' On"; "I Wonder When My Baby's Comin' Home"; "The Legend of the Lonesome Tree"

Released: 1970 
Songs from the Heart of Johnny Canuck - Birchmount Records (BM 575)

"I'm Gonna Change Everything"; "May You Never Be Alone"; "I've Got a Woman's Love"; "The Old Country Church"; "At Mail Call Today"; "Paddle Your Own Canoe"; "Love Song of the Winds"; "The Touch of God's Hand"; "Have You Forgotten"; "In Daddy's Footsteps"

Released: 1971

Let's Go Back to the Country with Canada's Cowboy Troubadour Stu Davis - Cattle Records (LP-112), Germany

"Deserted"; "Child of Divorce"; "I Looked for Love"; "In Daddy's Footsteps"; "Canadian Waltz"; "I Went to Your Wedding"; "Why Should I Send You Flowers?"; "The Dude in the Ten Gallon Hat"; "When the Snowbirds Cross the Rockies"; "Fate of the Flying Enterprise"; "Crossroads"; "What a Fool I Was" (\#1); "Land, Sky and Water"; "Welcome Back to My Heart"; "Crying for You"; "Sweetheart of Yesterday"; "Too Far Apart"; "Darlin'", "Now I Know the Reason Why"

Released: 1987

Canada's Cowboy Troubadour / Take Me Back to My Boots and Saddle - British Archive of Country Music (CD D 237), UK

"Old and in the Way"; "They're Burning Down the House I Was Brung Up In"; "Always Keep Your Promise"; "Diggin' with a Hoe"; "Welcome Back to My Heart"; "Fort Worth Jail”; "The Gangster's Warning"; "I Took It"; "I’m Gonna Leave Town"; "The Little Shirt My Mother Made for Me"; "New Broom Boogie"; "Swaller Tail Coat"; "Take Me Back to My Boots and Saddle"; "When the Snowbirds Cross the Rockies"; "The Cowboy's Prayer"; "The Dude in the Ten Gallon Hat"; "A Wedding for Mary"; "Crying for You"; "Shepherd of Mine"; "I Still Do"; "Sweetheart of Yesterday"; "Carrier Pigeon"; "What a Fool I Was"; "The Piggy Bank Song"; "Dark as a Dungeon"

Released: 2008

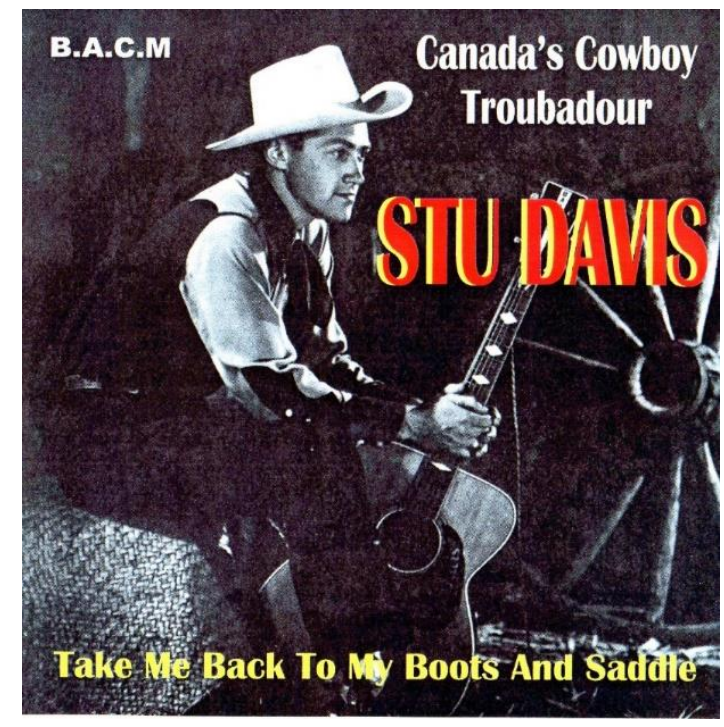

Cover of Take Me Back to My Boots and Saddle

(British Archive of Country Music, CD) 2000 
Analytical Essays

on Music by

Women Composers

SECULAR \& SACRED MUSIC TO 1900

EDITEd BY Laurel Parsons

\& Brenda Ravenscroft
Analytical Essays on Music by Women Composers: Secular and Sacred Music to 1900 . Edited by Laurel Parsons and Brenda Ravenscroft. Analytical Essays on Music by Women Composers, vol. 1. New York: Oxford University Press, 2018. 288 pp. ISBN 9780190237028.

https://global.oup.com/academic/product/ analyticalessays-on-music-by-women-composers-secular-andsacred-music-to-1900-9780190237028

Reviewed by: Roxane Prevost, University of Ottawa

Analytical Essays on Music by Women Composers: Secular and Sacred Music to 1900 is the second in a planned series of four volumes dedicated to the analysis of music by women composers. As with the first published volume, identified as volume 3 and focused on concert music from 1960-2000, each chapter in volume 1 begins with a brief biography of its composer. The works analysed date from

the Middle Ages to the late-nineteenth century and are grouped into three parts: (1) early vocal music (Hildegard, Casulana, Strozzi), (2) Baroque and Classical music (Jacquet de La Guerre, Martines), and (3) nineteenth-century music (Hensel, Lang, Schumann, Beach). Although the collection is organized chronologically, editors Laurel Parsons and Brenda Ravenscroft clarify that it deals with the analysis of distinct works, rather than suggesting an evolution of music.

As in the introduction to volume 3, Parsons and Ravenscroft affirm that this collection of essays responds to a need for more analytical studies on works by women composers. The first part of the book (chapters 2-4), entitled "Early Music for Voice," opens with Jennifer Bain's study of Hildegard of Bingen's Sequence for St. Rupert: O lerusalem aurea civitas (ca. 1150-1170). Using manuscript evidence to argue that the work is a sequence, Bain focuses on how Hildegard negotiated setting the changing text. Bain begins with the poetic text and then turns to the relationship between text and music from the small scale (syllables, words, gestures) to the large scale (phrases, verses). In chapter 3, Peter Schubert examines Maddalena Casulana's madrigal "Per lei pos' in oblio" from Cinta di fior (1570) primarily through chordal phrases. He argues that his approach differs from other scholars who consider harmony or melody as the primary focus since he treats both in his analysis. After briefly surveying common contrapuntal techniques that the composer incorporated in her works, he analyses the musical structure of "Per lei pos' in oblio" by focusing on "bass-line soggetto" (p. 53), texture, and the inclusion of an aria in the madrigal. In chapter 4, Richard Kolb and Barbara Swanson explore Barbara Strozzi's cantata

This work is licensed under a Creative Commons Attribution-NonCommercial 4.0 International License. 
Appresso ai molli argenti (1659), a lament. They discuss the structure of the text by Giovanni Pietro Monesi and explore the conventions for laments at the time the work was written. They then highlight the relationship between text and music, primarily through text painting, chromaticism, dissonances, descending-tetrachord bass pattern, tonal plan, and musical structure. They argue that Strozzi divided the lament into two parts instead of the five-part structure implied in the poetic text.

The second part of the book, "Seventeenth- and Eighteenth-Century Keyboard Music" includes two studies. In chapter 5, Susan McClary examines two sarabandes (from Suite in A minor (1687) and Suite in D minor (1707)) written by Élisabeth-Claude Jacquet de La Guerre. Rather than focusing on the score and recording, McClary turns to an aesthetic approach to draw out the richness of the works. She highlights the intricacies of the dance-feet, arms, face, hands - that would be indicated in the music. In addition, she discusses the importance of the harpsichord mechanism in allowing for control of colours and attention to the tactile, as well as the performer's touch and facial expressions, all important features in the performance of this repertoire. In chapter 6, L. Poundie Burstein analyses the first movement of Marianna Martines's Sonata in A Major (1765) focusing on phrase structure, rhythmic expansion, and large-scale tonal relationships. Burstein argues that Martines not only included conventions of the gallant style, but that she also manipulated these conventions in her works.

The third part of the book, "Nineteenth-Century Lieder and Piano Music," includes three chapters on lieder and one chapter on piano music. In chapter 7, Stephen Rogers analyses two lieder by Fanny Hensel ("Von dir, mein Lieb, ich scheiden muss" (1841) and "Ich kann wohl manchmal singen" (1846)), arguing that Hensel, whose compositional style is often associated with fantasy rather than formal conventions, created free-sounding works in a structured manner. He examines the harmonic structure to show how Hensel avoided tonics and spontaneously changed keys to accommodate the text. He also identifies harmonic schemata (chord patterns with specific scale degrees) that are unique to Hensel and that allow her to compose in such a way as to give the impression of fantasy or improvisation. In chapter 8, Harald Krebs explores two lieder ("An einer Quelle" (1840/1853) and "Am Morgen" (1840)) by Josephine Lang; he focuses on how the composer used the same texts to create two versions for each lied. He discusses the two different settings of each text by comparing harmony, meter, pulse, texture, rhythm, and formal structure, and interprets the similarities and differences in the context of events that happened in Lang's life. In chapter 9, Michael Baker analyses the large-scale structure of Clara Schumann's lied "Liebst du um Schönheit" (1841) primarily through Schenkerian analysis. He borrows the notion of interruption, which occurs multiple times and at different structural levels, to explain how Schumann set the last stanza differently from the others to reflect the poetry. In the last chapter, Edward D. Latham uses Schenkerian tools to analyse the harmony and large-scale tonal structures of Amy Beach's solo piano piece "Phantoms," opus 15, no. 2 (1892). He also focuses on timbre and register to explain some of the ways in which Beach evokes the title of the piece.

This book has much to offer, showcasing, as it does, relatively unknown repertoire and employing a variety of analytical approaches. That said, as it examines a mix of vocal and keyboard works it is less coherent than the earlier volume and less suitable to classroom use. This diversity is also a strength, with music spanning almost 700 years carefully analyzed through a wide range of methods. I highly recommend it. 


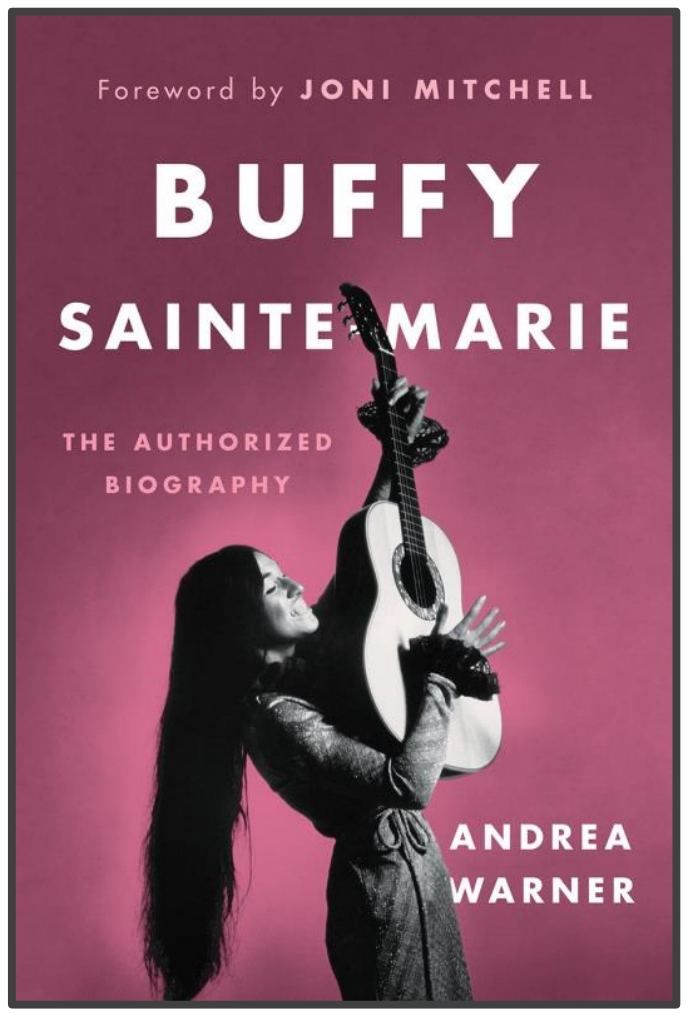

Buffy Sainte-Marie: The Authorized Biography. By Andrea Warner. Vancouver, BC: Greystone Books, 2018. 304 pp. ISBN 9781771643580.

https://greystonebooks.com/collections/andreawarner/products/buffy-sainte-marie

Reviewed by: Monique Giroux, University of Lethbridge

Cree singer, songwriter, actress, and educator Buffy Sainte-Marie has led a remarkable life. Since beginning her career nearly sixty years ago, many of her twenty-one albums - featuring mostly original songs-have pushed technological and social boundaries; and as an actress and educator, she has been a stalwart advocate for inclusion and diversity. Andrea Warner provides readers with a compelling sketch of Sainte-Marie's extraordinary accomplishments in her book Buffy Sainte-Marie: The Authorized Biography. Drawing on forty hours of formal interviews conducted in part while on the road with Sainte-Marie, Warner writes with attention to the intricate ways in which history, sociocultural shifts (some led by Sainte-Marie), and personal experiences have shaped Sainte-Marie's music, as well as her life beyond music. Her seventeen chapters are roughly chronological, with five interludes on abuse, fame, decolonization, uncertainty, and happiness -all in Sainte-Marie's own words. An example of the biographical genre at its finest, Warner's book acknowledges the hardships Sainte-Marie has faced in her personal life and as an Indigenous woman in the music industry without sensationalizing her pain or turning it into a story of success against all odds.

Given the racism and misogyny deeply imbedded in the music industry, it is not surprising that SainteMarie's abilities as a musician have all too often been downplayed and erased. In fact, it might come as a surprise to some that Sainte-Marie wrote the very popular song "Until It's Time for You to Go," covered numerous times by Elvis Presley, among other musicians, and that she co-wrote the Academy Award-winning "Up Where We Belong" (with Will Jennings and her then-partner Jack Nitzsche). She also composed "Universal Soldier" and "Cod'ine," both covered by Donovan (Donovan Philips Leitch). SainteMarie is often not credited for these songs and has even been confronted over their authorship.

Furthermore, as Warner points out, Leitch was inducted into the Rock and Roll Hall of Fame and the Songwriter's Hall of Fame, while Sainte-Marie has been inducted into neither. This erasure of SainteMarie's authorship and artistic merit, as Warner suggests, speaks to "the inherent 'authority' that

This work is licensed under a Creative Commons Attribution-NonCommercial 4.0 International License. 
society gives to men's words, [and] the weight they carry," whereas women "apparently speak in dandelion fluff and helium balloons" (p. 68). Certainly, for a musician who has written such beloved songs, it is surprising at best that her skills as a songwriter have not been more widely recognized.

Like her songwriting abilities, Sainte-Marie's musical innovations often go unacknowledged. Her third album, Little Wheel Spin and Spin (1966) featured electric guitar-revolutionary for a folk musician at the time-and was a model for future cross-genre albums. It also included "My Country 'Tis of Thy People You're Dying," which called out Canada's residential school system. Fifty years later, we have only just begun addressing the horrific abuse and genocide facilitated by these schools. With the release of Illuminations in 1969, Sainte-Marie became the first person to record an album completely in quadrophonic sound. In 1992, following a hiatus from the music business, she recorded Coincidence and Likely Stories, becoming the first person to release an album made entirely over the internet. In addition to innovations at the intersection of music and technology, Sainte-Marie promoted Indigenous musics in a way that no one was doing at the time; indeed, her music demonstrated the enduring modernity of Indigenous musical practices. This is notable in "Starwalker" (first recorded in 1976) and "Darling Don't Cry" (1996) which are both groundbreaking for their sampling of powwow singing. Many now consider her to be a trailblazer at the forefront of the contemporary Indigenous musical renaissance.

While Sainte-Marie's work has often addressed inequities, she does not position herself as a disrupter who went up against a racist and misogynistic system. As she points out, she just aims to present the facts. When she wrote songs such as "Now That the Buffalo's Gone," she offended people with her message about genocide and colonialism, but she was simply "being accurate" and had been very careful to fact check (p. 97). Sainte-Marie's humility is refreshing but should not be read as an indication that her work lacks impact. The five years (1976-1981) she spent as an actor on Sesame Street gave Indigenous children a role model at a time when there was little to no room for Indigenous people in popular culture, and her work on the television series The Virginian (1968) ensured more realistic and comprehensive representation of Indigenous people on television. To this day she is considered at the vanguard of Indigenous music, a role model to contemporary Indigenous artists and a musical messenger for Indigenous and Settler peoples alike. Her approach to social change, in her own words, centres on "offering an alternative" rather than "winning a fight" (p. 101). It is an activism that offers content rather than (just) critique.

Buffy Sainte-Marie is a must-read book for anyone who wants to better understand settler-colonialism in North America and the way in which it impacts both individuals and broader social structures. Given Sainte-Marie's musical achievements, it is also essential reading for anyone interested in folk and popular musics within North America. Despite addressing challenging and even painful issues, it is ultimately a poignant portrayal of a woman who has used compassion, grace, resilience, and fierceness as a formidable force against racism and misogyny. 


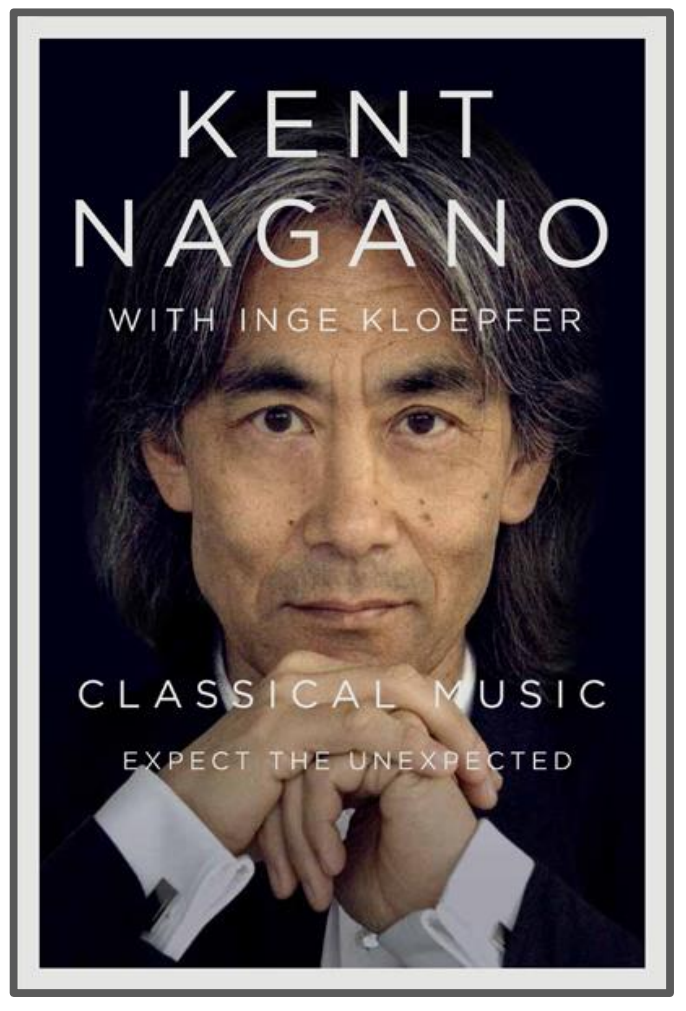

Classical Music: Expect the Unexpected. By Kent Nagano with Inge Kloepfer. Translated from German by Hans-Christian Oeser. Montreal, QC; Kingston, ON: McGill-Queen's University Press, 2019. 238 pp. ISBN 9780773556348.

https://www.mqup.ca/classical-music-products9780773556348.php

Reviewed by: Elaine Keillor, Carleton University

Seeing the author's name as Kent Nagano, the illustrious conductor, a reader might expect this book to be basically an autobiography, but the word "unexpected" was put into the title. Certainly there are interesting autobiographical chapters, but the main issue of this book is classical music, which Nagano asserts "can foster social cohesion and enhance our quality of life" (p. 79). Moreover, he argues that we need to transform "“'the crisis of classical music' into 'classical music for a time of crisis'" (p. 83).

A part of his argument is that classical music is not an elitist art form. Nagano begins by recalling his own introduction to music as a child. This took place in the small village of Morro Bay, California, where his mother began teaching music to each of her children from the age of four. However, in 1957 when Nagano was age six, the Georgian musician Wachtang "Botso" Korisheli arrived in the village and, in Nagano's words, transformed the elementary school "into a kind of musical laboratory" (p. 9). Korisheli insisted on aural training and music reading for those in the band and soon had a full-fledged orchestra in operation. On weekends he coached numerous chamber ensembles in his home, often encouraging parents of the children involved to become teaching assistants. Nagano summarizes Korisheli's impact as follows: "He metamorphosed Morro Bay into a village of sound where music helped overcome the numerous conflicts that would flare up again and again in a community of immigrants from very different ethnic backgrounds" (p. 15).

That positive experience undoubtedly formed the basis for Nagano's belief in the value and need for classical music by each and every person. Chapter 2 reviews the decline in the support for classical music in primary and secondary schools and by the media, not only in North America but

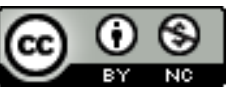

This work is licensed under a Creative Commons Attribution-NonCommercial 4.0 International License. 
broadly in Europe, where the bulk of Western classical music originated. Nagano pinpoints the initial link in the decline to the belief that "serious music is nice to have, but by no means essential" (p. 47) and refers to the bankruptcy of the Oakland Symphony Orchestra in 1986. He summarizes this crisis as a version of capitalism adopted throughout the Western world. Its premise assumes the only worthwhile life is that of being immediately profitable rather than being involved in social responsibilities and individual charitable experiences.

To argue that classical music can in large part fill this vacuum Nagano sets about exploring how the power of music can unfold and what it evokes. He refers to various writers and theorists in the process, but highlights the relevance of Northrop Frye's essay, "The Educated Imagination" (1964). ${ }^{1}$ Frye argues that the importance of the arts lies in their ability to strengthen our imaginative powers. Thus, one can envision the kind of society one wishes to live in through meaningful involvement in the arts and, in Nagano's argument, through serious music in particular.

Nagano does admit that some popular music achieves a high standard, such as "Imagine" by John Lennon (p. 170). However, the type of music that Nagano feels a person needs to hear and experience to really develop one's imagination is more complex. Chapter 5 is largely a report of his discussions with Daniel Levitin concerning the areas of the brain impacted by music. Nagano argues that listening to a work such as Bruckner's Eighth Symphony or Messiaen's Éclairs sur l'Au-Delà produces a powerful effect upon the brain. In Levitin's opinion, this is unique to music, which has a stronger impact than any of the other arts.

Among the fascinating autobiographical sections of this book are the chapters dealing with Messiaen, whose works Nagano began to program in 1978 with the Berkeley Symphony Orchestra. The composer was so impressed with the recordings of subsequent performances sent to him by Nagano that he and his wife travelled to Berkeley for the final concert in the Messiaen cycle. In the early 1980s Nagano was invited to stay at the Messiaen apartment in Paris. In Nagano's words, Messiaen and his wife, Yvonne Loriod, introduced him "to a European way of life and to a European appreciation of art" (p. 140).

Another strong influence upon Nagano was his friendship with Leonard Bernstein. With him, Nagano frequently discussed the music of Charles Ives and in particular what made Ives's music so "American," compared with the works of composers such as Copland or Sessions. But regardless of whether it was music by European or North American composers, when he became conductor of the Montreal Symphony Orchestra Nagano set himself the goal of enticing more young people to experience the power of "serious" music. At the beginning of his tenure, in 2006, there were no subscribers under the age of thirty-five. Nagano determined that orchestral music must be brought to Montrealers wherever they were, including parks and arenas. Programming was another important factor, such as pairing Ein Heldenleben with a new composition celebrating hockey heroes, or including Beethoven on a concert featuring Frank Zappa's orchestral works. With these

1. Northrop Frye, The Educated Imagination (Bloomington: Indiana University Press, 1964). 
initiatives, over one thousand subscribers under the age of thirty-four have been attracted to these symphonic concerts. In addition, beginning in 2016, Nagano headed up a project to create a musical kindergarten in an underprivileged area of Montréal-Nord, where there is ethnic/cultural diversity similar to Nagano's experience in Morro Bay (p. 128).

Nagano drives home the power of listening to and understanding serious music through the final chapter where diverse individuals expound on the power of music in their lives. The interviewees include politician Helmut Schmidt, Hollywood film director William Friedkin, basketball player Dirk Nowitzki, novelist Yann Martel, and scientist/astronaut and now Governor General of Canada Julie Payette.

Classical music for Nagano consists of the Western canon. But what about the power of art musics in non-European cultures? Some research about the impact of Carnatic and Hindustani musics upon the brain has been undertaken in the 21st century. ${ }^{2}$ These musical cultures are not referred to in the book, although Nagano does refer to Japanese Noh theatre and Balinese gamelan along with classical Indian musics having a major impact on Messiaen. For persons exposed to these nonWestern musical cultures, the evidence so far seems to indicate that it can have a powerful impact upon a listener. Is it similar to that for which Nagano is arguing with regard to works of the Western canon?

There is one reference in the book to Nagano experiencing a non-Western Indigenous culture, and that is in connection with the Montreal Symphony Orchestra's journey to the Canadian North. For that tour, a new composition by Alexina Louie, Take the Dog Sled, had been commissioned and it incorporated two Inuit women singers performing throat singing. Nagano admits: "Only, in the course of time, when I got used to the sounds and heard how people imitated nature in their singing did those sounds become a song for me" (p. 164). That experience made him realize what music is. "Music, physically nothing more than an acoustic stimulus, whether a single chord, an arrangement of tones, an entire symphony or an Inuit song, basically originates in our own head and then spreads all the more powerfully within us" (p. 165). The key then, it seems to this reviewer, is that a person has exposure to a wide range of types of music to fully be impacted in the way for which Nagano argues.

2. See Satish Kumar, Pavana Krishnamoorthy, Shwetha Rao, and Santhosh Kumar. "A Study on Effect of Indian Classical Music on Brain Activity Using EEG Signals," Journal of Medical Science and Clinical Research 5 (May 2017): 21702-6; Ram K. Nawasalkar and Pradeep K. Butey, "Analytical and Comparative Study on Effect of Indian Classical Music on Human Body Using EEG Based Signals," International Journal of Modern Engineering Research 2, no. 5 (Sept-Oct, 2017): 3289-91; and Sravanti L. Sanivarapu, "India's Rich Musical Heritage Has a Lot to Offer to Modern Psychiatry," Indian Journal of Psychiatry 57, no. 2 (Apr-Jun, 2015): 210-13. 


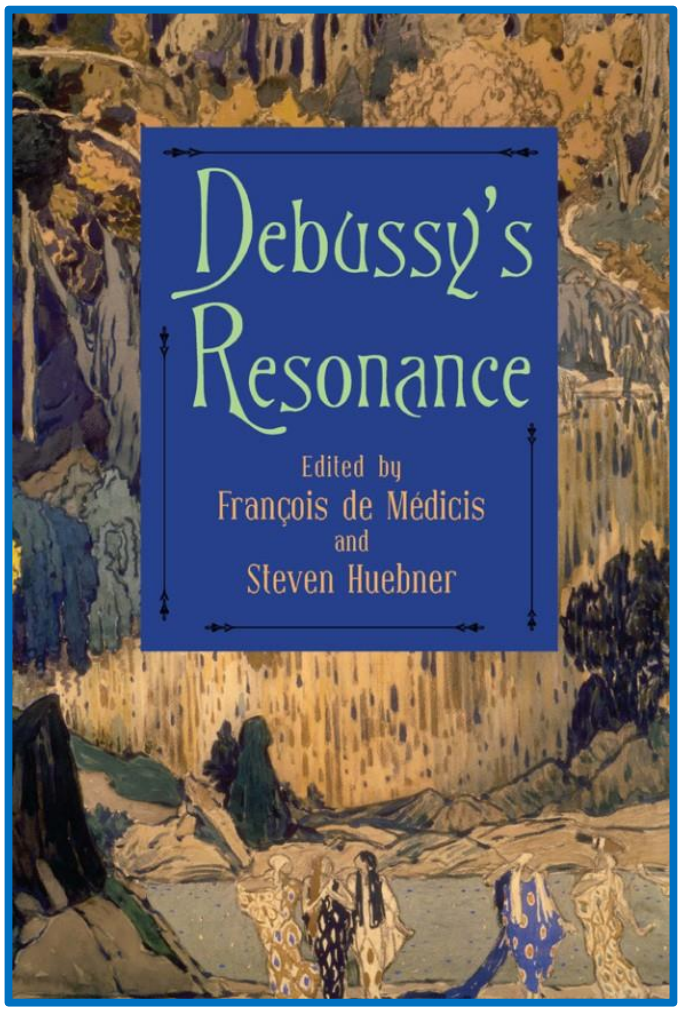

Debussy's Resonance. Edited by François de Médicis and Steven Huebner. Eastman Studies in Music. Rochester, NY: University of Rochester Press, 2018. 640 pp. ISBN 9781580465250.

https://boydellandbrewer.com/debussy-sresonance-hb.html

Reviewed by: Edward Jurkowski, University of Manitoba

Like the seemingly endless stream of new audio recordings, the body of Claude Debussy scholarship continues unabated, with no sign of slowing down. This latest important collection of essays stems from a bilingual conference held at the Université de Montréal in 2012 to celebrate the 150th anniversary of Debussy's birth. By a stroke of fortune, there is a nice symmetry to this book, as its publication corresponds with the $100^{\text {th }}$ anniversary of the composer's death. Debussy's Resonance celebrates the multifarious influence of Debussy upon twentieth-century music as well as the extensive range of analytical methodologies that have developed-especially within the past thirty years. To this point, the editors note that James Briscoe's seminal Claude Debussy: A Guide to Research (1990) lists approximately 900 secondary sources. Remarkably, in the introduction de Médicis and Huebner identify that a recent RILM search shows this number had risen by an astounding $150 \%$ since 1990, to nearly 2,300 . Such a surge of research naturally leads one to ask if there was anything more to be unearthed or said about this seminal modern composer. Yet given the breadth of inquiry in Debussy's Resonance, I am left with the sense that we have only scratched the surface of this endlessly fascinating composer and the impact that his body of work has had during the past hundred years.

Following the editors' introduction, the book contains twenty chapters placed within five parts. Part One, "Historiographical and Editorial Issues," contains four chapters. Richard Langham Smith's opening essay “Debussy Fifty Years Later: Has the Barrel Run Dry?” offers a high-level view of how our perspective of the composer has changed since his centenary celebration in

This work is licensed under a Creative Commons Attribution-NonCommercial 4.0 International License. 
1962. In his thoughtful text Langham Smith considers how the changes in musicological approaches, the greater availability of early twentieth-century performances, and even the changes in the staging of Debussy's opera during the intervening fifty years have deepened our understanding of the composer and the cultural context in which he created his enduring music. In the second chapter, Roy Howat discusses the thirty-year journey of the Oeuvres complètes de Claude Debussy. Intriguingly, Howat provides several illustrations of how Debussy's Welte-Mignon recordings have played a vital role in the editorial work of some of the volumes (on p. 42 Howat suggests that this critical edition may be the first to use a composer's recording in such a manner). In "The Kunkelmann Manuscripts," Denis Herlin discusses the nine autographs of early Debussy songs from a collection dedicated to the composer's friend Henry Kunkelmann. The collection is valuable on two counts. First, there are four songs previously unknown to Debussy scholars. Second, the remaining songs are revisions or modifications to several of the early Marie Vasnier songs, giving us an important window into Debussy's compositional methods from this point in his career. In his "'Paysage sentimental': Si doux, si triste, si dormant ...," David Grayson uncovers the convoluted history of the three versions of one of Debussy's early songs. Concomitantly, Grayson outlines how the three versions provide a window into the composer's stylistic evolution over two decades.

Part Two encompasses the book's largest number of chapters-five. David Code, in "The 'Song Triptych'," studies how the song triptych dominated Debussy's approach to song writing beginning around 1890. Rather than study these post-1890 songs in isolation, what has been traditionally the norm thus far, Code uses interdisciplinary tools to suggest influences and a rationale for the grouping of these songs. In his fascinating "Composing after Wagner," François de Médicis places into context Debussy's operas Rodrigue et Chimène and, in particular, Pelléas et Mélisande with Alfred Bruneau, considered the leading figure of a fringe group of late nineteenth-century French composers who looked to forge an alternative compositional path to that of Wagner. The influence of another important nineteenth-century French composer, Jules Massenet, on Debussy's stylistic development is explored in Steven Huebner's absorbing "Between Massenet and Wagner." Robert Orledge outlines the latent orchestral sounds in Debussy's piano music in "Debussy's Concept of Orchestration." More intriguingly, Orledge suggests that his orchestral music was conceived in instrumental terms to a much greater degree than the manuscripts indicate. Although Orledge details the role two important Debussy collaborators, André Caplet and Charles Koechlin, played in completing many of his orchestral scores, I hope that a future study investigates the reciprocal relationship-that is, how Debussy's music influenced the orchestral writing of these two vital, early twentieth-century composers. Rounding out Part Two is Marie Rolf's exploration of non-French influences on Debussy's formative years in "Oriental and Iberian Resonances in Early Debussy Songs," by focusing upon two early, unpublished songs "Rondel chinois" and "Séguidille" (in fact, the two songs only became publicly available in 2013 and 2014, respectively). 
Michel Duchesneau's "Debussy and Japanese Prints" opens Part Three, entitled "History and Hermeneutics." Here, Duchesneau explores aspects of this art he believes were attractive and influential to Debussy. Katherine Bergeron in "Secrets and Lies, or the Truth About Pelléas" expands upon prior writings by Jane Fulcher and Jann Pasler about "truth" in Debussy's opera, and investigates how truth is found in what she perceives as a concealed space between the relationships of unusual orchestral associations and the failure of dialogue on the stage. Two chapters round out Part Three: Julian Johnson, in "Vertige!: Debussy, Mallarmé, and the Edge of Language," examines how disorientation is achieved between the relationship of word and music in Debussy's late Mallarmé settings; while August Sheehy's “'Les sons ... tournent': Debussy, the Waltz, and Embodied Hermeneutics" uncovers another type of disorientation within the listener's body with his analysis of the piano prelude "Les sons et les parfums tournent dans l'air du soir."

Part Four is more theoretical in focus. In "Follow the Leader," Matthew Brown explores the means by which Debussy employs contrapuntal textures in four works, using the nursery rhyme "Nous n'irons plus au bois." Brown's study identifies the role of counterpoint in Debussy's music, as well as contextualizes Debussy's statements about the contrapuntal basis of harmony. Mark DeVoto, in "Debussy's Absolute Pitch: Motivic Harmony and Choice of Keys," traces the role certain harmonic sonorities play in various Debussy works. This interesting study also explores the harmonic association DeVoto has called "bifocal relationship" in Pelléas et Mélisande, one associating E Major and C-sharp minor, noting the dramatic implications that occur with these particular harmonic moments. Boyd Pomeroy puts forward a different type of harmonic practice in "Debussy's G\#/Ab Complex." In this absorbing study, Pomeroy traces the role of this pitch class in conjunction with a number of bass pedal points in works that span the composer's career. Given Debussy's pervasive use of the complex one hopes that a future study will expand Pomeroy's absorbing work to explore any extra-musical association Debussy may have had with this harmonic element. In "The Games of Jeux," Mark McFarland adds to the growing body of scholarly work on Stravinsky's influence on Debussy's post-1910 works. Here, McFarland compellingly demonstrates that Richard Taruskin's principle of "accumulation" - the process of beginning something quietly and building this element to a concluding frenzy-is the governing component of Stravinsky's seminal ballet Le Sacre du printemps and, similarly, the primary organizing element of Jeux.

Part Five, "Performance and Reception," contains three chapters. Jocelyn Ho's essay "Debussy and Late-Romantic Performing Practices" studies the composer's famous 1912 Welte-Mignon piano rolls to address a fascinating question: how does Debussy the performer, a pianist steeped in late-Romantic style of performance practice, align with our perception of Debussy's music and today's performance aesthetic, with its focus upon fidelity of the score? Carolyn Rae, in "Marius-François Gaillard's Debussy," briefly outlines the importance of this early twentieth- 
century pianist, and the unfortunate circumstances that led to Gaillard's decline in popularity, particularly during the Second World War - an unfortunate situation, for Gaillard represents an essential element in the first generation of Debussy interpreters. "Fashioning Early Debussy in Interwar France," is authored by Barbara L. Kelly and examines the challenging narratives towards the value of the pre-1890 works that began to appear in the 1920s.

The book concludes with a list of contributors and an index. The text of Debussy's Resonance is clear, extremely readable, and free of fussy problems - not surprising, given the strength of the contributors and talent of the two editors. Overall, the production and editorial work is excellent. One feature of praise is the impressive quality of the musical examples. The text is appropriate enough for the music enthusiast; at the same time, the degree of analytical discourse will appeal to the specialist/scholar. In other words, the level of the prose will appeal to a broad range of individuals interested in a variety of topics associated with this seminal early twentieth-century composer. As a final comment, the hard cover format contains very good quality paper and a solid binding.

To sum, this is an impressive collection of essays, and I courteously predict that Debussy's Resonance will be read and referenced for years to come as a vital contribution of Debussy scholarship. 


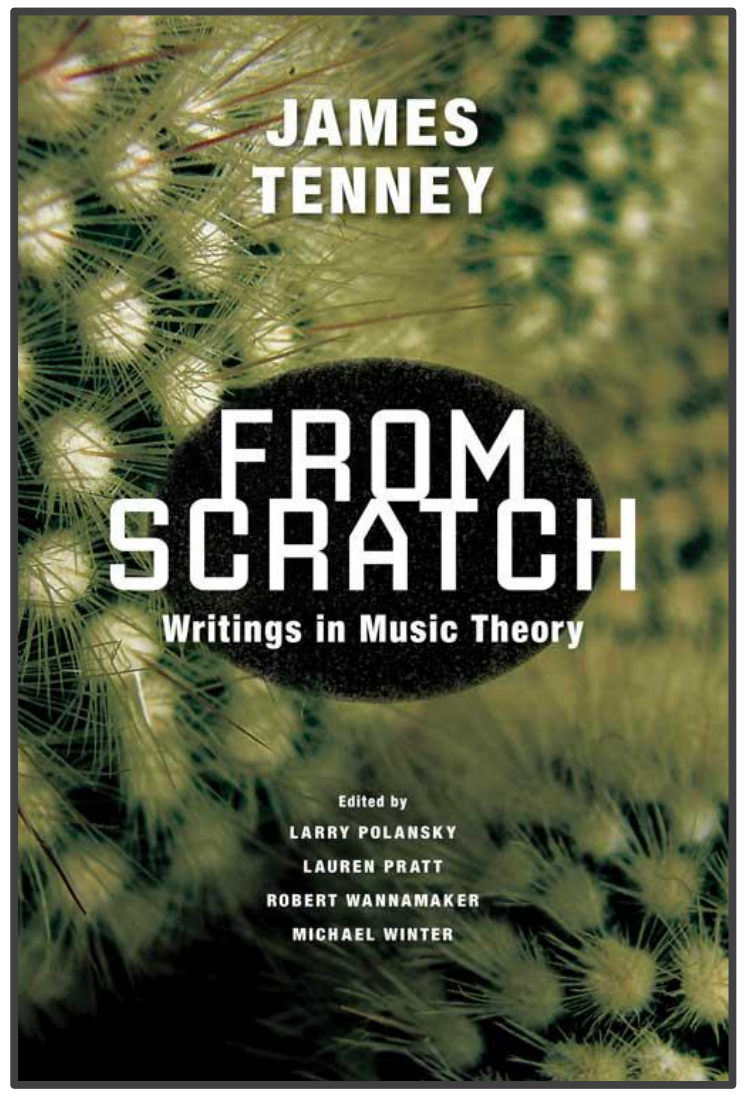

From Scratch: Writings in Music Theory. By James Tenney. Edited by Larry Polansky, Lauren Pratt, Robert Wannamaker, and Michael Winter. UrbanaChampaign: University of Illinois Press, 2015. First Paperback Edition, 2019. 467 pp. ISBN 9780252084379.

https://www.press.uillinois.edu/books/catalog/ 78det $5 \mathrm{~km} \cdot \mathrm{html}$

Reviewed by: Lelland Reed, Nova Scotia College of Art and Design

From Scratch: Writings in Music Theory by James Tenney, edited by Larry Polansky, Lauren Pratt, Robert Wannamaker, and Michael Winter, brings together the theoretical writings of one of the twentieth century's most exploratory composers and musical thinkers. First published in 2015, this text is freshly reissued in paperback. From Scratch is a selection of twenty-two of Tenney's writings - an assemblage from his seminal books, journal articles, and previously unpublished works, organized chronologically. The collection spans Tenney's long career, representing, in the words of Larry Polansky, "the most abstract and fundamental of his prose, perhaps the musical embodiment of his occasional self-description as "amateur cosmologist" (p. xii). The editors all worked closely with Tenney before his death in 2006 to bring together the works in this collection, which are essential reading for any researcher interested in Tenney, twentieth-century music, and technology in music. For the readers of CAML Review, this compilation will be of particular interest. Between 1976 and 2000 Tenney taught music history, theory, and composition at York University, where in 1994 he was given the honour of distinguished research professor. ${ }^{1}$ Tenney worked with giants such as John Cage and Edgar Varèse, among others, and, as such, was a Canadian link to the experimental developments happening in the US during the last quarter of the twentieth century.

1. Betty Nygaard King and F. Tim Knight, "James Tenney," in The Canadian Encyclopedia, Historica Canada, published December 6, 2006; last modified December 16, 2013, https://www.thecanadianencyclopedia.ca/en/article/james-tenney-emc.

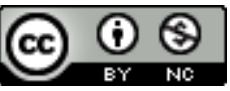

This work is licensed under a Creative Commons Attribution-NonCommercial 4.0 International License 
In his introduction, Polansky provides insights into the compilation of this volume, structuring his essay around three themes: Meta + Hodos and related writings, writings on harmony, and writings on specific pieces. Polansky's understanding of the interwoven relationship of Tenney's works is particularly beneficial to a reader who is new Tenney's work. Additionally, those who are wanting to deepen their knowledge of Tenney's analyses, algorithms, and theories will find Polansky's background with the works enriching.

Unique, notable, and first published in this collection are three articles that predate the seminal 1961 Meta + Hodos. $^{2}$ The influence of Gertrude Stein and John Cage on Tenney's early writing and musical thinking is evident in Pre-Meta + Hodos (1959), in which he writes, "The first fact is the act of listening, which, when nothing more, is living, and listening to this living, which we know as SILENCE" (p. 406). Written the same year, "On the Development of the Structural Potentialities of Rhythm, Dynamics, and Timbre in the Early Nontonal Music of Arnold Schoenberg" (1959) is an analysis of the music of Schoenberg focusing on nonharmonic traits including rhythm, dynamics, and timbre. Here, Tenney proposes a new approach to the study of twentieth-century music, one that steps away from atonal and serial theory. "On Musical Parameters" (1960-1961) is an early exploration of Tenney's interest in the attributes of perceived sound, and was initially intended to be included between sections of Meta + Hodos (1961). These three formative writings are a look into Tenney's theoretical ideas before Meta + Hodos; ideas that would be developed and apparent in later writings, including "Computer Music Experiences" (1964) (chapter 3), "John Cage and the Theory of Harmony" (1983) (chapter 12), and "The Several Dimensions of Pitch" (1993/2003) (chapter 17), among other essays, many included in this collection.

For someone who thought of himself as only "occasionally a theorist" (p. 380), Tenney had throughout his life developed profound and original ideas regarding music and harmonic perception. As Polansky writes, "Tenney wrote prolifically. The articles in this volume are just a part of his output, describing the most important theoretical ideas of his music" (p. xii). James Tenney's From Scratch: Writings in Music Theory is an essential addition to library collections with a focus on twentieth-century and experimental music and arts. The collection contains thorough supplementary information, including Tenney's written figures, tables, and examples, appendices, a section on the publication history of the essays, notes, and an index prepared by Amy Beal. From Scratch is the most current and seminal compilation of Tenney's writings, thoughtfully compiled by editors who worked closely with him during his life. This collection illustrates the principal theories of a twentieth-century leading composer and theorist deserving of this carefully edited publication.

2. James Tenney, Meta + Hodos: A Phenomenology of 20th-Century Musical Materials and an Approach to the Study of Form and Meta Meta + Hodos, 2nd ed. (Oakland, CA: Frog Peak Music, 1988). 


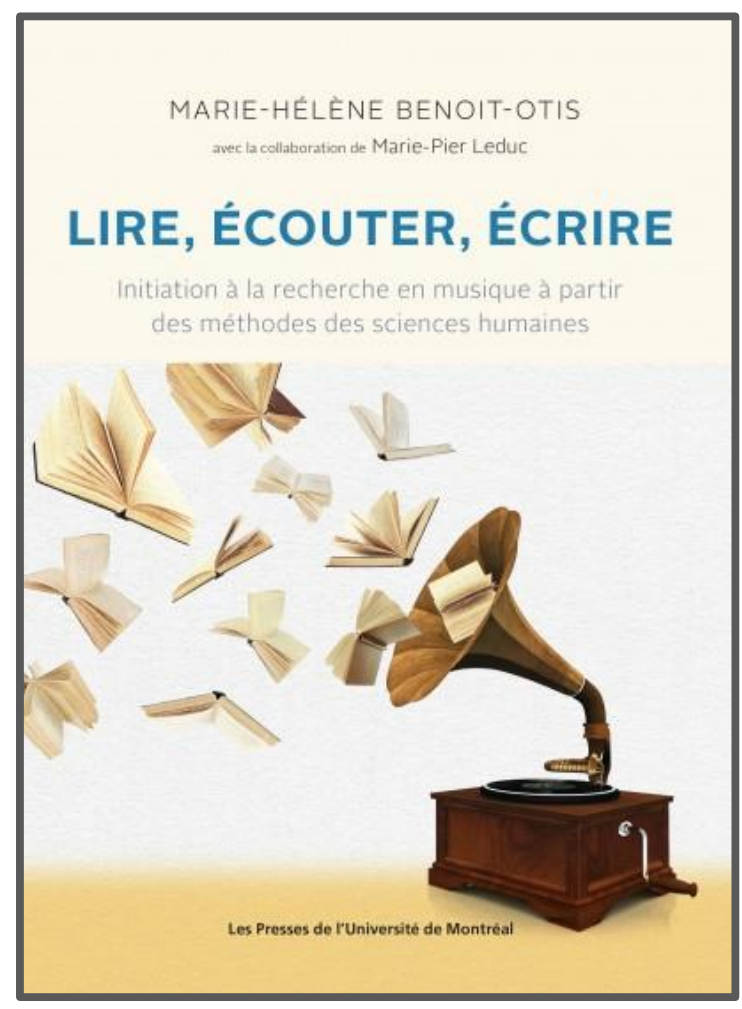

Lire, écouter, écrire : Initiation à la recherche en musique à partir des méthodes des sciences humaines. Marie-Hélène Benoit-Otis, avec la collaboration de Marie-Pier Leduc. Montréal, Les Presses de l'Université de Montréal, 2018. 256 pp. ISBN 9782760639393.

https://www.pum.umontreal.ca/catalogue/lireecouter-ecrire

Compte rendu de Tristan Paré-Morin, Université de Pennsylvanie

La rédaction d'un premier travail de recherche universitaire en musicologie est un exercice intimidant pour de nombreux étudiants. Marie-Hélène Benoit-Otis et Marie-Pier Leduc, l'une professeure en musicologie à l'Université de Montréal, l'autre doctorante à cette université, tentent de répondre à ce problème dans un ouvrage qui allie manuel pédagogique et outil de référence à l'écriture : Lire, écouter, écrire : Initiation à la recherche en musique à partir des méthodes des sciences humaines. Les auteures y offrent un ensemble de leçons, conseils et stratégies faciles d'approche pour guider les étudiants à travers les différentes étapes de leur recherche. L'ouvrage tire sa force de la concision de ses explications, du nombre et de la qualité de ses exemples, et de son approche principalement centrée sur la musicologie. Lire, écouter, écrire est donc adapté en premier lieu aux besoins des étudiants de premier cycle universitaire (et à leurs professeurs de méthodologie).

L'ouvrage se découpe en trois parties, portant d'abord sur la préparation du travail puis sur sa communication autant orale qu'écrite, et se terminant avec de brefs conseils sur la prise de notes de cours et l'écriture de comptes rendus de conférences ou de lectures. Tout au long du volume, on suit le développement de deux travaux rédigés par des étudiants à partir du choix d'un champ de recherche général jusqu'au travail final d'une dizaine de pages. Cela permet d'illustrer de façon concrète et efficace la méthodologie spécifique à la recherche en musicologie (et, de manière générale, en sciences humaines) et d'acquérir de bonnes habitudes de travail.

Dans la première partie, le livre aborde le choix du sujet, la recherche et la rédaction du plan, des fiches de lecture et de la bibliographie. Les auteures mentionnent différentes approches (historique, analytique, etc.), mais le livre ne met pas l'accent sur celles-ci, étant d'abord un manuel d'initiation

This work is licensed under a Creative Commons Attribution-NonCommercial 4.0 International License. 
plutôt qu'un ouvrage avancé de méthodologie en musicologie. Quant au chapitre portant sur les normes de présentation d'une bibliographie, il a l'avantage d'être abondamment détaillé et fournit au lecteur un bon nombre d'exemples de catégories de références propres à la musique qui sont souvent absents des manuels généraux ou des logiciels de gestion bibliographique, tels le fac-similé, l'édition critique de partition, ou l'enregistrement sonore. Les sujets traités dans la seconde partie incluent la préparation d'un exposé oral, le plagiat, l'utilisation de citations et les règles typographiques. Il est ici question de conseils pratiques à suivre et d'usages à proscrire. Trois listes de contrôle présentées en annexe offrent un aperçu rapide de toutes ces normes pour faciliter le travail de mise en page et de révision. Les deux travaux finaux d'étudiants qui sont inclus ne sont donc que deux (et peut-être pas les plus importants) des très nombreux exemples annotés qui rehaussent l'intérêt pédagogique de l'ouvrage.

Malgré ses qualités évidentes pour l'initiation à la recherche et à l'écriture, l'ouvrage ne présente pas les mêmes avantages en tant qu'outil de référence. On peut imaginer que pour la plupart des lecteurs, une fois le premier survol parcouru, ce genre d'ouvrage peut être particulièrement utile pour répondre aux questions qui surviennent durant la recherche et la rédaction. Or, l'ouvrage étant dépourvu d'un index et la table des matières ne détaillant pas les sous-titres des chapitres, il peut être fastidieux de trouver une information spécifique en dehors des quelques listes de contrôle. Par exemple, les logiciels bibliographiques sont décrits dans la section "Comment classer les fiches de lecture ? " à la fin du chapitre 5 et non pas au chapitre précédent qui traite de la préparation d'une bibliographie. Quant à la bibliographie elle-même de Lire, écouter, écrire, elle propose un mélange d'ouvrages divers, rédigés en plusieurs langues, qui semblent viser davantage l'intérêt d'un professeur que celui d'un étudiant de premier cycle. En effet, les deux premières entrées qu'on y trouve sont l'incontournable logiciel Antidote suivi du Dizionario degli editori musicali italiani 1750-1930 de Bianca Maria Antolini, dont la pertinence ici est discutable. À notre époque, où il est difficile pour de nombreux étudiants d'identifier des ressources numériques fiables, on aurait préféré trouver, en plus des ouvrages didactiques imprimés, un répertoire de catalogues et encyclopédies en ligne (Grove, RILM, etc.), un rappel condensé des logiciels (Zotero, Endnote ou autres), ou, à tout le moins, un index de sites internet de bibliothèques qui offrent déjà un condensé de ce type d'information. ${ }^{1}$ Quoique certaines références spécifiques (les plus importantes) soient mentionnées à quelques endroits dans le texte, les étudiants de premier cycle sont généralement peu informés des outils qui sont indispensables pour toute recherche en musique.

Malgré ces quelques faiblesses, le livre Lire, écouter, écrire que nous proposent Marie-Hélène BenoitOtis et Marie-Pier Leduc contribue grandement au maigre corpus francophone en méthodologie de recherche. Le texte est concis, clair et agréable à lire et la mise en page est aérée, facilitant l'accessibilité de l'ouvrage, qui est à recommander à tout étudiant de premier cycle en musique qui devra rédiger des travaux écrits. Les étudiants de maîtrise ou de doctorat, quant à eux, bénéficieront peut-être des rappels de règles typographiques ou bibliographiques, mais ne doivent pas espérer trouver ici les outils nécessaires à la rédaction d'un mémoire ou d'une thèse.

1. À titre d'exemple, on peut consulter les ressources de l'Université de Montréal : https://bib.umontreal.ca/art-cinema-musique/musicologie. 


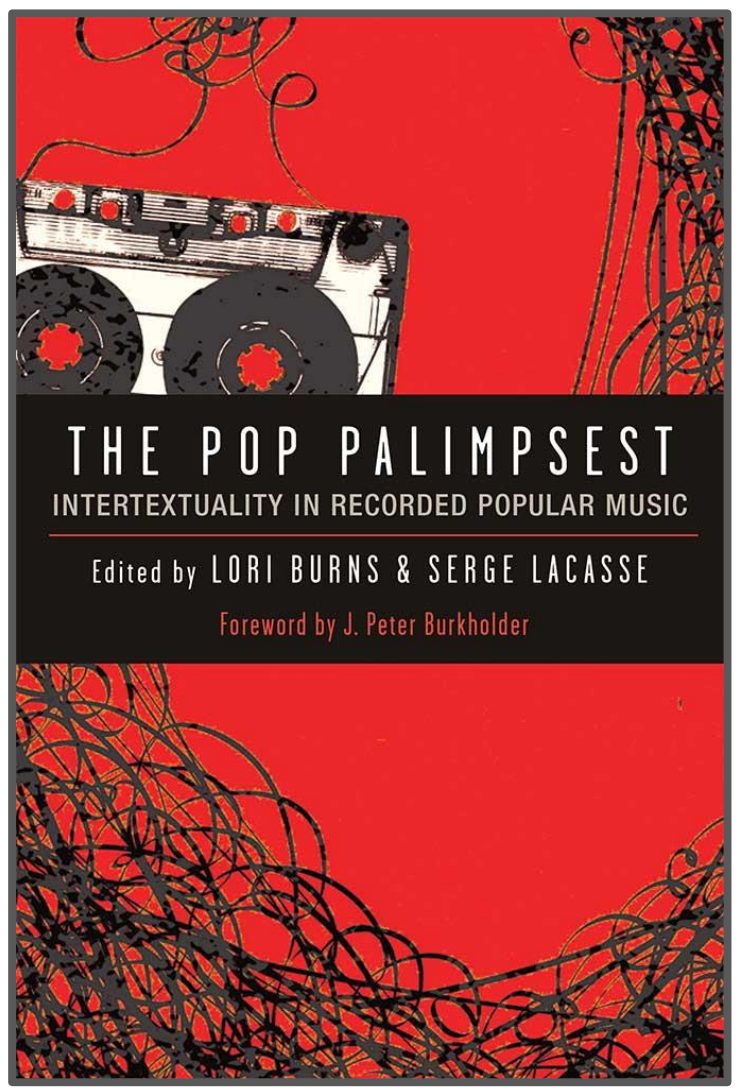

The Pop Palimpsest: Intertextuality in Recorded Popular Music. Edited by Lori Burns and Serge Lacasse. Ann Arbor: University of Michigan Press, 2018. 360 pp. ISBN 9780472130672.

\section{https://www.press.umich.edu/9755813/} pop palimpsest

Reviewed by: Stephanie Bonjack, University of Colorado Boulder

It's always exciting to dive into a work that attempts to break new ground. In The Pop Palimpsest, the editors argue that theirs is the first publication to specifically consider intertextual relationships in recorded popular music. Their approach is both overarching and local; the collection mixes analyses of single songs with bird's-eye views of genres as well as

methodologies and theories for examining intertextual relationships. The essays are arranged into four sections: Transtextualities, Intertextual Analyses, Intermedial Subjectivities, and Intertextual Productions.

Section I consists of two essays which can be considered anchors for the volume, as subsequent authors reference them, especially the first, Serge Lacasse's "Toward a Model of Transphonograpy." In it, Lacasse adapts Gérard Genette's literary model for transtextuality for sound analysis, developing five terms / concepts for use and demonstrating their application through specific examples. It's unfortunate that his example of metaphonograpy (evaluation) inaccurately describes the journal Notes as "exclusively devoted to reviews of music-related productions (books, digital media, printed music and so forth)" ( p. 35) when in fact it is a toptier peer-reviewed journal of music librarianship that also includes reviews. Still, it will be interesting to see if Lacasse's methodology is applied in future scholarship and which facets scholars might be drawn to. The subsequent chapter in this section also concerns Gérard Genette's work on intertextuality. Roger Castonguay applies Genette's theory of

This work is licensed under a Creative Commons Attribution-NonCommercial 4.0 International License. 
hypertextuality to the album A Trick of the Tail (1976) by the band Genesis, thus demonstrating a full-scale analysis in this style.

Section II: Intertextual Analyses includes five essays that dive into intertextual relationships. The first, by Allan Moore, is a reprint of an article he published in 2007 about covers of Leonard Cohen's "Hallelujah." Moore examines Jeff Buckley's 1994 version of the song as well as covers by John Cale and Rufus Wainwright associated with the film Shrek. Moore's analysis, drawing on data from internet fan sites, raises an interesting problem as his sources are no longer extant-making it impossible to know what content (and voices) he chose to use and what he left out. Additionally, I would argue that given the song's continued popularity, Moore's introduction to the article would have been an ideal place to comment on subsequent covers of the song that have been culturally significant, notably k.d. lang's rendition which appeared on her 2004 album Hymns of the 49th Parallel. She also performed it at the 2010 Vancouver Olympic Games.

Mark Spicer's essay "The Electric Light Orchestra and the Anxiety of the Beatles' Influence" examines the artistic climate in which artists worked during the Beatles' heyday and shortly thereafter. He closely analyzes a few songs by the ELO and their relationship with the Beatles' oeuvre. Spicer argues that ELO profited from these connections whereas other groups fared less well. Walter Everett's "'If You're Gonna Have a Hit': Intratextual Mixes of Edits of Pop Recordings" is an historic catalogue of song edits and versions on physical media. It's a fascinating look at how a song is sliced, diced, and manipulated for the sake of marketing and promotion. He seeks to draw a connection between a decades-old practice and the modern landscape of mash-up collaboration. "Someone and Someone: Dialogic Intertextuality and Neil Young" by William Echard considers Young's shifting personal identity throughout his career and proposes a series of lenses through which we might examine Young. The final article in this section, "Intertextuality in the Nineteenth-Century French Vaudeville" by Mary S. Woodside, offers a refreshing divergence from the 20th and 21st centuries. She examines the use of popular tunes in both vaudeville and opera and creates a framework in which to compare the use of a popular tune from two different vaudevilles.

Section III: Intermedial Subjectivities is comprised of two essays that examine performative identities. In "Rap Gods and Monsters: Words, Music, and Images in the Hip-Hop Intertexts of Eminem, Jay-Z, and Kanye West" by Lori Burns and Alyssa Woods, the authors dissect three songs by these artists that explore mythmaking and notions of godhood. Burns and Woods's analysis considers intertextuality as it applies to the songs themselves, as well as the cultural and multimedia landscapes in which they were created. The second article in this section is Stan Hawkins's "Performative Strategies and Musical Markers in the Eurythmics' 'I Need a Man.'” In it he seeks to examine the idiolect of Annie Lennox and her performance of gender. He views 
this through the various lenses of cock-rock, glam rock, drag, and camp. He takes a singular performance that he refers to as "feisty" and "spellbinding" (p. 252) and makes the argument that it "encapsulates the Eurythmics' impact on popular music" (p. 266).

In the final section, Simon Zagorski-Thomas offers a theoretical approach to the palimpsest prompt. He looks at electronic music and how specific sounds function as a text that the listener references and contextualizes based on existing memory. Justin A. Williams's piece, "Intertextuality and Lineage in The Game's 'We Ain't' and Kendrick Lamar's 'm.A.A.d. City'” places gangsta rap artists within a musical lineage. Finally, Serge Lacasse and Andy Bennett's contribution "Mix Tapes, Memory, and Nostalgia" considers mix tape communities and the deep dives they perform in order to generate texts with new meanings (compilations) from existing works.

Overall, the essays in this collection are engaging and present a body of work advancing toward something new. The editors' efforts toward incorporating well-established scholars who contributed chapters grounded in their areas of expertise is to be commended. However, the underrepresentation of women makes it hard to accept this picture as complete. Women are sorely lacking on all levels - as contributors, as sources of musical examples, and as the foci of essays. That the only essay in this collection on a female subject is about Annie Lennox performing "I Need a Man" is disheartening. I hope that future work on intertextuality in pop music will seek to counter this bias and include a broader spectrum of voices. 


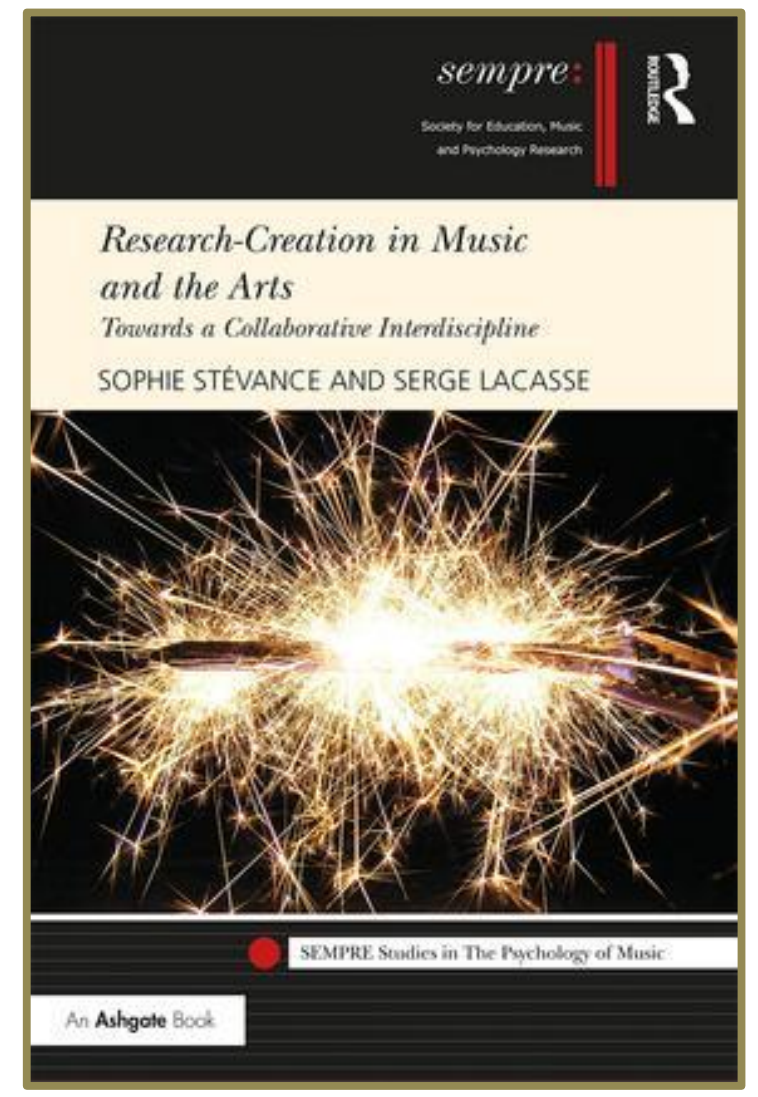

Research-Creation in Music and the Arts: Towards a Collaborative Interdiscipline. By Sophie Stévance and Serge Lacasse. London and New York: Routledge, 2018. 178 pp. ISBN 9781472486073.

https://www.routledge.com/Research-Creation-inMusic-and-the-Arts-Towards-a-CollaborativeInterdiscipline/StevanceLacasse/p/book/9781472486073

Reviewed by: Allyson Rogers, McGill University

Combining interdisciplinary research and a wide range of artistic practices, "research-creation" is a relatively recent concept in the arts and humanities. As pioneering experts, Sophie Stévance and Serge Lacasse have written a compact treatise that aims to clarify the objectives, outcomes, and benefits of research-creation in the university context. Both Stévance and Lacasse are professors of musicology at l'Université Laval in Quebec City, where Stévance holds the Canadian Research Chair in ResearchCreation in Music and where each directs a research-creation lab. Research-Creation in Music and the Arts is largely an English translation of their 2013 book, Les enjeux de la recherche-création en musique; however, the examples have been updated and the structure reorganized. ${ }^{1}$ This book is especially welcome given that "research-creation" is easily confused with similar-sounding terms such as "arts-based research," "research-led practice," or "practice-based research." Here, Stévance and Lacasse explain precisely what distinguishes research-creation, what constitutes a researchcreation project, and how to involve students in the process. The book is divided into three large chapters. In chapter 1, the authors discuss the role of fine arts within North American and European universities from the mid-twentieth century onwards, with a particular focus on the Quebec system. Chapter 2 describes some of the specific challenges that are encountered in developing research-creation projects in university music faculties and training students in this area. In chapter 3 , the authors offer a precise definition of research-creation, delimit its scope, and provide recommendations concerning best practices and methodological approaches.

1. Sophie Stévance and Serge Lacasse, Les enjeux de la recherche-création en musique (Presses de l'Université de Laval, 2013).

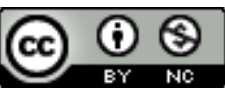

This work is licensed under a Creative Commons Attribution-NonCommercial 4.0 International License 
Stévance and Lacasse begin by outlining the history and challenges of integrating artistic disciplines into research institutions where the role of artists and their relationship to research faculty and programs have not always been clear. In doing so, they make four key observations about researchcreation. Their first claim is that "musical creation is not synonymous with theoretical research" ( $p$. 24). They immediately wade into debates about the epistemological distinctions between artistic and academic training, processes, and production, which underpinned countless discussions within fine and performing arts departments since the middle of the twentieth century. At issue are questions about how art contributes to knowledge; whether standardized artistic training hinders the unpredictability, diversity, and freedom characteristic of artistic creation; and whether, for the purpose of obtaining tenure and promotion, artistic works should be considered equivalent to academic publications. Stévance and Lacasse are adamant that music performances (concerts and recordings) are not equivalent to academic publications because art and research are entirely distinct ways of knowing-with different objectives, methods, and outcomes. This leads to their second assertion, namely that "a music concert is not an academic publication" (p. 40). They underpin this position with the proposition that academic research is intended to produce generalized knowledge via a systematic understanding and awareness of a field of study, typically resulting in some form of written peer-reviewed publication, whereas art objects are the unique expression of an artist's worldview; therefore, they are neither propositional in nature nor are they typically expected to generate knowledge in and of themselves, although different forms of knowledge may be embodied within them (p. 31). Throughout the book, while Stévance and Lacasse spend considerable time showing how broadly the term "research" is used in different contexts and specifying what constitutes academic research, they spend little time theorizing art. There is an implicit assumption that the confusion around research-creation primarily revolves around a misunderstanding about academic research and not artistic creation. Their conception of art as the individual expression of human interiority is a particularly Western notion and one that could be considered rather narrow in contemporary art discourses.

Stévance and Lacasse make no claims about these epistemological debates being resolved or resolvable. Their purpose is to show how research-creation mobilizes the strengths of two discrete ways of knowing and generates productive collaborations between artists and researchers, therefore making a unique form of scholarly and artistic contribution. "Research-creation is not research on one side and creation on the other," they write, "rather, it is an interepistemology in which the two sides are interdependent" (p. 29). Along these lines, they insist that a primary tenet of research-creation is that it must produce both research output that meets rigorous scholarly standards and a work of art. This is related to their third claim: "research-creation is not selfcontemplation" (p. 45). Studying and documenting the creative process (especially self-analysis) does not satisfy the research component of research-creation based on their definition. Similarly, the kinds of research artists undertake for a particular project seldom meets the scholarly rigor or intent that Stévance and Lacasse require. 
Their fourth observation - and one upon which they insist repeatedly-is the notion that researchcreation should be determined by the substance of the collaborative project and not by the profile or methodology of any one individual (p. 50). Although individual-centered projects are possible, a project-centered approach is more realistic for most faculty members who are typically specialized in either academic research or artistic practice. Furthermore, collaborative projects create a dialogue that helps bridge the gap between artistic and academic cultures at the university. At its best, Stévance and Lacasse purport, "a research-creation project guarantees non-hierarchical, egalitarian and democratically collaborative connections insofar as the expertise of the various agents (researchers, research-creators, and creators) are recognized and placed at the service of a common project" (p. 83). Finally, the most comprehensive positive definition of research-creation is found in chapter 3: "Research-creation is understood as an approach applied to an individual or multiple-agent project combining research methods and creative practices within a dynamic frame of causal interaction (that is, each having a direct influence on the other), and leading to both scholarly and artefactual productions (be they artistic or otherwise)" (p. 123).

Given these strong arguments for acknowledging the differences between artistic and academic processes and outcomes, how the two should come together in a single project remains somewhat unclear. This is the most significant weakness in the monograph; more case studies and examples would have helped illustrate the key issues that the authors are trying to clarify. It is only toward the end of chapter 3 s that the authors briefly describe a project involving Inuk artist Tanya Tagaq, which, at the time of writing, was still in-progress. This project appears to be their most ambitious undertaking to date, one that fuses art, research, technical innovation, and even engages Tagaq's audiences in the process. They use it as a way of illustrating some of the challenges that researchcreation poses and difficulties that can arise in collaborative relationships. Although this is an interesting and helpful example, it is unfortunately the only one they provide. Understandably, they want to present their most recent work; however, in the earlier French-language version, they provide several examples of successful research-creation projects, including one that produced Tagaq's award-winning album Animism (2014), which helps the reader understand how their concepts work in practice. It would have been helpful to have included these in the English version.

It is impossible to summarize in a short review the many timely and important topics that Stévance and Lacasse address in this book. The translation of this critically important text is a valuable contribution that brings this conversation to an English-speaking readership. It is especially relevant for those working in fine and performing arts departments; however, larger discussions about the changing role of the university under neoliberalism and ongoing epistemological debates between disciplines will be of interest to a wide range of scholars. While their examples and analyses are drawn from the Quebec context, their contribution to these epistemological debates has much broader relevance. This is likely to remain one of the most comprehensive and crucial texts on research-creation. 


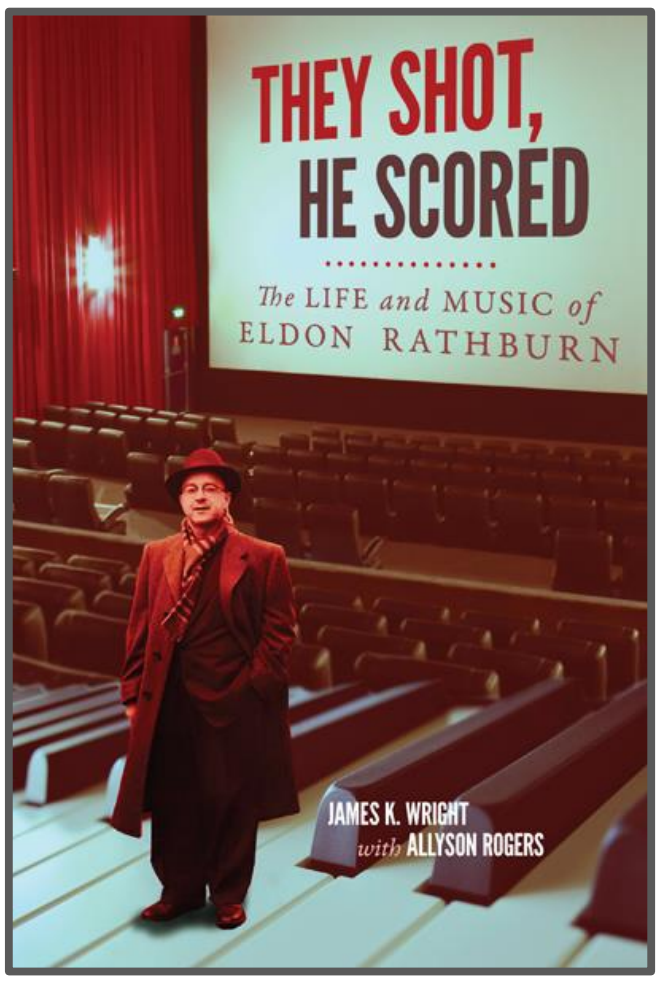

They Shot, He Scored: The Life and Music of Eldon Rathburn. By James K. Wright. Montreal, QC; Kingston, ON: McGill-Queen's University Press, 2019. 362 pp. ISBN 9780773557154.

https://www.mqup.ca/they-shot--he-scored-products9780773557154.php

Reviewed by: Michael Pinsonneault, Concordia University

In composer Miklós Rózsa's autobiography, Double Life, an oft-quoted anecdote about Heitor Villa-Lobos and the 1959 Hollywood film Green Mansions is amusingly told. The Brazilian maestro had been given a Portuguese translation of the script at an early stage of production, and used it as if writing an opera or ballet, arriving in Los Angeles with a complex completed score that he handed to the music department at MGM. "But Maestro," Rózsa asked when he was shown the score, "what will happen if your music doesn't match the picture exactly?" Villa-Lobos, obviously talking to a complete idiot, replied, "In that case, of course, they will adjust the picture." A few days later, he was politely paid his fee and sent back to Brazil so that Bronislau Kaper, an experienced MGM staff composer, could fit his music to the visuals as best he could.

The history of concert composers who have written for the cinema indicates that Villa-Lobos is emblematic of a particular profile-the difficult fit. But Rózsa himself represented quite another profile: a three-time Oscar winner with nearly 100 feature film scores to his credit, he maintained a devotion to concert music composition throughout his career, and had a clause in his contract with MGM that allowed him three months of the year to work exclusively on it.

With the publication of James K. Wright's biography, They Shot, He Scored, readers have the opportunity to learn about a Rózsa-like figure in Canadian film, Eldon Rathburn. A rough contemporary of Rózsa (born eight years after him in 1916), Rathburn had varied musical interests from the outset. He began composing for orchestra while still in his teens and won several major awards for his classical work before turning thirty (including first prize in the L.A. Philharmonic Young Artists' Competition, whose chief adjudicator was Arnold Schoenberg). Wright lists 100 concert compositions in Rathburn's catalogue, written between 1933 and shortly before his death in 2008 and including orchestral as well as chamber pieces. But that significant body of work was the fruit of only one half of Rathburn's "double life." While pursuing conservatory studies in composition and piano in Saint John, New Brunswick, in the

This work is licensed under a Creative Commons Attribution-NonCommercial 4.0 International License. 
late 1920s, other dimensions of his creative expression began to emerge. Both continued to evolve in more or less simultaneous fashion over the course of his long career, running on parallel tracks of equal magnitude and importance.

Rathburn's principal musical mentor at the time was William Bowden, who worked regularly as an accompanist, arranger and conductor at Saint John's newly opened Imperial Theatre, a venue with a fourteen-piece orchestra. The young Rathburn became fascinated by the musical accompaniment for silent film. A regular attendee at his teacher's engagements, he was able to study cue sheets and closely observe the craft of the silent film accompanist-composer-arranger-conductor before the talkies made those roles obsolete in the early 1930s. And during that same early period, Rathburn was recruited for his piano playing skills by the legendary Maritime fiddler Don Messer, beginning his professional musical career recording and touring with Messer's New Brunswick Lumberjacks and mastering their repertoire of country reels and jigs, folk songs and popular tunes. Both of these lines of musical development would deeply inform Rathburn's compositional pursuits over the coming years, baking a core eclecticism into his modus operandi, as it were.

And so it was that when Rathburn accepted a staff composer position at the National Film Board in 1945 , he brought a multi-faceted approach to the movies that he scored. These totaled nearly 250 over the 50 years he was associated with the Board and included outstanding collaborations with legendary NFB animation department head Norman McLaren (e.g. Short and Suite, 1959). In 1960, he collaborated on Universe, the multiple award-winning educational documentary about planetary science that caught the attention of American filmmaker Stanley Kubrick as he was preparing for his space epic, 2001: A Space Odyssey.

Wright does a commendable job of chronicling this best-known part of Rathburn's career, providing some fascinating accounts of the similarities and differences between Canadian and Hollywood production approaches to the soundtrack during and after the "classical" studio period that wound down during the 1950s. He also gives detailed descriptions of Rathburn's more unusual projects, including his music for the multi-faceted Labyrinth installation at Expo 67, and the soundtracks he composed for various IMAX features in the 1980s and '90s.

Further to Wright's credit (and in spite of the somewhat misleading title of his book), the other half of Rathburn's "double life'" receives equal attention. Extensive chapters are dedicated to his concert music, to the idiosyncratic works he created for unusual instruments such as the banjo, calliope and other historical keyboards, as well as to the encounters Rathburn had with various luminaries of 20thcentury music (including Schoenberg, Varèse, Ives, and Virgil Thomson) and the specialized repertoire he created that was dedicated to his lifelong fascination with trains.

Wright's biography features fifty-six figures, including score excerpts, archival photographs and memorabilia from Rathburn's estate, and extensive appendices (a filmography, lists of works, and a discography). Cutting across Canadian biography, film studies and musicology, They Shot, He Scored is both a welcome contribution to scholarly research and an entertaining read for a more general audience. 